SAND77.0001

Unlimited Relevese

UC.7t

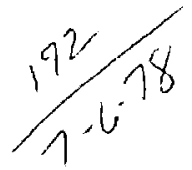

Dr. 230

\title{
Severities of Transportation Accidents Involving Larya Packages
}

Albert W. Dennis, Jaremiah T. Folury, Jr., William F. Hartman, Dost W. Larson

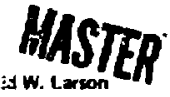

;
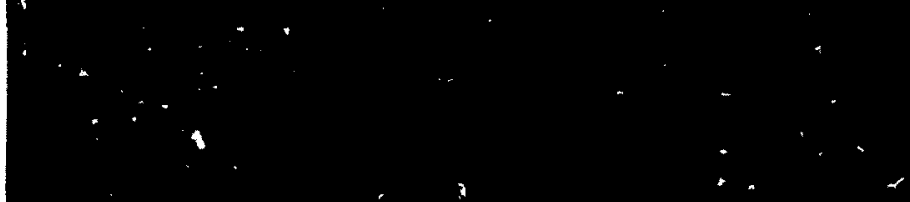

3

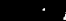

$\mathbf{t}$

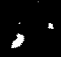


Issued by Sundia Laboratories operated for the Unired States Department of Energy by Sandia Corporation.

\section{NOTICE}

This report was prepased as an accauni of work sponsored by the United States Government. Neither the United States nor the United States Depurtment of Energy, nor any of their employees, nor any of their Loritraciols, subcontractors, or their employess, makes any warranty, exptess or implied, or ensumes pny legut lisbility or esponsibitity for the accuracy. complezeness or usolulness of any inlormation, apparatus, :roduct or process disclosed, or represents thas its use would not intringe privately owned rights.

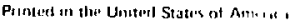

Awaibisle from

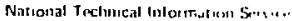

U. S. Depurtmetrl of Commerces

5285 Pont Royal Roal

Springlicld, VA 22161

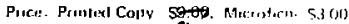

$8, \infty$ 
SAXDTT-000t

1 minriod Relés

Hrinted $11, \cdots 1 \% \mathrm{t}$

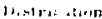

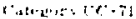

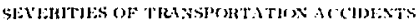

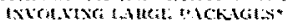

\author{
Alb:12 14. 1) 16:12

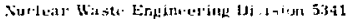 \\ Jereniah I. Foley, 15. \\ Wiliam f. Hartman

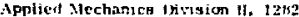

lavit W. Larion

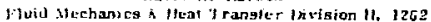

Sindia i.aboratorteg

Albuquerque, trw Mexico $\$ 71$ H5

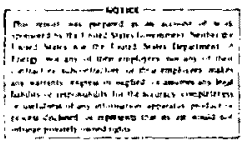

AtSSTRCT

The atunormal enviroutrucnts to vlich a large package-for example, a spent reactor fuel shjpping cask - may be swijected during lind transportation are defined quantitatively. The material presented should provide one component required in the efaluation of risks assaclated with the shiprent of hazarcious malcrials, In Part I the study results are summarized: in fart tl the physical parameter of truck transport accidents are discussed; and in Part III the physical parameters of train transport accidents are examlned.

\footnotetext{
This work was gponsored by the DOE Diviston of Environmental Technolngy.
} 


\section{ACKNOWLEDCMENTS}

The authora gratefully acknowledge the contributiong made to thit abudy by their late colleague, Fichard k. Clarke.

The authorg aloo wish to extend their appreclation to Meagrs. T* G, Priddy, J. T. Black, and C. A. Dardagon for help in the preparation of this repart. 


\section{CONTENTS}

PART : SEVERITIES OF TRANSPORTATION ACCIOENTS-SUMMARY

introduction $1-3$

Ditctssion of Envranments

Discusgion of Results i=6

PART II MOTOR-CARRIER ENWIRONMENTS II-1

Chapter 1 DEFINITIONS AND ACCIDENT ILATES II-3

Aecidem Definition $1 \mathrm{I}-3$

Accidant Rate $11-3$

Accident- Ervironment Definitions II-A

Ifigtorical Data Base II-4 *

Chapter 2 FIRE ENVIRONMENT $11-7$

Introdustion $\quad$ is-7

Data Buse $\quad$ II-

Fro Deserfption II-9

Fire Duration $11-10$

Concluations $11-15$

$\begin{array}{llr}\text { Chapter } 3 & \text { IMPACT ENVIRONMENT } & 11-17\end{array}$

Introduction $\quad[\mathrm{II}-17$

Collusian and Nancolliaton Aceidents $\quad$ II-17

Aralyeis of Truck-Collsion iccidents ii-Is

Enviranmental Degcription $\quad$ II-18

Colliston Accident inpact Configurations U-21

Regulto $\quad$ 11-21

Compusacion of Rateg Agsocisted bith a Given Velocity Change 11-23

Concluaions II-24

Chapter 4 CRUSH ENVIRONMENT $11-25$

Introduction $\quad$ [3-25

Analysts $\quad$ I[-25

Conduglang $\quad$ [1-2]

Chapter 5 IMMERSICN ENVIRONMENT IIm-28

Introduction II-28

Analyeis $\quad$ IL-28

Conclugiong $11-33$ 
Chapter 6 PUNCTURE ENULRONMENT

Introductlon

II-34

Pancture Thrent

4I:-34

Probablity of Puncture

$\mid \mathbf{1}-\mathbf{3 1}$

Canclaston:

II +35

$11+35$

\section{FART III TRAIN ENIRONMENTS}

III-1

Chapter 1 DEFINITIONS AND ACCIDENI RATES

IIII-3

Accldent Deflnituon:

II-3

Accident Rate

[It-3

Accldent Exviranresni Delluitione

IIt-4

Chapter 2 FUE ENVGROXMENT

IIt:-6

Introductuon

III-6

Data Bage

III-?

Flce Degcription

IIt -9

Fire Duration

III -0

Conclusiong

$11+14$

Chapter 3 IMPACT ENVRONMENT

IIt-16

Introduction

1) -16

Derallment Analysig

III -16

Colligion Anelyais

III -20

Oher Train Aceddents

IIt $-\mathbf{2 2}$

Trafn-Aceident Analysig

III $\div 22$

Coneluatons

III-23

Chapter 4 CRUSH ENVIRONMENT

f t $=25$

Introinction

$1.1+25$

Crueh Description

III -25

Frequency of staule Crush

III -25

Cruah Severftlea

11-31

Conclualons

III -32

Chapter 5 IMAEREION ENVIRONNENT

1I] 35

Introduction

II $=35$

Immerston Probabiluy Model

U1 -35

Depth Probabillty Mode1.

Concluatons

II) $-\mathbf{3 7}$

II $m 38$

111 -39

Chopter 6 PUNCTURE ENVTONMENT

III -39

Introduction

III -40

Puncture Resistance

III $-\mathbf{4 1}$

Probabnity of Puncture

II) -4

Equlvalent Wall Thicksesa

III-48

Summary of Reaults

III -49 


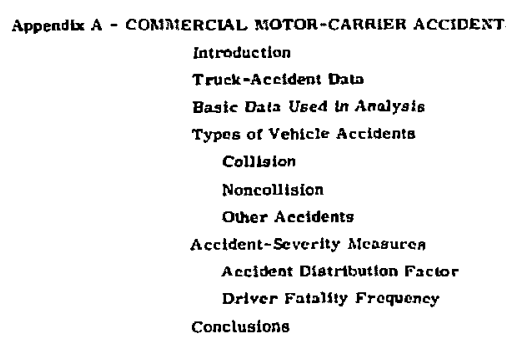

Appendix B - MOTOR-CARRIER ACCIDENT DISTRIBUTIONS
Introduction
Truck / Truck and Truek/Auto Aceidont Distribution
Truek/Train A ceident Dtatribution
Dietrlbotion of all Truck Accidents for Analysis

APpendix C - MOTOR VEIRCLE AND TAAIN SPEED DISTPIDUTIONS FOA MOTOR-CARRIGR ACCIDTNTS

Motor Vehicle Speed Distributions

Train Speed Distribution

APPENIL D - WEIGHT OLSTRIUTIONS FOR MOTOR CARRIERS IMUOLVED IN ACCIDENTS

Motor Vehicle Weight Distribution

introduction

Passenger Autog; Plckup and Panel Trucks

Trucke

Train Weight Distribution

Object Weight DLatribution

Appendlx E - TRATN ACCIDENTS

Frequeneles or Train-A ccftent Types

Net Velocity DLatributiana

Typical Train Deflnition

Accident Ante per Car Mile

Preaccident Train Speed

Car-Derallmeat Modols

Car-Colliston Models

Tratn-Length Effect

E흐로

$A-1$

A -3

A -3

$A-1$

A -5

$A-5$

$A=5$

$A-6$

$A \sim B$

$A-6$

A -7

$A=9$

$\boldsymbol{B}-\boldsymbol{1}$

A-3

$\mathrm{B}-3$

B-6

B-6

C-1

C-3

C- 6

D-1

D-3

D-3

D- 4

D-5

D-ค

D-6

E- 1

E-3

E-4

E-6

E-:

E-?

E-10

E-13

E-14

AppendtI F - REFERENCES
F-1 


\section{ILLUSTRATIONS}

Figure

Foge

PתRT 1

I-1 Expected frequency af occurrence per hlllion iransport miles of a fire exceeding a guven duration.

J-7

i-3 Expected range in frequency of occurence of an impsct-caused velocity shange greater than or equal to the velocity change showa.

$1-7$

PART [1

11-1 Probablity distribution of truck-accident fre temperatures.

I1 $-\mathbf{0}$

II-2 Simplutied flow chare of Monte Carlo Itre-turation program.

1I-11

II-3 Cumulative diatribution of firemacedent duration for truck trangport of large Aackagea.

II-4 Probability per truck mile of fire exceeding a given duratum.

I1-16

II-5 Impact velocity change os a function of cumulative frequency of occurrence for highway transportation.

I $1-22$

11-6 Veloclty change due to impact in a highway trangportation colligion accident.

II -22

1I-7 Renm-nalysis loadtng configurations.

11-8 Probabllity or package being Immerued in a depth greater than Jepth given for bridge accigonis.

II-29

11-9 Probabluty of package beting immer given for ditch accidents.

$[1-30$

1I-10 Probabllity of package belng immerecd in a depth greater thin depth given for munoff acefaents.

11-11 Probabltity of immersion at a depth greater than that ahown. Etven immergitan.

11-12 Probablity, per mlle, of immeraion in a depth greater than depth given in a motar-carrier accident.

II-32

\section{PART III}

III-1 Simplifled Mow chart of Monte Carlo traln-fire-duratlog program.

III-2 Duration probabluty of train-fire aceidents lovolving dirge packages.

11- 13

wi-3 Notribution of property damage from rallroad fres.

ID- 14

17-4 Prababulty per car mfle that a flre will occur and exceed the duration ghown for train accidente.

IIT- 15

ID-5 Car impact factor.

III- 17 


\section{nL.LUSTRations (cont)}

III-B Severity of accident factor*

[II*IB

LI-7 Tratn derailment aceiderts.

III -19

III-B Train caljision accidenta.

[1] -22

III-9 Tratn accidents, all types.

IU-24

III-10 Average number of cers derailed verous gpeed at the ume of deratlment accident.

$111-26$

11-11 Average number of cara and locomotives deraticd per train in a collision that producey derallment ag c funclion of net collioion speed.

111-12 Beam configurattong and contabner location density funcuong for crush typee.

$11-33$

d1-13 Cumulative $F$ distritrutions for types of crush.

$111-34$

III-14 Cumulative distribution of toral crush load.

1 II -34

I11-15 Bridge and river.

III-37

III-16 Cumulative probability according to immeraion depth.

UI-17 Probability, per car milc of beline immersed at a depth greater then that shown.

III-18 Astumed probabillty density functions for fallure threshold velocity of train car couplers impacting magsive nomperforating tarects.

1D-19 Coupler overtide, tank car colliston.

III-20 Coupler overtde. package car.

\section{APPENDD A}

A-1 Normallzed driver fatallty ratio.

A-2 Normallzed driver injury ratio.

A-10

A-3 Normalized accitent cost ratio.

A-4 Normallzed driver fotality ratio for revised accident types.

A-5 Nomalled deiver tnjury ratio tor rovised accident types.

A-6 Normalized acerdent cost ratio for revised aecidest types.

A-7 Accident trequency by revized accldent typee. 
APPENDDK C

C-1 Vehicle accident speed distribution.

$C+3$

C-1 Vohicle-aceldent epped digtribution used in the andyois.

C.S

C-3 Train/vehtcle grade-croasting aceldent data, gring speed of traln at lwe of accident Ifrom 1060-1972 FTA Rall-Highwy Accident Data - 9190 pccidents).

$C=7$

C-4 Rallroad train specd detilbiston uasd in gradenerossing analyela.

$c-8$

\section{APREADD E}

E-1 Ciags 1 trelght-train accident ratce and frequencics.

E-2 Cumulative distribution of freight train speeds far colligition accidents.

$\mathbf{E}+\mathbf{8}$

E-3 Cumulative diatribution of freight traln apeeds for deraliment accidente.

$\mathbf{E}-\mathbf{9}$

E-4 Diatrbution of traln epceda at kimes of break. brot en-trath accidente.

$\boldsymbol{E}-9$

E-5 Average number of cars deralfed as a funcuton of traln epecd at time of derntiment (Model 1 ).

E-11

E-B Average number of ears detailed as a function of tratn speed at time of derailment (Model 2 ).

$E-11$

E-7 Average number of carg damaged per aceldent (Model 3).

E-12

E-8 Comparison of Deratlment Models 1, 2, and 3.

$E-12$

E-9 Aceldenta tnvolving colliginn of any kind (Model 2).

E-10 Probablity that a goven ear is derafled, gtwen that the traln consiats of $\mathbf{N}$ cars, three locomotives, and a caboose. 
TAB31.t3

Table

Hate

pant II

$-I$

$-11$

$-111$

$-I V$

$+1$

$-11$

FAIT IE

$-1$

$-11$

$-t$

$-3 \mathrm{~V}$

$-r$

$-\mathrm{rit}$

-VT

- vIII

$-1 K$

$-x$

$-X I$

$-x I r$

$-x$ tII

-xIV

$-X V$

-XVI itecldent Pates

$11+3$

$\therefore$ : 1 .

11-:

Trük Aceiden: Dow

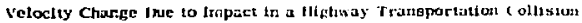
Aceident

$11-23$

II - .5:

$11-3$

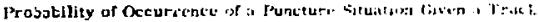

Transport Colliglan treicient

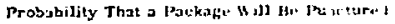

$|2|-3$

$111-3$

III- $\mathrm{E}$

(1)- 1"

III- 2]

11) - 23

$111-20$

III-30

II:-31

It: 16

[11-4:5

III - 1

| II -45

II)-iti

IIt 1 :

[IT-1!

A-t Summary of Atoving Vehlcle Accidents, 1969-1472 is.tcs Repors

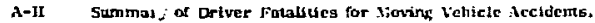
1969-1972 BNICS Reportp

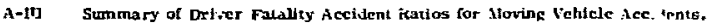
1969-1072 Bitcs Reports

A-IV Summary of O-iver Fatality and Aceident Cost Ratios for Mlovine vehtele Acelderts, $1969-1012$ Ghtc's Rrpars 
TA Ifs risi (cont)

Tallir

Itre

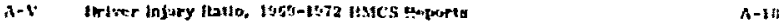

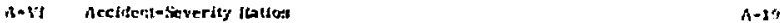

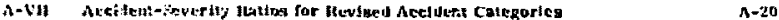

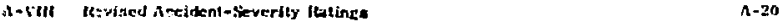

Alvitring is

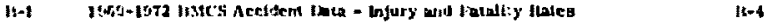

|f-1| kicurkent ingtribution factora is-5

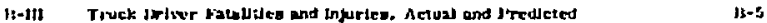

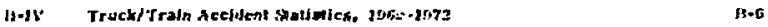

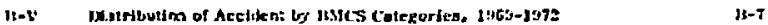

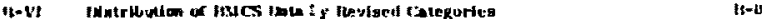

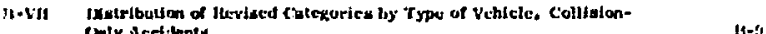

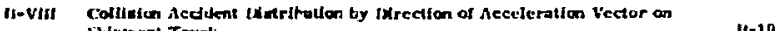

siltwitiont Trusk $\quad$ It=10

A IPISHax 6

c:-1 Vebicle-Aceident Spect Ixutributiong

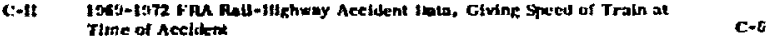

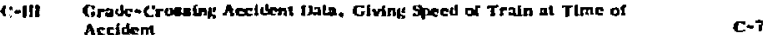

A Iy-14: t)

Int Notor Vehicle siatiotics, 1972 Jj-3

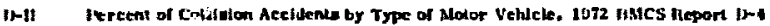

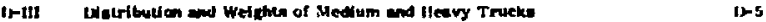

Int5 Fretpency of Geeurnence of Object callalon by Group lased Vinon

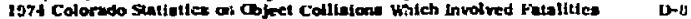

Afrometr:

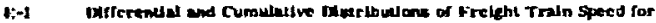
follision Aceidente

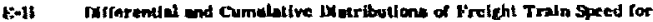
Iheralinent Aecidente

E-5

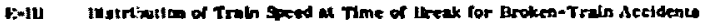

E-6

B-1V Defintion of Typical Freight Train as Uaed in Thla Sudy

E-7 


\section{PART I}

SEVERITIES OF TRANSPORTATION ACCIDENTS-SUMMARY 


\title{
SEVERITIES OF TRANSFORIATION ACCIOENTS - SUMMARY
}

\author{
Intraduction
}

This atudy was undertaken to Jefinc in a guantitative nenjudgmental techrical mannter the

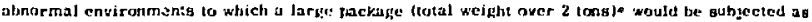
the result of a trunsportation occitem. ILecauge of the pockage welght, alr ahtipment was not congidered as a normal trasportation mode and was not inciuded in vie atudy. The abormal

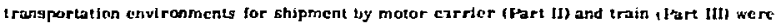
determincu and quntilicd. In ull cance the mackege was asaumed to be transported on an open flat-hud iruck o" an open flat "bed rallear. In an carber Btudy. 2 refersed to in this report as S1 A-74-0001, the ginall-packnge environments were investigated. The primary purptase of

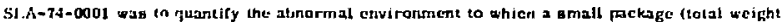

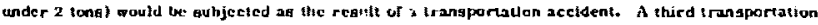
atudy, related to the abnormal environment involving wateryoys rangfortation, is now woer wayt

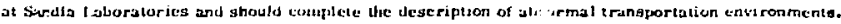

Five abnormal ehvironments were derined anri investigalew:
1. Fire
2. Impact
3. Crush
4. Immergion
5. Puncture

The primary interess of this study was directed toward the type of Iarge package used to tronaport radicactive matcrials; however, the findings are noi umited to thit type of package but can be applied to a much larger class of matertal shipping containers.

This report is not intended to kg an evaluation of current radioactive matertal shipping practices, package degign. or requlatory atandards it is intended. rather, to scrve as

\footnotetext{
"Units of measare in thls report are expressed according to the English gravtiational syotem becaupe (1) the document is a companies to SLA-74-D0Ot. Which uses Engllah units and (2) date in this doeumbot wil be compared with Federal regolatory standorda (e.g., 10-CFR-71), which uses bigliah unies.
} 
one of the pru:cjpal steps In detersining the rlak to the public associated with the Land Iransporta-

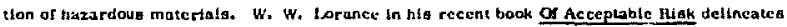
tite basic elements of a rigk esaluation as followg:

1. Define the contitions of exposure

2. Identify the adi $\cdots$ ac offects

3. Rekete expoesre with effect

4. Eotimate overall riak

This report provides one of the varibhles necessary to define the condition of cuposure for large ahpplng conlaincrs; namely, a techulesl deseription of the land transportation accident envionment. Other varlables that must be congidered include the response of the package to the accident conditions (damage). the quantity of hozardous material released (if an;'). the radius of effect of any releate. the number or people exponed to the hazard due to any release. and the intenalty of expasurc. A detalled definition of exposure would entajl these and other factors; hence, it fa not fcagible to attempt to egtabitah package specifications solely on the basia of the Intormation contatned in this report.

\section{Discussion of Environments}

The description of abnormal trangportation environments is complicated because the experimental datn. auch as thoge uged for the detalled deacription of normal traneportation environments, is not avalable. The enviranmental degcripuons found to be sultable for abnormal environments are:

\section{Fire}

The optimum description of the abnormal themal eivirimment would be a ect of temperature/ time profles in which each profile woutd have an as:ocklated probability of occurrence and a known lower-bound confidence level. The thermal enviromnental information containted in the report ia divded into two regimes. The firat is the cxpceted fire-temperature regime, the becond is the expected fire-duration regime. Neither of these regimeg could be deflned if this atudy were limited to only publlahed accident data. Consequently, th both regimea, easumptions baned on Informaton gamered from nongceident-related gources were required for obtaining the anvironmental degcrfptions. A though thle may at tirat pppear to be a serious shortcoming. It does not preclude an acceptable prediction of the Ite threat. To apply the information to apeafic paskago, one mut be able to identify those thermal environments that may regulk in an undeafrable reaponse of the material contained in the package. The rire-temperature distributian and the fire-duration distribution piesented in Parts 4 and III of thif: .eport can then be used to estimate the copected frequency of situations that may be of concern. 


\section{Impect}

The degeription of the impact environment. Like thi: of the fire environment, is not optima. Ideally, the reader would be presented with a bet of shock pulges defined by lat the ahape or the shock pulse (c.8.. ocuare wave, triangular pulach, (b) the amplitude in terms of acceleration unta, and (c) the polne duration. Ench of these pisigeg would be accompanled by an expected probablifty of oceurrence and lower-bound confidence levti, Jealistically, ore can never expect the information necessary for establiahing this type of description to bc available from the historled accldent recorda.

The velocity uange that the shipment vehiclis is expected to experience can be conscrvauvely calculated if it is baged in the principle of Conservation of Momentum and edsting aceident records. The reader ahould note that the value of the velocity change that the vahlele experiencen is actually the value of Ute Integral of the acceleration Ume hibtory-the ahock 1 slae - applicu to the Bysiem by the impact. For any particular system the total mass of the loaded shipment vehicle is known and the expected fraction of accidents in which a given veloclty change will be exceeded can be determined from Parts II and III. If the pulse is to be completely detined, Ite characteristice may be determined anslyifically.

Two governing force levels mugt be congidered in any analyals: the minimum rarce leve] necessary to produce an undesired consequence, as determined by capabiltites of the ahipment syatem, and the inadmum force level that the target can suatain. If a cjess of targets is not capable of eustoining this minimum force level, these targets and all 1esser thrgets should be climinated from consideration. For example, in the motor-carfler emriranment, If passenger autos and all jeaser targets (from Foreo-ievel consideratons) are excluded, over eo percent of All motor-carrier callsion actients become relatively unimportant. If anly moselv atatsonary objects and raluroad traing are found to challenge the iransport system, almogt 99 pereent of all motor-carrier collibion accidents can le cxcluded from consideration. Because of the inability to prejudge what atrength capabiliues the tranaportat $=$ systems rray poseeas, the complete impact parameter distribitlons are preaented in the Appendix to this report.

Crunh

The erusb environment is one that rrequendy occurs in aecident aitiations, but ia normally not aingled out as signicant enough to merit reporting. The data ured in this report relating to the crubh environment hag been isferred from accident reporls containing photographs of or line drawings of accldents scencs. Addfticnnlly, conservalive ageumptions thit are in agreement with the kown phyweal parametars of cruah situatlons have been utilled to predict the expected ciush loading: 


\section{Immeralon}

Becauge immergien ia a very infrequent enviranment, no accident reports that spocfifed the depth of the immergion vere found. Evaluation of this cnvironmental scverity was based salely cn the frequancy of occurrence of waler hazards and the expected depih profile associated with incse hazards.

Puncture

The threat of puлcture fo directly relate-t to package construction. Consequently, to obtaln a mensure of the threat of puncture, it li nectasaly to asbume bagic pachogc construction reatures. Mest atudles of the mechanica of puncture are cmplrical, and are applicable only to balliatle* (2 to 3 times sonle velocity) or higher-veloclty projectiles. In this much lower region of interest, the begt that can be done in the general situation if to obtain an-ordet-ol-mugnltude esumate of the wkelhood of puneture, given an aceldent. This has been dane, and the reguts are presented in terms of the equivalent mild-otecl package wall thickenegs. The puncture environment is di6cusged in detall in Part IIl of this roport and fo correlated with recordet railrond tank car puncture accident reports.

\section{Di :تusssion of Results}

The results of this study are presented in a seres of praphs and tables that describe the copected anvirconmental levels that a package or eystem may experience as the result of a land transportatim accldent. Figureg I- 1 and i-2 a re examples of these results stated in terms of the expected number of occurrences at a givan level for each ane-billon ghpment inucb, Figure i-s deals with expected fire environment, and Ffgure 1-2 depiets the expected impac, environment.

The response of the item being ohipped to the environment imposed on the shipmisit, rather than the enviranmonts themselves, determines the significance of the environnent. For examplr. if immerala whl cruse an unzeceptoble reaponse of the material being ohipped (c. 5.. nuclear criticality), it if en environment of primary congequence. If, however, immerston will not reoult in an unacceptable regponse. regardlegs of depth, then immerafon ts obviousty of little cancern. Simlar statements may be made about cach of the other four environments considered.

If one proceeds from the lcast complex to the most complex environmental descriplion, the reaults of this study may be cummarized as follows.

\section{Immergion}

This environment is characterized by the probabllity of the package being immeracd to a depth leas than or equal to a glven depth. 


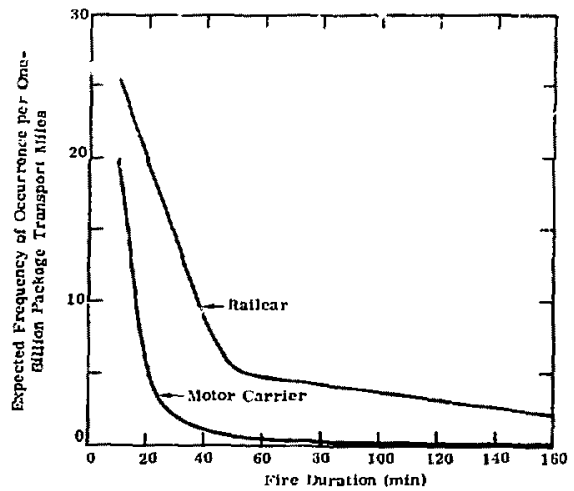

Figut 1-1. Expected frequency of oceurrenec per biltion trangport miles of a firc exceding a glven duration.

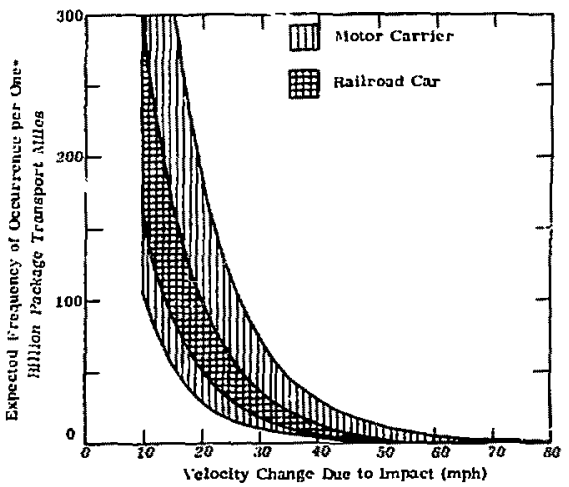

Figure 1-2. Expected range in (requency of occurrence of an impact-caused velocily change areater than or equal to the velocity change shown 
Crugh

This environment ls charactertzed by the prabability of the toul erush lozdirg being equal to ar less than a given thtal load.

\section{Punchure}

This environment is characterixed by the probability of puncture as a fuiction of package wall thickne日s.

Fre

This enviroment is characterl.ed by two probability deseripisons: the expectid firetemperature distributon and the expected fire furaton. The res'sz muet determins thoge temperature/time profiled that may cause an usaccptnble aystem gesponse. Given this information and the fire-temperature and tlre-duration probahilties, an eatimate can be made of the probsbility of the temperature/time profiles occurring in aceident aftuations.

\section{Impret}

The evaluation of this environment requlres a knowledge of the complete ghipment gystem (t.c., the ahfment vehiclel, the tieciwn system. the package, and the material shipped. The enviroment is chasacterized by the expected system velocity change resulting from the most gevere single impact experienced in a collialon accident. For example, conslder a rear-end truck/truck collision whire the ghipment truck traveling at 55 mph overtake and collideg with s secand truck. Ouring the impact the shipment truck is alowed from $55 \mathrm{mph}$ to $25 \mathrm{mph}$. It then proceedg along the ghoulder of the highway and comes to rest. A 30 -mph velocity change would be recorded for this aceident.

Velocity change was chooen to characterize the impact envronment becauge it (1) Lo a quantity that to understandable to most readers and (2) will gencrally provide a conservatuve damage estimate if a masive, essertially unyiclding target is assumed and the velocity change value is used as the tmpact velocity. The transport vehicle atructure, the package tiedown aygtern, and the target impacted will all afiect the severity of the impact environment. Extersive data stunstarteg are included in the appendix of this report to ajd the gerious investigator in determining those impact environmetts that may be of cancern and to obtain a reascomable eatimate of the probabllity of occurrence of each. 
PART II

MOTOR-CARRIER ENVIRONMENTS

I-2, 2 


\section{Chapter 1}

\section{DEFINITIONS AND ACCIDENT RATES}

\section{Accident Definition}

The defintion of "accident" as used in fart $\mathrm{I}$ is congletent with the definition for Classes I and II Interstate Motor Carrlers of property as set up by the I3urcau of Motor Carrier Safety. Federal lighway Adminfetration, U. S. Department of Trangportation. For consigtency with 5IA-74-0001. this definition. Hitich incluics all accidenta that result in fatalitics. fajurica. or property damage of $\$ 250$ or mare, ${ }^{2-6}$ has been retained for the current study-

\section{Accident Rate}

Aceident ratis in accordance with the above aceident definition are reported annually ${ }^{4-6}$ for interefty shipments by CIasses I and II interstate Motor Carricrs of Property (Table 11-]).

TAHL.E II-I

Accident Rates

\begin{tabular}{ll} 
Year & Aceldent Rate (accidents per mile) \\
\cline { 2 - 2 } 1066 & $2.4 \times 10^{-6}$ \\
1967 & $2.4 \times 10^{-6}$ \\
1068 & $2.5 \times 10^{-6}$ \\
1969 & $2.4 \times 10^{-6}$ \\
1970 & $2.7 \times 10^{-6}$ \\
1971 & $2.2 \times 10^{-6}$ \\
1072 & $2.3 \times 10^{-6}$
\end{tabular}

No attempt is made in this study to define a rigorous acedent rate statiatically. Rather. selection of a representative rate is subject to the constraint that (1) the rate, (2) the accident delinition, and ( 3 ) the environment probabilities-given an aceident-are consistent. The rate selected for thif gtudy is

$$
i c=2.5 \times 10^{-6} \text { accidents per mile. }
$$




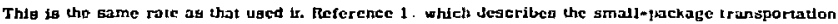
envtronment. Here, the ratc equala the probubibiv of a truck accldent ior 1 nille of travel.

\section{Accident Enviro. 'ment Definitions}

Interactlons between a whipping container and the rurroundings during an accident as " labeled "aceicient envionments." The live accident envilanmente are definea bolow. The torms "fire."

"impact." "erush," "piricuse, " and "Immersion" ave nat to be interpreted by their diclionary meaninge, but rather accnrJing to the gpectilc defirstions given below.

\section{Accident Emviranments}

Dim. Subjection to a high-Lemperature enviranment produced by combualion. Example: The interactios of a contalner with a fire following an overturn.

Impact. Striking or belng atruck by an abject that has no sharp projeclione. Example: Colltaion with a highwy overpass bridge piet.

Crugh. Subjection to structural loads that may be cither highly localized or apanditis a large area of the contalner but that connol be categorlzed as impact, puncture, or immersion. Example: The interaction of a container with the ground when the container regte between the trafler and Eround alter an aceident.

Puncture. Striking or belng at ruck by an objoct that has a potential for penctrating the canblier. Eampic: The impalcment of a conlaincr on 3 alrucura! member of the truck.

Immereton. Submergion in a liquid medium. Example: The interaction of a cantalner aith water after the truck plunges off a bridge into a river.

\section{Historical Data Base}

The data bage csed in this study to determije accident frequency of occurrence by type of accident was prepared by the Bureau of Motor Carrier Safety, Federal Ilighway Adminigtration. U. S. Depertment of Transportation, 2-6 This bureau iseues an annual report entitled Actidente of Large Motor Cerrien of Property. This report is a compllatian of individual reporta by inter state motor carriect baving anual operating revenues of $\$ 300,000$ or more. The日e carriers are gubfect to the Federal Motor Carrier Safety Regulations (Code of Federal Fegulatlcns, Tite 49. Parts 390 to 397) anc report as requed by these regulations. A reportable acdient for the selected study perlod (1869 through 1972), as defined by theye regulations, to an aceldent resulung in a fatality. an tnjary, or property dumage of $\$ 50$ or more. Although more recent atatistical 


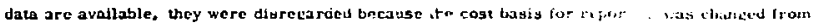

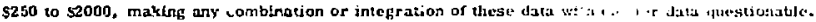

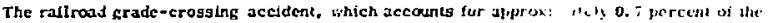

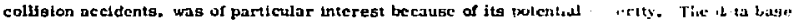

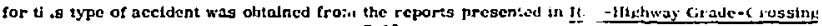

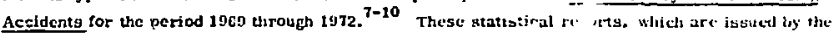
offec of Safety. Fedcral Rallroad AJministration, Jepartment of '1 rensportalson, are bastet ujon

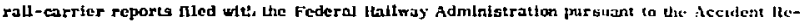
porta Act of 2010 las amended).

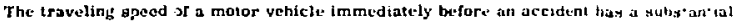
effect upon the severity o: the aceident. Linfortunalely. preaccident vefick speret is not reporte.t

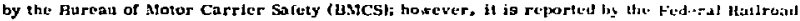
Adminigtration (FRA) bokh for the traiss and for the motor vehicles iltyol ed in grade crosting

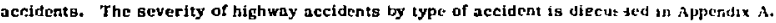

Appendix $B$ or thls report contalns a detailed descriftion ol the methorls used to ubtall the catimated truck-aceident digtribution by type of accident. The digtribulimi, stated in Toble II-IJ, was used in the anplysis. The accident types identified in Table fl-II a re staled itl a stiorthand notation. The designation 1 refers to the truck of intcrest (the truck trinsportanp the package). The designation 12 refers to the other principal vehicle in tho accident. Tlius. "Hear-atd, ol into 42, trusk 0.0856" would be isterpreted to mean "The truck transportung the pack.t." overtonk and callided with a.other truck in 8.56 percen: of the aceldents."

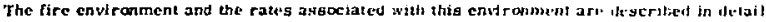
in Chapter $\mathbf{U}-2$ of this report. 
ThIนA: Ji-1!

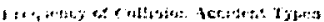

Aretrorst Tyze

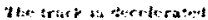

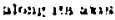

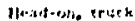

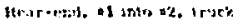

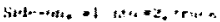

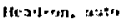

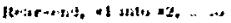

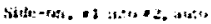

Iturn intes train

Aiject

Suhtetol

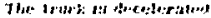

atemp: Hta axts

1tome-1:210, w ints 41 , yruek

fkerie-en-l, al into -1 , suto

SuLADTal

The truck is accelersted fertuchdicular is tis axls

Slde-an, $z$ into 41 . truck

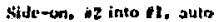

struck by irain
Iremperez

D. 01153

y. $0 \mathrm{irs}, \mathrm{st}$

0., wats

a. 1020

0. 2213

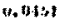

c.coli:

$0.11 ; 0$

U. S. N.
0. Di,OLO

0.1342

0.26 .44
0. 0143

U. $121 !$

0.005

Subtoul

0.14 AH

TOTAL. $\quad 1,000$ 


\title{
Chapter 2
}

\section{FIRE ENVIRONMIENT}

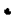

\author{
Introduction
}

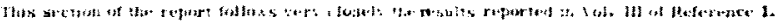

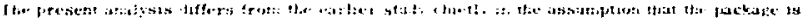

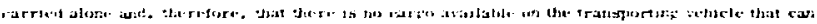

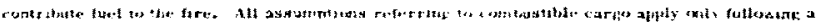

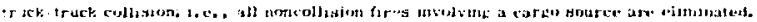

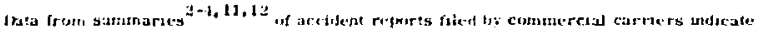

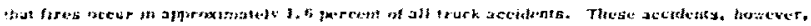

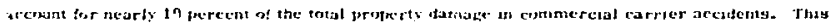

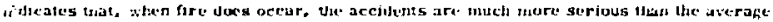

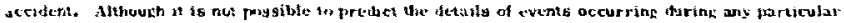

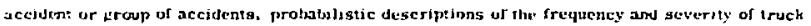

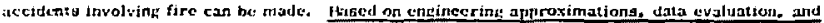
analvical models, reaconable and useful approxtmations of the expected cnvironmental levels are pr\$5sibłe.

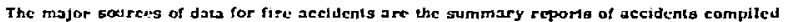

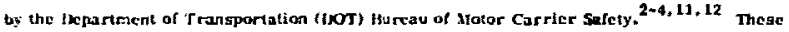
quantilalive data are very complete in terms of aceident type, trequency of tirc, causc of lice, property damage, and other related information. Such information to ugeful in predleting frequency of fires and relatise eeverity (ptopery damage) of accldenta. The reports do not, however, provide the information required for deseriblng ouch erpected cnvtronment levels in a fire acctent as rire oize, intensity (temperaure). location, duration, and combustble materials. Ocezolonaby. the individual accldent reporte of the more ecvere accidents filed by the katianal Transportatian Safesy loar d iNTSB; provide qualiutive caumates of some of the necasary ore paramelerg. in heneral, however, it was necessary to uso vehicle and zecident parameter in conjunction with theorclleal modeling to develog a reasonable deseription of the capected thermal environment.

A truck-fire accident has a large number of variables that affect the reaulant fire. Included among these are fuel cank invalvement, the amount and type of fuel avallable. the find of cargo in 


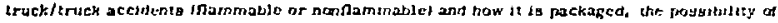

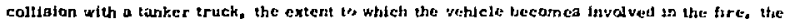
avallabflity of tirefightifg equpmint, and the cfects of all paysible combinations of these and other congiderations, It has not appeared fensible, or even posalule, to develof a rusel wheb

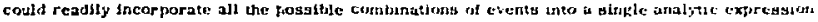

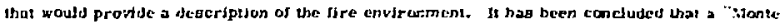

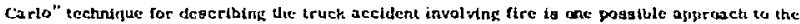
problem of multiple varbabies.

\section{Data Base}

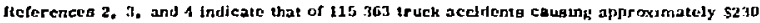

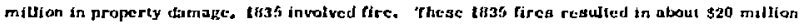
in damage. Approximately 50 percent of the truck accidents involve collision with an auto,

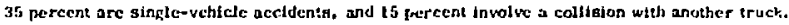
Table $11-$ II showg the relatlve frequeney of varioug types of sceldenes, how often fire occurs in those aceldentg, ansl the pereentape of the tatal fircs accarding to type of aceldent. It is inceresung to note that only about 25 pereent of the fires result from collision-cype acejuents and that ove 75 percent of the fires are caused by flre only and by noncolligion-'ype accidents. These dath are ugeful in determining froruency of 4 res and average property domige per accident. They to not, however, provile any informat'on regarding the accident keverity distribution or the deserlption of the thermal environment. Jeferences 11 anl 12 yield some additional insight into the fire accident by providing data on cauge of ti re. locetion of fire origin. method of cxtinguishment (if any). fuel tank involvement, and broad category deseriplione of the eommodity (cargo) claseffication of the carrter. In adultion. Reference 12 gues bome Indlcation of property damage distribution by showing the property damage that occure for each of verious extinguishment methods.

TABLE :I-10

\begin{tabular}{|c|c|c|c|}
\hline & K Accldent Data & & \\
\hline Accldent Type & $\begin{array}{c}\text { Percent of } \\
\text { Iotel Aceidenes }\end{array}$ & $\begin{array}{c}\text { Frequency of Fire } \\
(\%)\end{array}$ & $\begin{array}{l}\text { Percent of } \\
\text { Totil Firea } \\
\end{array}$ \\
\hline Coludeion wh Auto & 49.7 & 0.3 & 10.4 \\
\hline Collitan wth Truck & 15.0 & 0.8 & 7.8 \\
\hline Colligion with Fixed Object & 14.1 & 0.4 & 3.7 \\
\hline Other Colllalon & 5.1 & 0.9 & 3.0 \\
\hline Ran OAf Road & 7.1 & 1.1 & 4. $\theta$ \\
\hline Oresturna & 2.2 & 1.2 & 2.1 \\
\hline Oher Noncolliston & 6.0 & 13.0 & 48.8 \\
\hline Ero $\mathrm{Orl}_{5}$ & 0.3 & 100.0 & 19.3 \\
\hline Total & 100.0 & - & 100.0 \\
\hline
\end{tabular}




\section{Fire Description}

A truck accitent that resilta it a ire can creatc catgo enw romments ranging feom tessentally

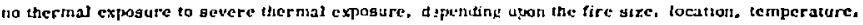
and duration. In adtition to the dicgel fuel or fasolinc ur the fuel tanke, 1ruck fircs car: involve a wite varicty of combustble materials, such as conibustble cargo, cab interior, electrical and brak aystems, and tires.

The expected temperature of the resulting fire will depent upon the cotnitustible malerials involved. It is apparent both from experimental work and from theoretical work that exact predictions of temperatures is any particular fire eannot be inate. Ifowever. Inast hydrocarben rucls - such as Jj-4, dlesel, and gagoline-yield meatured flame temperatures for open burning

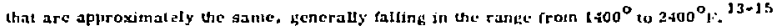
Purthermore, it: Manc temperatures of moat of the other expected curnlustibles fall in that same range, generally toward the lower end. 1 G-17 Therefore, the probabllity distribution of truckaecident fire temperatures can be reasonobly represented by the game distribution determincd in Reference 1. The probability dengity function (pun) is given by

$$
\text { (IT) }=1.77 \times 10^{-5}\left(T-14005^{0.833} c^{-\left(\frac{T-1400}{550}\right)^{1.83}}\right. \text {. }
$$

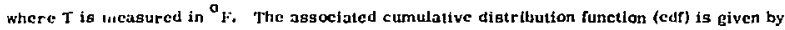

$$
F(T)=\int_{1400}^{T}(T) d T-1=c^{-\left(\frac{T-1400}{550}\right)^{1.83}}
$$

The distributians obtained from Eqs. (II, 1) and (1I. 2) are shown in Figure $\amalg-1$.

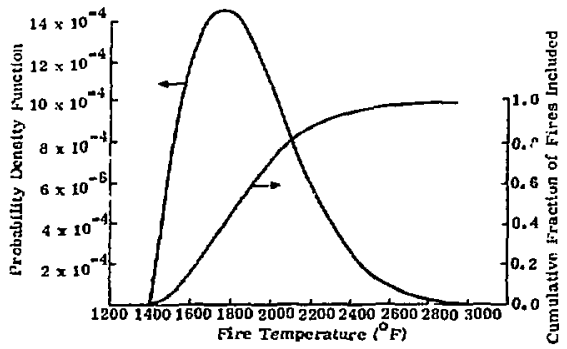

Figure II-1. Probabiuty digtribution or truck-aceldem fire temperaturea. 


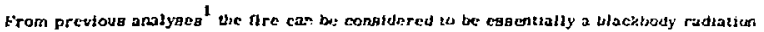
source for a flame thetress of 4 fect or more. For smalker names the elfective emisaivity drops otf very raplaty. The convecuve heat trangter fram the flame to a conbiner conulged in the fire (optically thick) is approximately a factor of 20 lower than the radiative heat 1 ang fer 1 and tierefore can be neglucted in heat trakgler teats or analyses of containers. The aygumpton that the lire radiates ag a bluckbody tends to compeneate tor noglesting the convective trangfer.

A signifient fraction of the fire accjuents presents little thermal threat to the cargo, sinces the II reg are confincd to a amall area, are of ghor duration, or both. The amall local fires are not optically thich, put out a relatsvely small total heat and, unless they spread, a re of minor congequence.

\section{Fire Duration}

Since the avaliable lire-accident data do hot provide quantitative information sufficient for a satistical bagis of fire duration, mouellnk of the expected flre duration had to be bised on various parameters expected to influence the fire and its burn time. The larpe number of viriables Involved and the numeroug comblnators and interactions of these variables precludut a. closed-form deacription of the cxpected fire burn timc; thereforc, a Monte Corlo prediction scheme was used. The model inelutes the avallable data coupled with engineering predictions of fire duratuon baged on probablistie avaikablity of combustiblca from various types of accidents. It congiders the interaction and probabilistic involvement of fuel tanks, thes, car jo, brakes. electrical aystem, and cab os well as the effects of fire-fighting efforts.

A almplitied Bchematle now chart of the computer program ubed to predlet the probability digtribution of fire dirations la ghown in Figure I1-2. Only those aceidents where a fire occurs are simulated in the program; the number of simulated aceidents required to obtain a good atatiatical ontsple ts thereby greaty reduced. From the tnformation shown in Tablo II-1L. the frcauency of fire la known for each type of accident. Random numbers are selected in the various blocks. Decigions are based on the value of cach rantom nimber so that after a large number of buch events the probablity distributans for each event, obtalned either from the data or from modeling. will be followed; a composite or net probability distefbution for the Are duration is obtained by tabulating the results. There is congiderable Interaction between the blocks or Figure II-2; hawever. for aimplicity. ihla interaction is not ahow. For example, the probabllietic involvement of fuel tasks in a fire and the probable amount of fuel avallable to burn a re different for each cype of accident. 


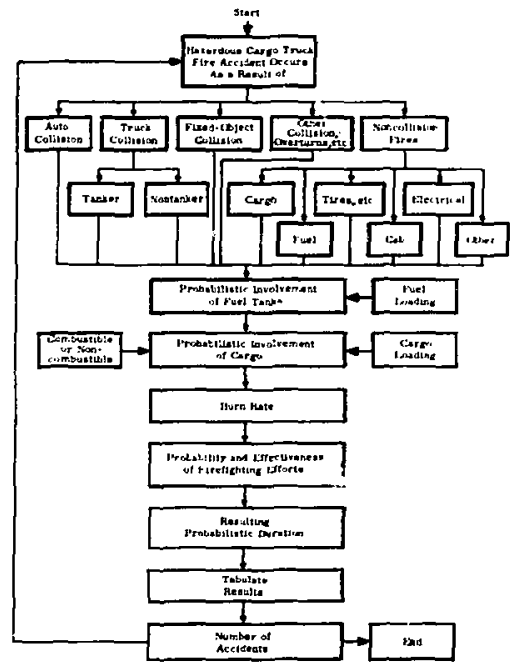

Figure II-2. Simplifted flow chart of Montc Carlo fireduration program.

A llst of the major aseumptions and probability distributions used in the program fnot necessarlly in the sequence used) follows. Where the greatest degree of uncertalnty existe, the iment is $10 \mathrm{crr}$ on the conservative aide (i. c.. to maximize the flre duration). Again II ahould be emphasized that truck cargo agsumptions apply only after' a truck/truck collisfon.

1. Frequency of varloug fre-accident typeg is as ghown in columan 3 or Table II-III.

3. Ninety-ninc percent of the truck cargo weights are between 0 and 20 isns, with an average weight of 10 tons and a cdf of

$$
1 \cdot e^{-\left(\frac{w}{22862}\right)^{2.73}}
$$

where $W$ is eargo weight in pounda. 
3. All tanker truck shipmente are nammable.

4. The fraction (f) of eargo that witt burn, if nammable, can be represented by the diat ation foll)

$$
t=e^{-\left(\frac{r}{0.2 E t}\right)^{1.25}}
$$

which gives an average or exposted value of 20 percent. This distribution was obtained from DOT's OHM dala bank contancr-failure incidents coupled whith a qualtentive review of numeroug indlutdual firo-accidont reporis.

5. If a collision or overturn ftre accident occurs, the fuel tank of one or more of the vehicles is always involved.

5. The fuel avaloble in the fuel tank of a single-vchicle truck accitent vartes from 0 to 200 gallong, with an expected value of 120 gallong and a cdf fiven by

$$
1=a^{-\left(\frac{1}{132}\right)^{3.64}}
$$

where $f_{4}$ Is fuel in gallons. Furthermore, the ruel is distributed uniformly over an area that can vary with uniform probability from 25 to $125 \mathrm{ft}^{2}$. It should be noted in this and all other fuel dispersian area asuumptions that the area is, In general, somewhat lese than the area over which the aceident occure and over wheh yrecknge may be dietributed, The tuet from the fuel tank tends ta be concentrated in and around the fuel tank. Furthermore, the luel tende not to be infformly distribuled, as assumed, but rather forms in puddles in dopressions, gouge marks, gutters, ditches etc. , Or remaing is the fucl tank (or fts wreckage). The senall uniform disperaion area tends to aceount for the fact that the fucl to concentrated near the fuel tank and cornpenates for the fact that the fuel puddles in local areas rather than uniformly over a large area.

T. FuL: avallable In a truck/auto collision varjes from 0 to 250 gallons, with an expected value of $150 \mathrm{~g}$ allona, and the col is given by

$$
1-e^{-\left(\frac{f_{u}}{166}\right)^{3.73}}
$$

The fuel is diatributed uniformly with equal probabillty over an area frodn 25 to $125 \mathrm{rt}^{2}$. 
8. A truck/truck (nontanker) colliston has (uel avallabitty ranging trom 0 to 500 gallans, with an expected value of 300 gallons. The correspanding cdr is given by

$$
1=e^{-\left(\frac{f_{u}}{331}\right)^{3.70}}
$$

The fuel ig diatributed uniformly : ith equal probabilsty over 40 to $200 \mathrm{ft}^{2}$.

9. A truck/truck collision has a 2-percent chance that are or more of the trucks is a tanker carrying flammable goods. This number is baged hpon relative mileage tata of ranker trucke and conventional trucks.

10. A truck/tanker collision has avallable fuel which ean vary from 0 to 10000 gallons. with an expected valuc of 5000 gallons. The fuel cdf is given by

$$
1=e^{-\left(\frac{f}{571 \overline{8}}\right)^{2.73}}
$$

The fuel is distributed uniformly with equal probabllity over $50 \mathrm{w} 500 \mathrm{ft}^{2}$.

11. Aoucollision fires originate as follows: 24 percent in the fuel gyatem; 36 percent in the area of tires. brakes, and wheel bearings. 21 percent in the electrical gystem; 12 percent in the cab; and 17 percent in other areas or from unknown cauges. This informallan 1d conoigtent with fire-accident data ${ }^{11-12}$ after deleting cargo arigin fires.

12. Noncollision fires that start in the fuel sygtem bave a 20-percent probability of involving the fuel tank; otherwise, the fire duration is uniformly digtrib:ted from 0 to 10 minutes.

33. Noncaltision fires that start in the arca near the tires, brakes, and wheel bearings bave a 10-percent probabillty of involving fuel; otherwise. the fire duration is uniformly diatributed from 0 to 15 minutes.

14. Noncollision tires originating in the electrical system have a 10 -percent chance of involving the fuel tank; otherwise, the fire duration is uniformly detributed from 0 to 10 minutes.

15. Nancolllaton fires starting In the cab have a 10-percent probability or fuel tank involvement; otherwise, the fire is uniformly distributed from 0 to $\mathbf{2 0}$ miruteg. 
16. Qher (unkawow source) noncolliaion fires have a 10-percent probabilty of fuel cank involvement; otherwiac, the fire duration io unformly dis* Iributes trom 0 to 15 minutes.

17. The Hquid hydrocarbon fucle from fuel tank or cargo have a burn ratl of $0.65 \mathrm{w} / \mathrm{lc}^{2}$ mil. which cartegpords, in peneral, to a gurface recessiton burn rate of $0.16 \mathrm{ln} / \mathrm{min}$. 29

18. For fuel purposes, wood or other cellulogic material is congldercd to be representative of nonlfquid combugtible cargo with a repregentative burn rate of $0.16 \mathrm{~b} / \mathrm{ft}^{2}$ min for the first 30 minutes linear decrease $;$ irom 0.24 to $0.08 \mathrm{lb} / \mathrm{ft}^{2}$ min) and $0.00 \mathrm{tb} / \mathrm{ft}^{2}$ min therearter. 28.39

19. Combusuble aurface area of nmiliquid combustible cargo is uniformly listributed from 100 10 $1000 \mathrm{ft}^{2}$.

20. The char cenofly (matertal remaluing after burning) is 35 percent of the original dengity of the nonliquid combustible cargo. 20,21

21. According to values coulirmed by acodent reports and complations, ${ }^{12}$ no fire-righting capabjlity is avalioble for 30 percent of the nre accidento, a local fire department may be summoned for 30 percent, and haid extinguisherg are utuzed in 10 percent. In the remaining 30 percent, "other" fireflghting efflorts are either mintmal or unknown. The relative merit of the last categary is based on a comparieon of properiy damage eatima:es and those from fre department of hand-extinguiahor firefighting efforts.

22. Hand exthgulghers are ineffective againgt fires if more than 75 gallons of fuel or 1000 pounds of solld combuat lole carfo become trvolved. Otherwise, find extingulshera, if avallable (10 percent), control the fre duraison, which is then usiformly digtributed between 0 and 10 mbnutes.

23. Local Ure departments, If avallate (30 percenkl, are effective against all inces. Unless a IIre burns out before they arrive, they control the duration. which is unfformly dist abuted from 15 to 45 minutes.

24. Otter (uakvom or unreported firelighting efforta, if avallable 130 perm cent), are ineffective agajnat fires if more than $\mathbf{2 0 0}$ gallons of fuel or 2500 pounds of other combuatble cargo becomea invalved. Otherwise, thits frefighting effort controls the duration, which is uniformily digtributed from 5 to 30 mlnuter.

It ghould be mentioned that many of the foregoing ageumptions and/or probability dist rjbutican went through geveral iterat ons. This was necessary to abtain overall regults that were corriatent wth such qualitative avallable data as frequercy of fuel tank involvement, frequency of combuatible 
corgo anvolvement. frequency of complete burnout, and fire durations proport fonal to property damage estimates.

Severnl sertes congisting of 10000 fire aceidento were gimulated on the computer. The repeatability of the results was excellent and indicated that 10 o00 simulation. constituted a statiaileal sample suflictenty in

The sens,tivity of the results to certain of the key (s nd mnse uncertain) assumptions was also examined. Following a truck (truck collision, the probabllity that the other truck tnontanker) Involved in the colluston carried Mammable goods was varied from to to 100 percent, with a nominal value of 30 percent. Also, the probabllity of the nammable cargo betrg imvolved in the lire was varied \pm 50 percent from a nominal value or 0.2. Firthermore, the probability of fuel tank invalvement in all noneollision fires was - ried by \pm 50 percent froen the assumptiong listed previousiy.

The results of the Mante Carlo prediction Bcheme ace shown in Figure $U$-3 as a cumulazive disiribution function. The gensitivity of the results to the variations mentioned in the previous paragraph was remarkably low. At the end of 5 minutes the distribution varied $=3$ pereent: beyond 20 minuteg the varlation was less than \pm 1 percent, even when wll the sensitivity parameters acted together to shorten or lengthen the predicted fire duration.

\section{Conclusions}

The predicted probability per truck mile of excoeding a specified fire onvironment is shown in Figure II -4 . Thege reauls are based on a truck accident rate ${ }^{2-5}$ of 2.5 per mulon mites, a fire lrequency per accident of 1.6 pereent, and the predicted durations shoum in Figure II-3. The temperature selected a repregentative for the truck fire environment is $1850^{\circ} \mathrm{F}$. 


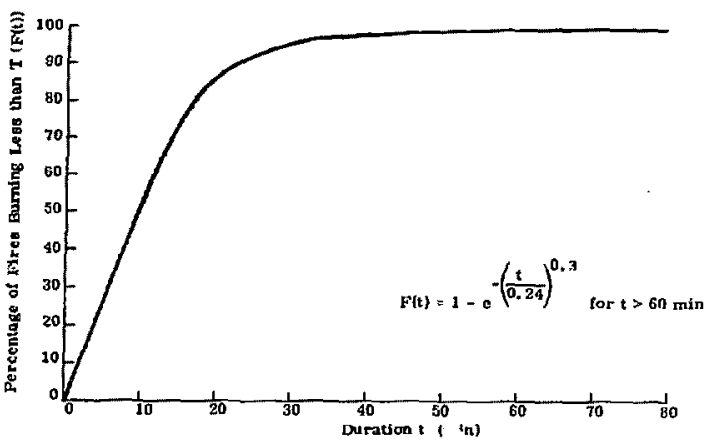

Flgure I-3. Cumulative distribution of thre-accident duration tor truck tranaport of large packages.

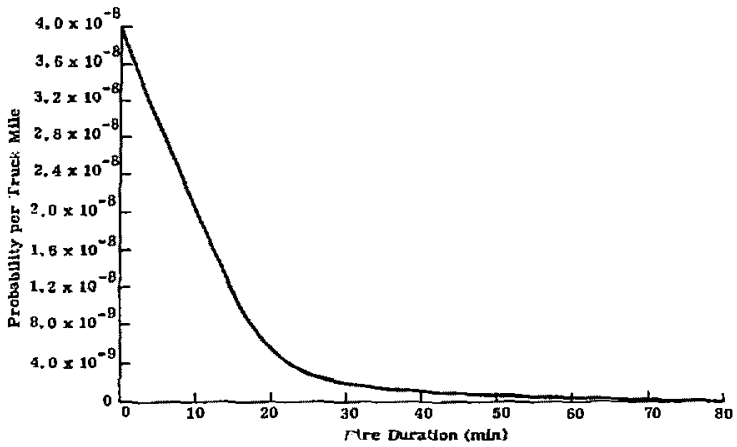

Figure 14-4. Probablity per truck mile of fire exceeding a givan duration. 


\section{Chapter 3}

\section{IMPACT ENVIRONMENT}

\section{Introduction}

The impact environment is agsumed to be present in each truck-colliblon accident. The impact envionment aseaciated with a single vehicle runing-olt-the-rcad accident or overturnlingon-the mrad accldent has alao been considered. This emvironmont is discugbed in detail in appendix $A$. The effects of a truck accident on a iarge package are difticult to quarify. For example, in 10\%-veloclty collation secidents the truck atructure will act to mitgate the environment and to maintaln the cargo regponse to levels below thone normally associated with "rough handling" enviranmentg. In hgh-velacity colligions, the miligation provided by the truck giructure may be regligible.

The existing accident data allow the computation of the maximum velocity change attributabie to the most severe single impact in a collision accident with a minimum number of asgumptlons. Hence, thls quantity, veloclfy change, was chosen a the parameter that best describes the impact enviranment. The the htatory agsockated with this velocity change is dependent upon both the trangport gystem characteristice and the closacteristco of the secal vehicle or object in the accident. If it is deairable to be highly conservative (to predict greater package damage than that reallatically expected) an object both masgive and rigid may be assumed to be representative of the aecond vehicle or object in the collifion.

\section{Collision and Noncollision Accidents}

Truck accidents have been divded thto two major categorieg, which paraltel the BMCS reporting system. 2-1 Appendix A of this report conlating a delabled discussinn of accident

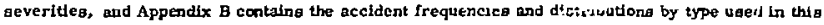
gtudy. The distribution of acddent types as stated in Table B-Vi is used. The prisuery abnormal cargo environment if due to overturning and running off the raed in 19 . B percent of the expected accidents. Collision with other vehicles, trains, or stationsry objects produces an impact environment in the remainiog 80,2 percent of the expected acdisting,

The overtum and runging-off-the-road accident was found to provide a very severe environment for the track drtver. Appendix A. The severe enviromment and frequent occur rence of ihis type of accident requirea its consideration. It is believed, however, that no eevere eingle im pacts are included in this type of accident; rather, it is a gradual slowing of the vehicle by a 
series of low-level impacts and ground friction. The oped at which the truck overums or icaveg the road can be egtumsted by the vehicle speed dlstributian developed in Appendix $C$ and ghown in Figure $\mathrm{C}-2$,

The impact anglyels that fallows ig linited to colliajon accidenta where the iningport vehicle is invalued in an accident with a econd vehlcle. frain, or stationary object.

\section{Analysis of Truck-Collision Accidents}

The anajytical approach employed ts to atudy each component of the collision accident aituation in itg mogt clenrly definable conliguration and to determine the parameters that characterize this gltuation. Each parameter lo expressed by a function that repreacents its frequency of ocurrence. A Monte Carlo analysis tecmique is then employed for random aampling of cach parameter dletribution. to determine the parameters of a angle accident, and to determine the impact parameters. Thls procedure le repeated until a sufticient number of trials have been made to allow aleulation of the distribution of the accident impact characteristice.

The analyaip of the eollieion aceident aitwation bs baged upon the following ageumptiong:

1. The vihrele colligions are ivelastc.

2. The initial and finpl velocity of the shipment truck; the direction of the veloctty ctange relative to the ahipiment truck's path; and a deacription of the second vehicle, train. or object involved in the colligion are guffictent to define the accident environment.

3. The ditutbution of bagte parameters developed in Appendiced $B$. C. and $D$ are aufficient for the purpose of this analyols.

4. The collibion enviromment is a random proccss and can be analyzed by the Monte Carlo technique.

\section{Environmental Description}

Computations of the veloctty change experienced by the truck and container an a regult of an Impact are baged upon the princtple of conservation of momentem. This frinciple can be atnted aD

$$
m_{1} v_{1}+m_{2} v_{2}=m_{1}+m_{2} w
$$


or

$$
v=\frac{1}{\left(m_{1}+m_{2}\right)}\left(m_{1} v_{1}+m_{2} v_{2}\right)
$$

where

$$
\begin{aligned}
& m_{1} \text { Is the mate of the ahipment truck, the puckige. } \\
& \text { and the tiedown syetem li.e., Uhe gross mass of } \\
& \text { the loaded shlpmen! vehlele). } \\
& \mathrm{m}_{2} \text { is the grass mass of the accond vehicle or the } \\
& \text { offective mass of a train or staitonary object. }
\end{aligned}
$$

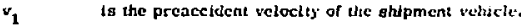

$$
\begin{aligned}
& v_{2} \text { Is the prearetdent velocity of the second vchicle } \\
& \text { or traln. ( } v_{2} \text { = } 0 \text { for sutionary objects.) } \\
& \text { * is the postaceldent velocity of the ghipment tehtcle } \\
& \text { and second vehtsle. }
\end{aligned}
$$

The velocity ehinge that the ghipment rehicle and package wll experience as a regult of a collision can be expresed as the difference between the postaccident and preaccident shipmen! vehucle veiocity.

$$
\delta v=v-v_{1}
$$

whore

$$
\begin{aligned}
& \text { is the impact velocity change experienecd by the shipment } \\
& \text { vehiele and the package. }
\end{aligned}
$$

The above equatlons were comblned to yteld the veloclty change $(\delta \mathrm{v})$ directly a furctio. of preaceident vehicle velocities and rehicle gross weighl. The velocity change equation can now be stated ag

$$
\partial v=\frac{w_{2}}{w_{1}+w_{2}}\left(v_{2}-v_{1}\right)
$$

where

$$
\begin{aligned}
& w_{1} \text { Is the gross over ne-road weight of the ehipment } \\
& \text { vethicle. } \\
& w_{2} \text { is the gross over-the-road weight of the gecond vehicle } \\
& \text { or the effective wefght of a train or gtationary object. }
\end{aligned}
$$




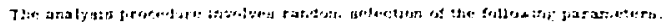

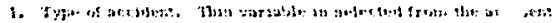

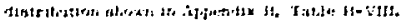

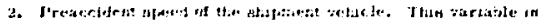

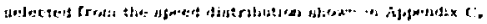
fisente: -4.

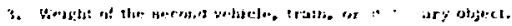

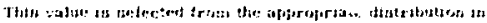
Apiecurtix 1).

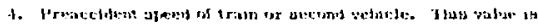

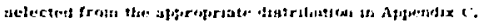

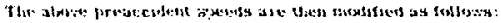

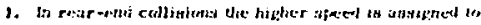
the strikifti abidi.:

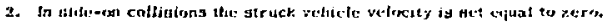

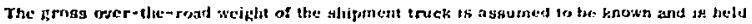
constant sor etach taet or calculatiung.

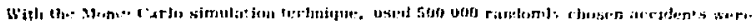

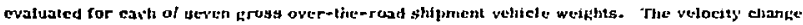

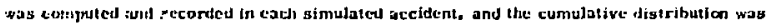
determinct. Tspicai mijentent vehicle wrights are:

1. 10 to 15 tans. This weight rejresents an ampty tractor-trafler truck. four to atx axles.

2. 15 to 30 inns. This weight range fs Included for eargo other than spent ronctor fucl.

3. 30 to to tons. Iings weight represents the typical grose weitht of epent reactor fucl highky ohipmeits ltractor, 't wler, pecage, spent fuel. and tiedenras asbietnl.

4. 50 to 50 tons. Ths weight repreants the normal overload permit range and uppir legal weight Iimits for intergtale bighway 1rameportation. 


\section{Collision Accident Impact Configurations}

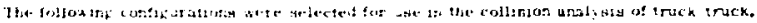

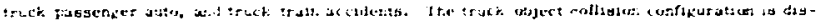

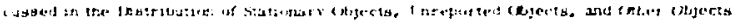

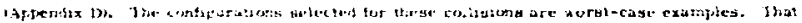

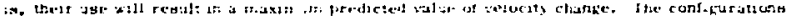

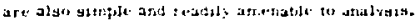

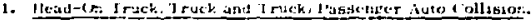

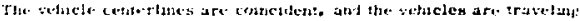

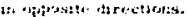

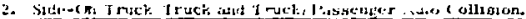

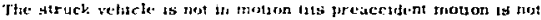

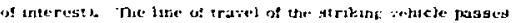

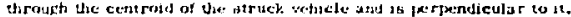

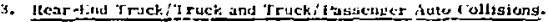
ldentical to leat-on exceft that the velifeles are traseling in the same Jirection.

4. Truck Into Traln Collisions. Ifertical to side-on truck/truck collisiong. with the truek ag the striking veluele.

5. I rain Inte Truck Collisions. Identical to side-as truck/truck tollsions, with the tran ag the strikige vehicle.

\section{Results}

The results of this atudy are presented both in graphlcal and in tobular form. The graphical piesentation allows a quick visual comparlson of the data for all weight categorlea, whereas the tabular form may prove useful in future siudies. In Figure 11-5 the computed velocity change is ploted as a function of ilg cumulalive Irequency of occursenec. The thape of this curve fs gimslar to thoge derlved in SLA-74-0001. To facilitate the evaluation of the results at moderate and high velocities, the cumulative distribjtion of the velocity change that fa grenter than or equal to a given veloctty change bis been plotted on a gemilogariuhnle scale. This information is f:esented in Fygure If-6.

Table II-IV contains the basic intormation plotted in Figures $\mathrm{y}-5$ and $I-6$. The values in Figure II-6 are computed as I minug the value llated in Table I-IV. 


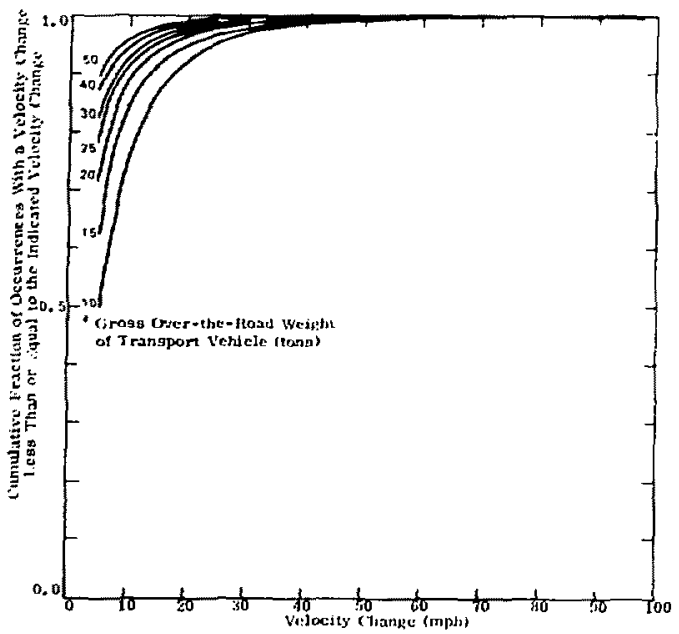

Figure 1t-5. Impact velocity change as a function of cumulati w trerjuency of accurrence for hishway transportation.

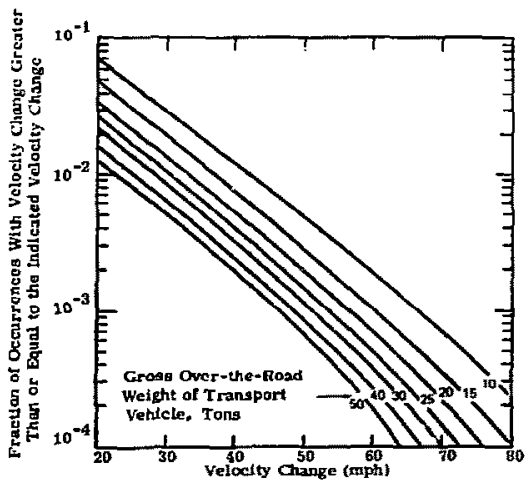

Figure D-G. Veloctly change due to impaet in a highway trangportation collisian acadert. 


\begin{tabular}{|c|c|c|c|c|c|c|c|}
\hline \multirow{2}{*}{ 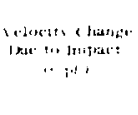 } & \multicolumn{7}{|c|}{ 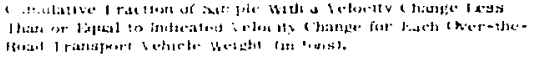 } \\
\hline & $1 \mathrm{~J}$ & 1:, & $21)$ & $n:$ & (1) & 10 & \&41 \\
\hline$x_{1}$ & 0. sindis & 0. 15220 & 0.71 .46 & $11 .=1$. & $11 . .21$. & 10.711 & 0.:Brity \\
\hline 10 & 1). : .11 & 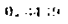 & I. & 0. '10-i & 0. & 10. $\cdot 4 \mathrm{~S}, 4$ & 0. ידים \\
\hline 14 & $17,+5,5$. & 11.1271 & $10 . \cdots 1.1$ & $11, \cdots, \geq 0$ & $0 . \cdots(b) \|$ & 11.121 & $0 . \therefore 5: 2$ \\
\hline 20 & 0. & $0 . \cdot+\cos$ & (1. $+4,4=$ & 11. $17 \geq 1$ & $11.9+75$ & 11. $14+3+3+4$ & 11. $5+472$ \\
\hline$\therefore$ & no. rot: & 0. & (3. $+7: 2$ & [1. $4,2,211$ & 0. "Nit', & 0. ' ', ים & 19. $\quad x+2=1$ \\
\hline in & (b. '701 & $0 . \cdot 310$ & st. ${ }^{\prime}, \beta_{1} r_{2}=$ & $0 . \cdot-31500$ & $0,14+11$ & $11.215+36$ & $0 . \cdots 1$. \\
\hline $1=$ & $0.1 .40 \mathrm{r}$ & 0.40187 & $0 ., 10$ & $0 .+4,51$ & $0.50+0.15$ & 11. "4: & (1. : suffitj \\
\hline 40 & $0.445 H$ & $0 . \leq 1$ & $0 . ! 4+4$ & $0, \cdot 4,450$ & 0. $!$ !nts: & U. $t^{t+4}+7 \%$ & 0. $: \pm e+7 \mathrm{H}$ \\
\hline ir & (1). 01022 & [), !!+', ] & 0. & 0. & דביצנ: 0 & 0. $4: 1,1\}$ & 0. 7 (1) \\
\hline in & $0.4 t+1,1$ & $0 . \operatorname{1070}$ & 0. $\{1,73\}$ & $0.95 m \%$ & 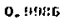 & 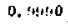 & 0. $5+4+1$ \\
\hline $5 \%$ & $0.4 \leq 170$ & 0. & 0.414187 & 0. 0 & 0. $9: 14106$ & O. & O. st!:ta \\
\hline 60 & $0.04+41$ & 0. (4), & 0.49542 & 0. sogn & D. $904 ! \mathrm{s}$ & 0. sons & Q. \\
\hline 65 & 0. Itstag & 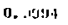 & 0, :4:!!G & 0.:4:157 & 0. บ5เบ! & 0, sty & \\
\hline 70 & 0. tgets & 0. toster & $0,4 ! y^{n}$ & 0. 5yital & & & \\
\hline $7 \pi$ & 0.4996 & 0. aysth & 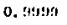 & & & & \\
\hline iso & 0.9097 & 0.50100 & & & & & \\
\hline ist & 0.3504 & & & & . & & \\
\hline so & 0.4555 & & & & & & \\
\hline
\end{tabular}

\section{Computation of Rates Associated With a Given Velocity Change}

Using the above information, ise rate of accident vecurrence associated with a given velocity change can be computed. Computc, for example, the expected accident rate with a velocity change less than or equal to $30 \mathrm{mil}$ eg per hour for the following highway transportation system.

Item

$\frac{\text { Item }}{\text { Spant Reactor Fuel Cask }}$

Tiedown System

Trajler

Tractor

\section{Weight (lb)}

55000

2500

12000

15000 
Jata for the 40 -tan, over-Uhe-road weight group wall be used.

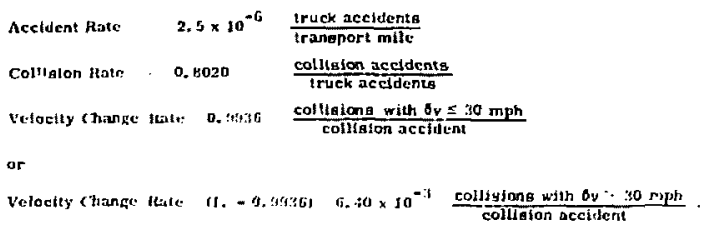

The expeced rate of accurrence, H. Is then

$11\left(2.5 \times 10^{-6}\right)(0.8020)\left(6.4 \times 10^{-.3}\right)$

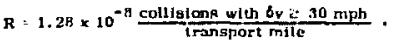

"The above ratiu may be inverted to obtadn the expected mileage per irangportation accident Involving thte velocity change.

\section{Conclusions}

T:e large-package motor-carrier impact envitonment has been evaluated and the protrabliliy of a given velocity range for a bystom has been determincd. The large packageg Iminjmum weight. 2 tong) are normally ebipped on open vehicles. A typical example of this type of package is thr: reactor spent-fuel cash. For this type of package the probability of a collision accidunt that re. sults in a volocity change of $30 \mathrm{mbea}$ per hour duc to impact fs approxlmately $10^{-8}$ per transport mile, or once every 100000000 package-transportation miles. The trangport vehicle structure, the package te-down syatem, and the torget tmpacted will all effect the acverity of the impact environent to which the package will be aubjected. Extenglve data aummarjea are include.I in the appendix of this repori to ald the serjous investigator in determbing those impact environmenta which may be of concem and to obtaln a raesonable eatlmate of their probability of occurrence. 


\section{Chapter 4 \\ CRUSH ENVIRONMENT}

\section{Introduction}

The truek crugh environment is difficult both to define aitd to quantify. Tlic tessgnation

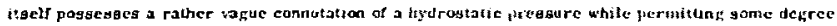
of dynamic. nonsymmetric losd applicasjon. We have. for thit tutudy, rather arbitrarily defined

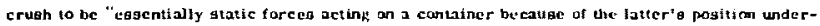

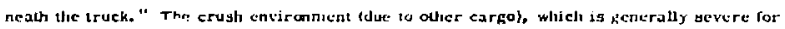
small packages, is insighticant for packabes that are carried singly or in gnall numbers. The. caviranment resulting from the trailer rolling over on the pactege is conajdered to be impact. and therefore jo not alayzed here; the only last considered ta that reauting from the trabler coming to rest an the packaje.

Thit chopter preserits the procedures required for calculating crush loads in motor-earrict uccidents and diccusges the variations that can be expected when differing load contigurations are considercd.

\section{Analysis}

The reduls sought in this analyais is the calculation of the probability of a containcr encountering accidentwelated crushing forces during transport and the estimate of the severity of these forces. The probability that the packige ends up underneath the trailer (p) was calculated by use of the collocation mulels developed fur aircraft accident analysis of Heference 1 . Volume n. An $8-\times 40-$ foot $\left(320 \mathrm{ft}^{2}\right)$ trailer bed $\mathrm{w} 2 \mathrm{a}$ asumed as the erughing area. Dimengions withln which the container and overturned traller vere assumed to lie varted in width between 40 and 50 feet and in length between 75 and 100 feet. with these vartationg both in timengins and in models. $p_{c}$ was calculated to be in the rarufe of $2 \times 10^{-2}$ to $0,5 \times 10^{-2}$. A value of $5 \times 10^{-2}$ was selected as being repregentative.

$$
P_{c} \text { (probability of cruah, given a colligion or overtura) }=5 \times 10^{-2} \text {. }
$$

This value is very cumservative. In aceidents where the large package breaks loose, the collocation model agsumes that the final position of the trailer and package arc independent: hovever, they are not. If the package does not geparate from the traller, the foregoing probability of crugh arates that 1 of 20 accidents will result in the trailer scsting on the package. Available acddent data indicate a lower rate. 
The probablity distribution of crush load. glven that a crush occura, was modeled with the assumptlons that (a) the trailer is overturned and (b) the contalner lles betwetn ine traiter bed and the ground. Beam analysis wsg uged, and two beam-loading configurations we re investigated.

These configurations are shown in Figure $\mathbf{I}-7$. For loading configuration 1 (trailer bed aupported by container and ground, the force on the container (F) is given by

$$
F=\frac{w b L^{2}}{2 t}
$$

where

$$
\begin{aligned}
& \text { F is the cruahling force (lb/ta) } \\
& w \text { is the unit average } t \text { ralles weight }\left(\mathrm{dh} / \mathrm{ft}^{2}\right. \text { ) } \\
& \text { L is the total trabler length (ft) } \\
& l \text { Is the distance from the point of support to the } \\
& \text { package (ft) } \\
& \text { b is the nominal width of the trai, gt (ft). }
\end{aligned}
$$

Since the entie traijer weight (W, Ib) ls equal to ubl. Kq. (II, 14) mav be rewitien as

$$
F=\mathbf{W} \frac{\mathrm{L}}{2 \mathrm{I}}
$$

For loading configuration 2 ftrailer bed gupported by container and rigid con.uection to tratler c..assis $\}$, the container force ts given by

$$
F=\frac{w b}{\theta I}\left[6 L^{2}-4 L I+l^{2}\right]
$$

The foregoing descripuon is paraluel to that in Reference 1, Volume IL. The major dirferences in the large-package environment are

1. The abgence of oher cargo on the trabtyr.

2. The absence of dynamit crush environment caused by other cargo.

3. The crush laad capactity typlcally found in acckdent-reslatant contatnere.

The erugh environment can be adequately gpecined by a gingle lo: $d$ value. It can be noted 15 oro the above equations that the maximum value of $F$ is

$$
F_{\max }=w h=W .
$$



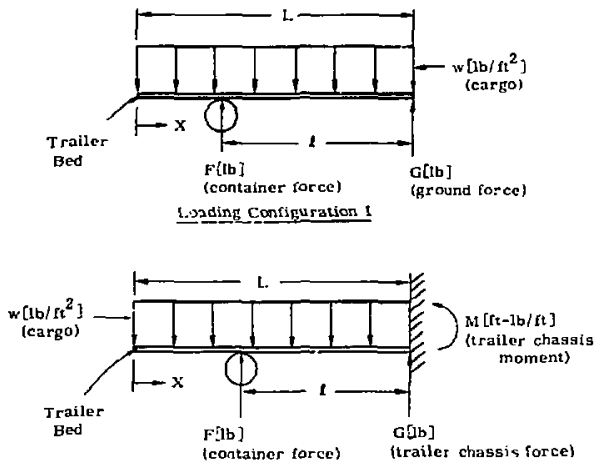

Loading Configuration 2

Figure Il-7. Beam-amalysis landing contiguradons.

Thle value may be used as the expected maximum static crubh loading. The typlcal shipment of large packages (e.g. - opent reactor fuel casks) is by means or large flat-bed trailers with rigid tiedown systems. The larger trailer an.J tiedown system woight is normally leas than 15000 pounds, and the trallers are nominally 8 feet wide. Besed on these figures, the maximum static crush loading, F, is 15000 pounds and the distributed crush loading can be estimated as F/b, or I875 pounds per lineal coot of landed area.

For convenience, this value is rounded to 2000 pounds per limeal foot.

\section{Conclusions}

The statlc crugh environment can be described by its estimated frequency of occurrence and by the maximum expected cruah value:

P(probabilty of crush, given a collision or overtum) $=5 . \times 10^{-2}$.

Maxdmum expected crush force $\leq 2000$ pounds per lineal foot over an 8-foot length. 


\title{
PART II
}

\section{Chapter 5 \\ IMMERSION ENVIRONMENT}

\begin{abstract}
Introduction
As compared with many of the other anvironments, no actunl data are available from which it is nossible to infer the probability of cargo being immerged. It is, however. pos givle to use gome Indlrect data which. when coupled wh models or river beds and ditebes, can lead to an sstinate of the relative significence of the immersion cnvironment in terms of its produatifty of accurrence and depth of immersion. With regard to duration of ummersion, no indirect datu such as that utilized for fire duraiton estirations presentiy appurars to exist. ${ }^{55,56}$
\end{abstract}

\section{Analysis}

Three separate tzpes of evente are considered: \{1\} accidents that occur during bridge crossings, \{2\} rondaide ditch immcrsions stsulting from rollovers or eargo ejected from a traller. in eollisiong, and $\{3$ ) accidents in which the motor carrier keaves the road ayl enters adjacen: water.

\section{a. Hriclge-Crossing Accidents}

This amalysis is based on the assumption that the occurrence probabijity of accidents on bridges is equal to motormenrrier aceident rateg in general. Nuhough argumente either to increase or to decrease this rate can be made, any other assumption is no Icss difficult to justify quantitatively. With the equlvalence aabumption, the probability of a bridge accident is simply the ratio of bridge miles in the continental L. S. to total road mlles times the highway accidert sateg.

Reference 22 lists the notable highway bridges in the U. S., a total of aboul 37.9 bridge miles, Although this mileagc includes some bridges under which the frater flow is mirimal over the entife year. it does not include the large number of shorter bridges in which a real immersion thrent can exist. Father arbitrartly, therefore, a total of 100 miles of bridge length was chosen to represent the threat. :

\#a shown lnter, the probabuity of an immeraion threat to large packagea is relatively amal in compartion to the probabllities of tire, impact cr wh, and puncture. 
Simliar problems exigt in dotining the highway mileage corresponding to this length of bridge. Conservatively, as most of the bridgee are on tederal highwaye, the value of 150 o00 miles of raade under federal control ${ }^{23}$ wag uged. This leads to a probability of $7 \times 10^{-4}$ that, if an accident occura. it takes place on a bridge. This figure could eastly be in error by at least a factor of 5.

As most accidents are of a relatively minor nature and most decp-water bridges are rather heavily protected, the occurrence of an accidznt on a bridge fe not tantamount to an immersion incident. As an order of magnitude calimate, it is asgumed that 1 percent of the containers inyolved in an accident on a bridge will be immeraed. This aseumption is based boin an the probabuty of the entre tralles dropplng itso the water and on the probubility of a delachcd package falling off the bridge.

The aceident sate for trucks was assumed to be $2.5 \times 10^{-6}$ per mile. Combining this will the probabtuty of the accident occurring on the hridge art. if this happens, the probubility of the package becoming immersed leadg to an estimatc of about $1.8 \times 10^{-11}$ immersicns per mile.

With this figure used ag the immergion rate for bridges, the depthe were catimated by assuming a mean water depth of 10 fect and by rssuming that only fi percent of the deptho equa] or exceed a dredged channel value 24 of 40 reet. Therelore, the probability per packagc mile of being immersed is $2.0 \times 10^{-11}$; of being immeraed in greater th. $J$ leet of water is $9 \times 10^{-12}$; and of belng immerted to depths greater than 40 teet is $9 \times 10^{-13}$. These daea are graphically depicted in Figure $31-9$.

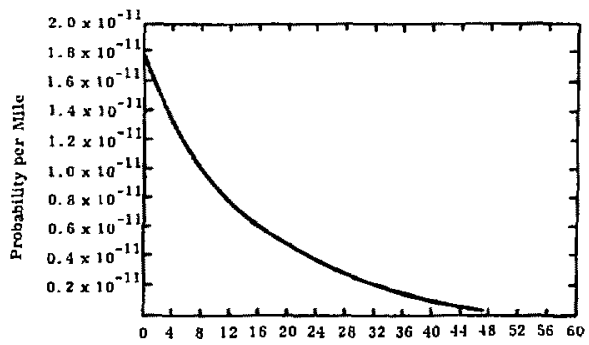

Depth (ft)

Figure Il-8. Probabllity of package betng immersed in a depth greater than depth giten for bridge accidents. 
The oycrtum rate for motor carriers is labulated by the Burean of Motor Corrier Safety (gee Chapter 1 and, for example, Referenec 4). This rate, averaged over 3 years, is about 2.9 $9 \times 10^{-8}$ per mile. Agaln, an asgumption of the probability of immergicen for a given package, given an overturn, te required and gath an arbitrary order of magnitude value of 0.01 has bech choseth. The probabulty of immersion due to $r$ all-over is, therefore, about $1.9 \times 10^{-10}$ per 11 ile.

The depth of the water in ditches muat be estimated, Certalnly, the probability of a diteh contalning appreciable water is no greater than the 0,01 value when averaged over ihe entire U.S, : in some aress, it probably is lesg than $10^{-4}$. Use of the 0.01 value leads fo a maximum immer gion probability, per mile, resulting from roll-over of $1.9 \times 10^{-10}$ per mile. When water is present, the assumption that it has an average depth of 0.5 feet and a 5 -percent probability of a depth greater than 3 reet leats to the dato shown in Figurc II-g.

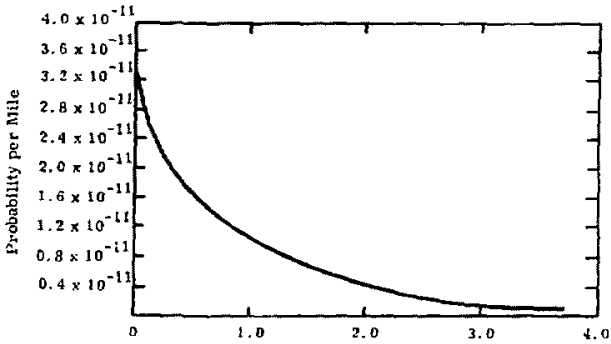

wepth (fe)

Figure 11-9. Probability of package being immerged in a drpth greater than depth given for ditch accidentc. 


\section{c. Runorfs}

From Appendlx B (Tables B-l' \& B-I'Il, about 17 porcent of the major highway accidents in" tolve departure of the truck tram the driving surface. Certainly, ne more than 0 , 1 pe resent of these accidents will result in the out-of-control vehicle triving into adjacent streanis or lakes. Thls results in an fmmersion probabilfy for rumofts of atmut $+\times 10^{-10}$ per mile. The vehicle is asisumed to overiurn in the tvater when maxinum depth is reachett, and the denth is asaumed bo vary lineariy up to s maximum of 5 fect. These results are shown in Figure II-10.

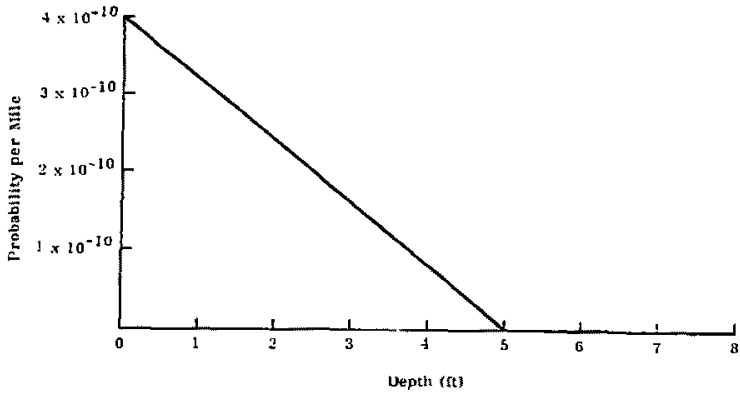

Figure It-10. Probability of package being ismmised in a deplh greater than depth glven cor runoff accidents.

Summation

From these data the pro'sability of immersion, given an overturn or collision, is simply the sum of $a, b$, ard $c$ ditcted by the rate of overturn and collisfoas, or

$$
\left.\left(1.8 \times 10^{-11}+1.9 \times 10^{-10}+4 \times 10^{-10}\right)\left[\left[2.5 \times 10^{-6}\right)<0.9\right\}\right]=: 2.7 \times 10^{-4} .
$$

Most of these are relativaly minor, however, as can be seen from Figure II-11, which is the environmental degcription fur immergion achicyed by adding the results of $F$ 'gures II-8, II-9, and 1I-10, Figure 11-11 ahows that only about 0,001 of the fmmergion accidente or $3.4 \times 10^{-7}$ overturn or collfaion accidente result is a depth greater than that specitied in Reference 25 . The tolal Immergion rate, per mule, 18 ghown in Figure $\Pi-12$. 


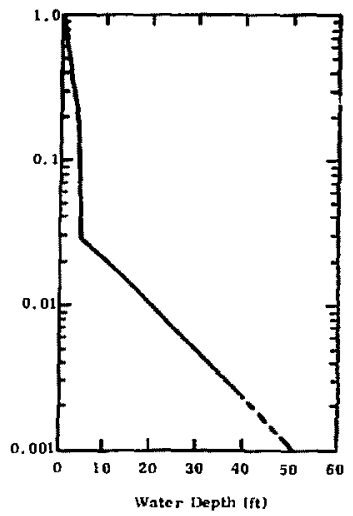

Figurc II-1 1. Probability of Immeraion at a depth grealer than that shown, given immersion.

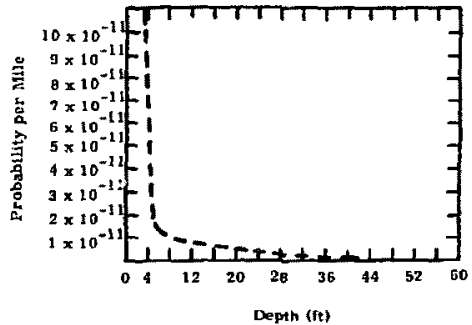

Figure 1-12. Probabillty, par mile, of inmersion in a depth ereater than depth given in a motorcarrier accident 


\section{Conclusions}

The immeralon environment is expecte 1 to occur very infrequently. It has been estimated that (1) only 1 accldent in 3000 will involve immersion of the package and (2) the probsbllity of immergion to depths greater than 4 feet is of the order of $10^{-10}$ per packoge 1 ransport mile. 
PART II

\title{
Chapter 6 \\ Puncture Environment
}

\begin{abstract}
Introduction
"(Of ull the potential threats to radjaactive ar hazardoug moterial cargo, nose is more difficult to dit:tabe, more uncertain, snd more random in noture than the potential pancture of a cratuizer ly portions of the deformed erailer, by other eargo, or by external sources. Decauge of the emmplexity of this thecat, it is srobably safe to ftate that it is net posslble, regardicss of the amesunt of expended effirt, to define accurately the muncture enviroment." This atatement wos used to Jescribe the puncture environtment in Referenec 1, volume 111 . The data base for puncturc of packnges in highway accidents has not been expinded.
\end{abstract}

An analysis of the puncture threat in brge-package ratload accivents hay been achleved by use of raiboad tank car pinsture tata. This analysis la diseunsed in Chaper 6 of Part bl of this report. The pascture thrcat la the rail enviroament is considered to be greater than that in the highway eaviroamer: (given a pancture wituation) because of the presence $n$ I the raitcar eoupler as a potential probe in each such situation. The resposse of truck transported packeges to punc-

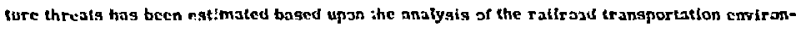

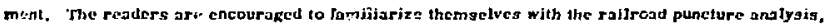
Chaper of ar Part If:, wefore applying any of the motor carrice findinge to a spacific problem.

\section{Puncture Threat}

This analyals will utilize the sume method that was developed in the rali eransport puncture lnvestigation. The methot is applicable to determining the order-of-magnitude of the puncture threal. A scarch uf truek accident records did nxe establesh any potentlal puncture probeg ouch 25 the rail-car coupler witich would serve as a basis for the analyals. Therefore, it was necesanry to jgsime a probe and an asgosfaled probe failure model. The probe chosep wad one which

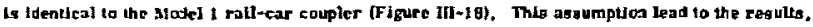
whlch are shown in Toble IJ-XIf. The effective impact relocities for plancture were entimated to be the same as the single vehicle preaccident velocitles. These velocltieg obtained from equation C.1 and are shown in Figtre C-2. It was further assumed that no gituaticat leading to parteage punclure would occur in collision acetdents involving paggenger autas, light statimary cijects, or terrain features. Theoe teems are detined in Appendix D, pages D-4 and D-7. These three clagses of colligioas accosint for 73\% of nil truck accidents involving colligions. 
The probability of a pujeture satuation given a truck accident has been taleulated as the product of three events: (1) hav pruse doeg no: foil, (2) the impact velocity is sufficient to penetrate given a nonfailing probe, and 13 ) the colliston does not involve pasfenger autos, light stationary objects, or terrain features. This probability is tabuloted in Tabte $\|-V$ for sulected package wall thicknssess.

TA13LE 11-:

Probabtlity of Uceurrence of a Puncture Sttuation Civen a Truek Transport Colligion Acetdent

Packge Wad Jhlekness

(nild stcel)
$0.4375 \quad(7 / 16)$
0.50
0.75
1.05
1.25
1.50
1.75
2.00
2.50
3.00

Yrobability of puncture Situgition

$2.21 \times 10^{-1}$

$2.18 \times 10^{-1}$

$2.01 \times 10^{-1}$

$1.04 \times 10^{-1}$

$0.38 \times 10^{-2}$

$2 . \mathrm{Ag} \times 10^{-2}$

$3.97 \times 90^{-3}$

$2.31 \times 10^{-3}$

$4.36 \times 10^{-B}$

$5.56 \times 10^{-12}$

\section{Probability of Puncture}

The probabllity of puncture given a puncture situation must be letermined, J1 can be seen froth the above, that a puncture gituation is deemed to ocuer in every colligion accitient where effective impact velocity is above the puncture threahold velucity and the collision doen not involve passenger sutas, Jight statfonary abjects, or terrain features. This prabability fpuncture given a puncture situation) wib be eatimated to be the game for truck accidents is for 1 dilroad accidents. The avaliable rallroad taik-car puncture data, discussed in Chapter III-6, indicates that no more than 1 out of 100 collision situstions in the rallrond enviroament resulted in tank-car puretures. it will be assumed for track accidents that the probability of puncture glven a puncture situation is $10^{-2}$.

\section{Conclusion}

The reaults of this analysig are pregented in Table II-V1. In addition to the above factor, the probabllity of a colligios accidert given a reportable truck accident hag been determined to be 0. Bo. Table B-6. The probabuity of a repartable truck accident given a mule of tror 1 has been eatlenated to be $2.5 \times 10^{-6}$. 
TALLE, II-VI

Probability That a Package will He Punctured

\begin{tabular}{|c|c|c|c|c|}
\hline $\begin{array}{l}\text { Package Wall } \\
\text { Thlekness } \\
\text { (a) hin. }\end{array}$ & $\begin{array}{l}\text { Probability por } \\
\text { Transpart mule }\end{array}$ & $\begin{array}{l}\text { Probsbility per } \\
\text { Reportable } \\
\text { Accident }\end{array}$ & $\begin{array}{l}\text { Probability } \\
\text { Truck Colli. } \\
\text { gon Accldent }\end{array}$ & $\begin{array}{l}\text { Probability per } \\
\text { Accident whero } \\
\text { Probe Fallure } \\
\text { Controls }\end{array}$ \\
\hline 0,4375 & $4.42 \times 10^{-3}$ & $1.77 \times 10^{-3}$ & $2.21 \times 10^{-3}$ & t, \\
\hline 0,50 & $4.36 \times 10^{-0}$ & $1,74 \times 10^{-3}$ & $2.18 \times 10^{-3}$ & 1. \\
\hline 0.75 & $4.08 \times 10^{-0}$ & $1.63 \times 10^{-3}$ & $2.04 \times 10^{-3}$ & 0.99 \\
\hline 1.00 & $3.28 \times 10^{-8}$ & $1.31 \times 10^{-3}$ & $1.64 \times 10^{-3}$ & 0.84 \\
\hline 1.25 & $1.88 \times 10^{-0}$ & $7.50 \times 10^{-4}$ & $0.38 \times 10^{-4}$ & 0.50 \\
\hline 1.50 & $5.76 \times 10^{-10}$ & $2.39 \times 10^{-4}$ & $2.80 \times 10^{-4}$ & 0.16 \\
\hline 1.75 & $7.34 \times 10^{-11}$ & $3.18 \times 10^{-5}$ & $3.07 \times 10^{-5}$ & 0.023 \\
\hline 2.0 & $4.62 \times 10^{-11}$ & $1.85 \times 10^{-5}$ & $2.31 \times 10^{-5}$ & 0.014 \\
\hline 2.5 & $-\cdots$ & $-\cdots-$ & $4.36 \times 10^{-10}$ & $2.9 \times 10^{-7}$ \\
\hline 3.0 & $\ldots$ & $\ldots$ & $\ldots$ & $4.0 \times 10^{-11}$ \\
\hline
\end{tabular}

(a) Mild Stecl Package Wall Assumed 
PART III

TRAIN EN: IRONMENTS

III-1, 2 
PART III

Chapter 1

\section{DEFINITIONS AND ACCIOENT RATES}

\section{Accident Definition}

The definition of "accident" as uged in this study is congletent with the definition of "train accident ${ }^{* t}$ ag ges up by the Unfted Stuteg Code of Federal hegulationg 26 in that it inctudeg acefdente associated with the operation or movement of erains, jocamotives, ur cars thal resull in railriad equipment, lrack, or roadbed damage in excess of $\$ 750$.

\section{Accident Rate}

The accident rate appropriate for this study is that for frcight trains only. The breakdoun of freight irain accidonLs an Clagg I an' Cass II line-haul railroads in $19722^{27}$ is given in Table III-I.

TABLE III-1

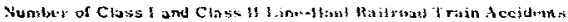
to Freipht Trains in 1 !riz

\begin{tabular}{|c|c|}
\hline $\begin{array}{l}\text { Accident } \\
\text { Clagification: }\end{array}$ & $\begin{array}{l}\text { Vumber of } \\
\text { Train Accidents }\end{array}$ \\
\hline Collisiong (one (reight) & 172 \\
\hline Collistons (twn freight) & 68 \\
\hline Derailments & 3880 \\
\hline Other & 465 \\
\hline
\end{tabular}

${ }^{a}$ For defitition of accident dastifications, aee Reference $2 B$.

brom Table 123 of theference $2 \%$. Also 1 sted in Reference 2 are about 2500 high way grade crosaing accidents which are clagebled as "train aerviec" accidenta. This mumber is composed of accidents that (1) are elther less than $\$ 750$ in Bcwerity ar (2) do not invalue pergonal injury or derailment or result in collision with another araln. Because of the 1ack of threut to cargo in these acdideos, they were not considered In determlning the accident rate. 
Doubling the number of two-freight colligions and adding the accond column pryes a to:al of 4653 freight tralng involved in accidenta in 1972. The total Clase I freight irain mileage ${ }^{29}$ in $1072 \mathrm{wag} 451 \times 10^{6}$. Since Class I rallroade repregisnt 99 percent of the railroad indugtry in terms of trafic. the traln accident rate, $R$, is

$$
F=10^{-5} \text { traln eccldent per mile. }
$$

For $\mathrm{R}$ gmal, as is the cuse here, the rate equale the probobility of a train accident in 1 mile of travel.

\section{Accident Environment Definitions}

Interactions between a rallear or pockage and its surroundigs during an sccident are labeled "eccident envircoments." The five accident environmente- fire, impact. crush. puncture, and immersion-as uged in this atudy ghould be interpretea according to the specific definitions given below.

Frc. Exposure to a high-temperature environment produced by combustion. Example: the interaction of a package with a fre following a derailment.

Impact. Striking or being struck by an objecl thot has no starp projections. Example: the ineraction of a rajteas with an adjacent railear in a colligion.

Crugh. Subjection to atructural loads that may either be highiy localized or be extended over a large area of the exposed package but that cannot be categorized as impact or puneture. Example: the forees on a package that rests between the freight car and ground after an accident.

Puncture. Striking or being struck by an object that penetrates the protective structures of the package. Example; the impalement of a package by the coupler of a freight car.

Jmmeraims. Submeraion in a lsquid medium. Example: the Eubmersim of a package in water afler a car derails on a bridge and falls into a river.

The envirotumente as epeclified in thi g report are icanaportation vehicle environmenta, not packsige environments, becaube the available abnormal environmental dat deal with tranaport vehicles rathe $r$ than with their cargos. The vehicles in thig cage are callroad Oatubed freight carg. Specific enplyals of particular package design and tiedown structires, if any, is neceseary for further reduction of data to the package response. The data in this report were developed to facliltate thege followron detailed analyoes. 
The most common :ail accident (Bu percent of all rail accidents) is derailment of a section of the cars in a train iaving no prior colligian. In this case the lead car of the derailment separates from the preceling car and leoves the tracks. At geparation from the precedtng car, the brake , syatem is activated over all cars in the train and both gections of the train are brought to a halt. Derallment thus involves a series of cars, each leaving the track at a succesifvely slower speed. Because of the increased resistance to movement after leaving the track, the lead cars are deceleraind at faster rateg than the following cara and a serics of low differentifal velocity impacts realis. Hecause high incrtial forees arc involved (owing to the weight of the loaded ears), it is not un.wual to encownter reports of one car overriding another as a result of a low difforential velocity impact.

The differentiol velocitjes of impacting cara in colligion accidents are typicaliy much higher than those of care in derailment accldento. However, theac large differential velocity changes experienced by cars near the impact point rapidly diminish to velocities that are within the normal impact capabilitieg of freight cars. This point is establighed by the fact that many of the cars in trains involved in a collsion whll remain on the rails with their structure intect. Extreme equlpment damage is usually Lmited to the locomotives and lead cars in head-on colliaions and to the locomotives, caboose, and adjacent cars in rear-end collisions. 


\title{
Chapter 2
}

\section{FIRE ENVIRONMENT}

\author{
Introduction
}

Fireg resulung from train accidents have a wide varlety of causes and a range of screrities that extends (rom incongequential (lege than $\$ 100$ property damage) to mulimillion-dollar holacauses. The data sources ${ }^{30-32}$ are helpful in prowding information related to type of accident (colligion, deraitment, ete), trequency of nre, cause of Are, and property damage esifmates. However, the aceident records do not prowde the information required to deseribe the enviranment levels expected in a fire accident, buch as (1re gize, intensity (temperature), localon, duration. and fued source. The lack of commonality of rallroad fires and the paucity of apecific data make the development of a reagonable probablistic degeription of the fre enviranent a gamewhat subjective exercige.

In conirast to as aireraft accident, ${ }^{33}$ where the postera th firc can be described almost exclusively in terms of the fuel situation, the traln fire has a largo numbor of variobjes that ean affect the resultant fire. Such variables are accident type fcollision, derailment. rail crossing, vandalism. etc), type and amount of cargo (tammable or nonfammablc\}, type of car (a) invalved (boxear, tanker car, etc), involvement of locomotive fuch, and availability of firefighting equipment and peraonnel. The Lage number of variables and the lack of spectific data led to the use of a Acmte Carlo technique for developing a deseription of the train-accident fir s environment. $\Lambda$ brief description of this prosedure can be found in Felerence 34. The Monte Carto approach utlizes the avadlable data, along with enginecring judgments and theoretical predictions, to determine the consequences of cartain evenis or whe senuesce of evonts.

The regulting fire tegcription has a degrce of uncertalnty becauge of lack of data. Qualftative comperisong of the fire severity and duration with the property damage diatributions can be made. however, to adjust the mare sensilive input parameters until reasmable agreement is obtained. 


\section{Data Base}

The primary data sources for determining the frequency and severity of train-accident fires were Reference 30 (for the ycars 1969, 1971, and 1972) and Reference 31 (also for 1972). Unfortunately, the two data sources for 1972 have a large discrepancy in the reported number of fires oxpertenced by rall transport. If was aggumed that Reference 31 cunained the correct Information, slnce compillng fire-accident data was the opecific purpose of that atudy'; in Reference 30 the fact that a fire occurred is conneclion with an accident may have gone usrecorded and bome "fire only" accidents may not have been reporied.

Hefercnce 31 is a compilation of fire accidents for 1972 of 13 U. S. railicads, representing 99 I13 track mlles, and two Canadian railroadg, repregenting 41304 track mileg. Slnce there are approximately 200000 traek mstes (excluding parallel (racks) in this country, 20 the experienec of the rallroads reported in feference 31 is taken to be repreaentative of the $U$. S. radroad induetry as a whole. In 1972 the 15 railroadg reported 2152 fires with property damage logses of $\$ 4754282$. Fire lossos of $\$ 1000$ or less were reported for 1378 of the accidents and of less than $\$ 10000$ for 1941 of the accidents.

Freight trains and/or their contents were involved in 897 of the fires. Approximately 1 percent of the collision and derailment accidents resulted in a fire, with an average properfy damsge of saz 000. Including only those accidents where property losses exceed $\$ 2000$, Table Ifl-1I ahow日 the relalive frequency of varioug types of freight train accidente, how often fire occurs in those accidenta, and the percentage of the total fires accounted for by each type of aceident. ats shown, fires dut to accidenta odier than collision and derailment account for mosi fireg. These aceidents have a wide range of severity and, although they are much more frequent, generally are much less destructive than fires follawing collision of derailment. The umusually high trequency of fires from "other" accidents is a result of the fata discrepancy between Relerences 30 and 31. It ig not belheved that fires actually occur in 90 percent of all "other" accidenta but rather, as mentioned previously, that this apparent rate stems from the differences in reporting in the two sources, Vging the National Fire Protection Agsociation (NFPAl data as representative would Indicate that in 1972 there were 420 accidents other than collision and derajlment where fire was involved and damage exceeded $\$ 1000$, whereas data for the same year from the Federal Railroad Adminiatration (FRA) 30 chow's a total of 46.7 "other" accidents where damage exceeded $\$ 750$. The frequency of Irre in these "Oher" accidents cannot be determined from the FRA data alone. However. gince 420 fires (excluding colligion and deratiment) were reported by NFPA, the resulting tire frequency from "other" accidente is 90 percent, as shown in the table. A more plauslble explanation, however, is that the two referenees are not reporting the game accidents. It is assumed that the NFPA data are correct; lience, the total number of fires is consistent and fire Irequency of "other" accidente will not affect the resulte. For all freight train fires from accidenta of various caugee (including thoge with lesg than \$1000 damage). Table III-HI ghowe che percentage of Eres, the percentagc of the property damage, and the average coat per accident. 
TABLE IT-L

Rottroad aceident Fre Rateg

(frelght traing, darnage $>\$ 1000$ )

\begin{tabular}{|c|c|c|c|}
\hline $\begin{array}{l}\text { Accident } \\
\text { Type }\end{array}$ & $\begin{array}{c}\text { Percent of } \\
\text { Total Accldente } \\
\end{array}$ & $\begin{array}{c}\text { Percent of } \\
\text { Flre Frequency }\end{array}$ & $\begin{array}{l}\text { Percent of } \\
\text { rolal Fires } \\
\end{array}$ \\
\hline Collision & B. 62 & 1 & 0.74 \\
\hline Derallment & 83. 39 & 1 & 6. 38 \\
\hline Other & 9.09 & $90^{3}$ & 89.88 \\
\hline
\end{tabular}

See discusaion in text canceraing data discrepancy.

TABLE In-11!

Causes and Costs of Frcight Train Fires (includes all fires with monetary damage)

\begin{tabular}{|c|c|c|c|}
\hline Cause of Fire & $\begin{array}{l}\text { Percent of } \\
\text { Fires }\end{array}$ & $\begin{array}{c}\text { Percent of } \\
\text { Cost }\end{array}$ & $\begin{array}{c}\text { Average } \\
\text { Cost/Accident }\end{array}$ \\
\hline Fleating Linits & 7.86 & 2.79 & $\$ 1.869$ \\
\hline Brake sioe Sparks & 26.91 & 17.84 & 3.491 \\
\hline Hot Boxes & 6.95 & 3.54 & 2,671 \\
\hline Power-Related Sources & 2.21 & $0.7 B$ & 1. 861 \\
\hline External Sources & 25.92 & 7.83 & 1,591 \\
\hline Conailment. Collision & 2.46 & 46.58 & 51.712 \\
\hline Spontane ous & 1.96 & 0.83 & 2,221 \\
\hline Enknown, Other & 25.93 & 19.81 & 4,024 \\
\hline
\end{tabular}

Data on the commodities carried by the railroads, typical Joadings, and amount of Mammable goods, as well as the train makeup laverage number of boxcars, taskers. Mat cars. etel were obtained from References 29 ana 35 . In addition, Reference 35 was used to determine the amount of potential flammable material available from the cas construction materials of certain cars (such as wooden floors) and typical fuel capacities of the locomotives.

In gummary, the data sources provde a reasonable base for determining the cause and trequency of railroad fires and aiso the availability of combustlble materials. Fowever, they do not provide information necessary for a description of the reguling thermal environment. It is necessary, therefore, to model the expected envirorment by uge of analytical techniques to predict the fire severity based on a probabllisic avalabllity of combusuble matertala from vartous types of accidents. 


\section{Fire Description}

Since the accident data do not contain the quantitative information neceasary to dcecribe the fraln-accident fire enviconment, other theoretical and expirimental information was uthied. It is apparent bath from theory and from experimente that exact predictions of temperatures in any particular fire cannot be made. Expected temperatures are a function of the fuel, oxygen supply, ceometric configuration, and other variables. most of which can only be estimated in an accider: gituation. Howover, most lifuid hydrocarbon fuels yield approximately the samp measured name temperatures for open burning and, in general, fall in the range from $1400^{\circ}$ to $2400^{\circ} \mathrm{F}$. 13-15 Furthermore, the Dane temperatures of most of the other cxpected combugubles all in that same range, gencrally toward the lower end. 16,17 The probabillty distribution of the train-fire tersporature was assumed, thereforc, to be represented by the distribution determined prevlously for aireraft fires ideseribed in Volume 1 of Refecence 1$)^{33}$

From previous analyseg. ${ }^{33}$ the fire can be conaidered to be essentially a blackbody radiation source for a flane thickness of 4 feet or more and the convectue houting can be neglected.

\section{Fire Duration}

From accident fo accident, the wide variety or types and of amour's of combuatibic material available to provide fuel for the fire precluded a closed-form andlytic rescriptian of the probable burn time. and the lack of detailed data prevented a statistical represi ntation of the duration. A Monte Carlo prediction gcherne uas used, therefore, to obtain the expected distribution for the ftre duration. The procedure and jugtification follow thoge explained in Reference 34.

A aimplified achematic flow chart of the computer program uged to predict the fire-duration distribution is shown in Figure 10-1. Simulated accidents are limited to those where a fire occura* auch a 12 mitation greatly reduces the number of simulated accidents required for obtaining a good gtatistical sample.

A llgt of the major assumplione, ab well as the probabilizy distritutions uscd in the program, is given here. The assumptione and distributions we re obtained from a combination of qualitative and quantitative data; analytical models; enginecring spproximations; and, occasionally, intuition. $A s$ in the previougly discusged mode of transport (truck), wherever uncertainty exists the intent is to err on the side of conservatism; e. g. . to maximize the fire duration. Only fires causing over \$LO00 damage are considered.

1. Frequency of varlous firc-aceldent yypes are as shown in column 3 of Table IU-11. 


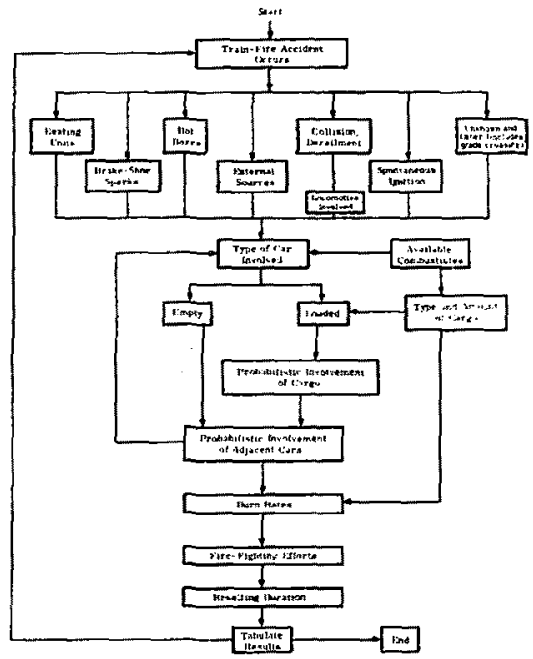

Figure tll-1. Fimplified now char: $x$ Wone Carto tmin-fireduration progeam.

2. As oblained from the aceident data. ${ }^{31}$ the digtribution of fire cauges other than collision and derailment are as follows: unknotm, other, and Erade crossing (27. 2 percent); spontaneaus ignition (2.1 percent); external sources ivandalism, etc, 27, 2 percem ; hot boxes (7.1 percent); brake-shoe sparks (28. 2 percent); and heating units ( 9.2 percent).

3. When collision resultg in fire, the locomotive is Invalved in the fire 26 percent of the time, 31,32

4. Coxears are involved in 72 percens of the fires. ${ }^{31}$

5. Loaded tank cars are involved in 14 percent of the tires. 31 .

6. Refrigerator and other cars are involved in 14 percent of the fires. 31 
7. Diesel fuet on board the locomotives ${ }^{35}$ varies from 1000 to 5000 gallons. wiut an expected value of 2000 gallons and a cumularive disfribstion function fedif aten by

$$
1-e^{-(f-1000 / 1415)^{1.05}} .
$$

where $F$ is fuel in gallons.

B. When diesel fuet from locomolives is involved in the fire, it is digpersed uritormly over 500 to $1000 \mathrm{ft}^{2}$, with an expected value of $700 \mathrm{rt}^{2}$ and a cdt Given by

$$
1-e^{-(A-500 / 252)^{1.6}}
$$

where $A$ is area in $i t^{2}$.

9. When ome car becomes fnvolved in a fire, the probability of adjacent cars (if nommable\} cotchirg fire is 20 percont.

10. Firty-six percent of the tretglit cars are loaded. 20.35

11. Five percent of the commodities earried in refrigerator and "other ${ }^{42}$ cars (not boxcars or tankers) are combustible. 29,35

12. Fourteen percent of the commoritics curried in boxcars are fammable. 24, 35

13. Average cargo weight of landed boxcarg is $\$ 6.7$ tons, with in distribution from 10 to 90 tons given by

$$
1-c^{-(W-10 / 44.6)^{1.89}} \text {. }
$$

where W is cargo weight in tons, 23.35

14. The traction of flammable goods in boxcars dat will burn raries irom 0 to 100 percent, with an expected value of 20 percent and 1 cdf given by

$$
1-e^{-(f / 0.268)^{1 \cdot 25}}
$$

where $f$ is Iraction that will hurn. 31,36

15. Char density of solld combustible cargo is 35 percent of virgin density. 19,20 
16. Iauded tank cars carry 100 percent nammables, with capucitles ranging from 10000 to 40000 andiong $\$ 5$ and a cdf given by

$$
1-e^{-(C-10000 / 17 t 42)^{2.11}}
$$

where $C$ to enpacity in gallons.

17. Tunk car tucl, when Involved, is spread unifarmly over as area vajing trom 600 to $5000 \mathrm{St}^{2}$. areraging $2000 \mathrm{ft}^{2}$; a cdt is given by

$$
2-e^{-(4-6,0051465)^{1.20}}
$$

where $n$ is area in $\mathrm{ft}^{2}$.

16. ineomotive ruct and tank-car contents habe a mass bum eatc ${ }^{14}$ of

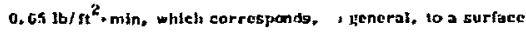
recession bum rate of $0.16 \mathrm{in.} / \mathrm{min}$.

19. For fucl purpoues, woos or other cellulosic material fn congidered to be representative of the solid tlammable material, with a represcntative hurn rate of $0.16 \mathrm{lb} / \mathrm{ft}^{2} \cdot \min$ for the first 30 mintuteg llincar Jecrease from 0.24 to 0,$0 ; 1 \mathrm{~d} / \mathrm{d}^{2} \cdot \mathrm{m} / \mathrm{n}$ ) and $0.05 / \mathrm{d}^{2} \cdot \mathrm{min}$ thereafter. 10,20

20. The boxcar nooring ${ }^{35}$ consiste of 2.25 inches of yellow pine or Dougtas If deeklng with a dengity of 35 tb $/ \mathrm{rt}^{3}$.

21. Freltghting ctiorta are avallable for all fires olarted from extersal sauroes folnes wis is moskly vendalism and occura in the raikyarids and for unc-third of the remainder of the lires. Ftrenghting is inetfecuve aguingt tanker-car fires,

22. Whon fircaghting efiortg arc avidiable and effective, Ire duration is controlled by the firelighting efrorts and is unitormly distributed between 15 and 60 minuted.

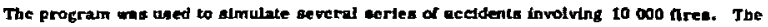

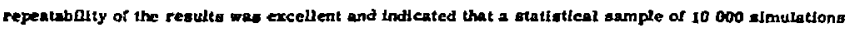
we anfficienty large to prevent veriations in the predleted daration digtribation of more then 1 poreent.

The resdits of the Mante Carlo prediction method are ahown in Figure III-2 as both a denalty Anculon and a cumulative distribukion tunculon. 


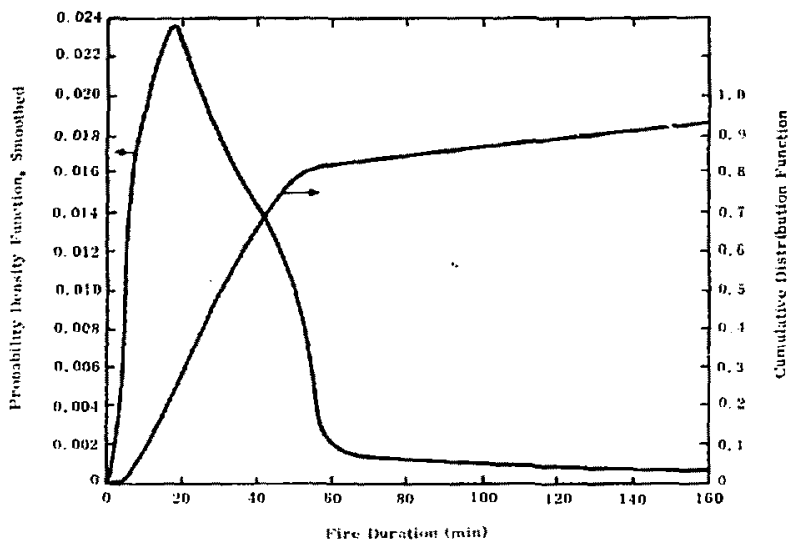

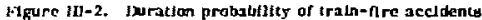
involving larke packages.

Although there are no data with which the regulis in Figure $11 \mathrm{l}=2$ can be compared, an inifrect and qualt tative comparison can be made with the distrlbution of property damage in fire accidenta. The limited dats from Reference 31 are shown In Figure 11]-3. Since Relerence 31 roports conly "average damage" valuce for each tjpe of accident, the average dollar walues have becn uniformly distributed by $: 75^{*}$ to prouluce the figure. As a qualitalfve comparjeon, llate points from the Monte Carlo duration predirtuon baged upon an arbitrary gealeng tactor of ster property damage per minute are shows. The arbitrary cost per tume value was aelected to place the nicoste Carlo dato polnte in the same region of the abscisga and thus show the qualitative comparison in the treads of the curve: it is not intended to be used as a predictive tool for catimating damage from tire timcs. Alubough such a predletion it vory artificial, Bince property damage is closely related to the infual value of the train and cargo, the comparison showa a definite qualstative correlation and adda crediblity to the duratlo:-predtetion method. 


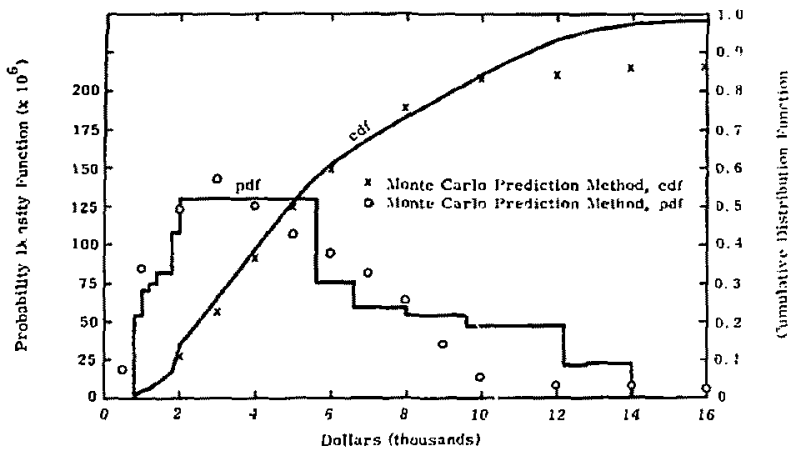

Ejgure tll-3. Dietribution of property damage trom rattroad fires.

\section{Conclusions}

Based on a train-acdient rate of onc every $10^{5}$ tratn mlles and taking tnto account the frequency of ratoce typos of accidents and the probable number of cars fnvolved, higurn 11 -4. which ahow the probabllty per car mlie of exceedlng any opecifjed duration firc environment, useg the tollowing beso: 31 The average number of cars involued in a fire following collision anaf or derallment is 10 and the average number of cars involved in "other" train accidents where fire occura ia 1.2 , regulting in a bre accident rate or $2.8 \times 10^{-8}$ car fire accidenie per car mile.

No attempt ta made in Egure 14h-t to addregs the quegtion of how trequently a large package will be exposed to the firc. It is corservatt vely estfmated that, given the fact that a package ja on a train, close exposure win ocour no more oftes that ance in every ten 11.es. Since 20 percent of the flres lnvolve only a single car and eince the heat nux dropg off very rapidy with digtance, 33 it would appear that the ouly poselblitles for direct package exposure would be (1) following a gevere coltiation and/or derallment where geveral can are bunched together, (2) In a railyard when a fire gtarts in a car or care on a nearby parallel track, and (3) Following a grade-crossing accident Involving a iniluer track, with the train gtopjing and the package in the middle of the enguing in Almost any , ther fire accldent would likely offer very linte threat to the pachage because of the distance betwien the package and the fire. 


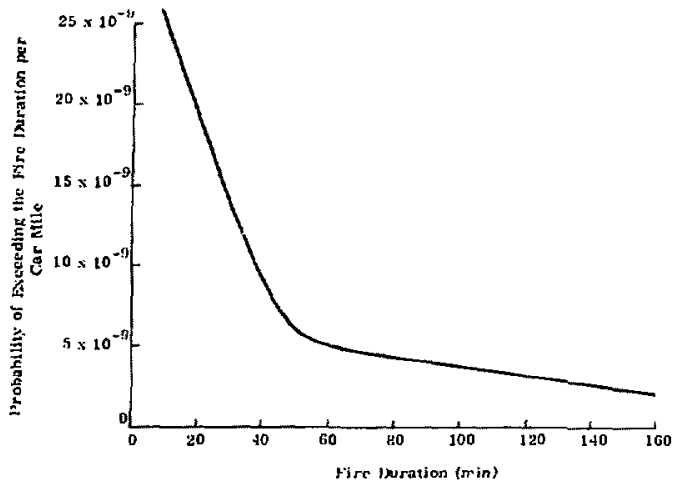

Figure IJl-4. Probability per car mile that a fire will occur and exceed the duration shown for train accidents. 


\section{Chapter 3 \\ IMPACT ENNIRONMENT}

\section{Introduclion}

The general proceture uned in this analysis is the eams as that weed in the truck transportation analyale. The principal difference lies in the reduced amount of detall avaijable in the rail -accident deecriptions. Two types of aceidents are tefined: the train derajlment accident and the train colletion accident. In the andysis, as th the truck analysis, it is the vehicie the ralles. ir this cere) enviromment that to predicted. The difference between railear impact and package impact is al gulficant for those containers that are more frail than the railcar structures. For cortainers that are atronger than zallcar etructures the abnormal cavromments predicted can be considcred as the package envircmmentg. An example of the latier condition can be found th the spent reactor fuol shipplng cask designed to meat the testing requirements of 10-CFR-71 Appendix B. In this casc. rallear eftects can be digregarded and the package can be thought of as cithes impacting an adjacent car or being impacted by an adjacent ear. It must be remembered, however, that railears are deformable gtructures, not rigid targeta.

\section{Derailment Analysis}

A computer program, which utilizes a Monte Carlo analysis technique, way prepared to study the derallment problem. A train with $66 \mathrm{carg}$ was utilized to modei the typical ohipment traln. I It was agsumed that the shipment ear was randomly placed in the irain. The lead car in the derailment was randomly chosen. One-hundred-thousand deraflme accidents were considered for each derailment distribution. In aach case, the velockty ehange of the ghiptnent car duc to impact, giver that the train experiences a derailment, is computed.

\section{Computatione of Velocity Change}

The procedure ubed for computing the velocity change of a ahipment car in a derailment accldent consibis of

1. Selecting the car of intereat randomly from the 66 freight carg in the troin.

2. Selecting randomly the lead $c a r$ in the deraliment group.

3. Selecting the apoed of the tradn randomly from the appropriate apeed distribution (Appendix E). 
4. Selecting the number of carg derailed (baeed upon the train velocity act: the derallment model used, Appendix E, Models 3, 2, and Is.

5. Determining whethes the car of interest is in the group of cars doralled.

6. If the car of interest ls not in the graup of cara deratled, recording a zere velocity change and proceeding to tha next accident simulation.

x. If the car of intereat is in the derabment group, computing its mogt sipoificant velocity change due to impact as rollows:

a. Geduce the preaceident velocity linearly, depending upon the car's deraflnient position in vite gtring of detailed cara. This is done by computing a car impaci factor (CtF) ag follow 5 :

$$
\text { CIF }=1-\frac{\text { car pogition number in deraflment }}{1+N \text { (number of cars derafled }}
$$

Figure III-5 is a graph of this function. It is known that the lead car in it derailment leaves the tracks at a velocity near the train's prederailment velocity. The car Jollowing the last car in the derallment group gtops on the tracks. Hence, becauge of the necessity for reducing the car velocity from preaccident velocity to impact velocity, a linear variation is chosen.

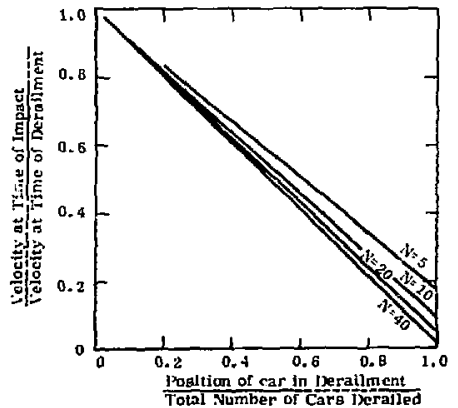

Figure ul-5. Car impact factor. 
b. Determine the severity of accident factor (SAF). Cara that leave the trackg in a derailment accident may or may not expcrience a signtficant collision. If they do experience a collision il may bo wh a gtanding car on an adjacen: track, a track gidu structure. another car in the derailmen* group, or similar objects. In onder to acconut for this, a geverity of axcident factor $w a g$ chooen ray. datnly from a uniform distribution on the 0-1 interval and applied to the derallment velocity to obcain a velocity change due to impset. Thla is a conservative assumption because it assumes that all de ralled cara will be fnvolved in some impact and, further, that moan value of this lmpact will be half of the maxdmum avallable inpact. velocity. This diatribution is shown in Figure IJI-6. The volacty change $6 \mathrm{~V}$ due to impact is computed as follows:

BV = (SAF)(CIF) (train proaccident velocity'

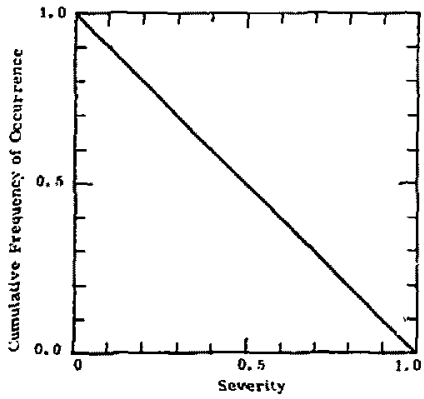

Figu we UL-6, Severity of accident factor,

8. The impact velocity computed is recorded, and calcutations proceed to the next accitent.

The reaulis of this derailment analysis, presented tn Table In-N for three different models, as discusged in Appendix E. have been converted to gl : the expected frequency of occurrence for a veloctty change equal to or leag than a given velocity change and plotted ae Figure III-7. 
IAM1: $111-12$

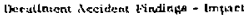

\begin{tabular}{|c|c|c|c|}
\hline \multirow[t]{2}{*}{ 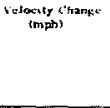 } & \multicolumn{3}{|c|}{ 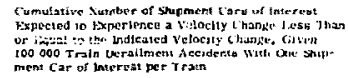 } \\
\hline & Hodel of & Mode $1 / 7$ & Mondst \& 3 \\
\hline to ecrailmen: & $: 0+\infty$ & 40211 & $5+1914$ \\
\hline 5 & ס55 & 15132 & $: 15461$ \\
\hline 30 & 9311 & +7152 & $\because \pi 50$ \\
\hline 15 & ?xisgos & 변도 7 & vitliso \\
\hline 20 & $\leq 4+463$ & ountifi & "xyti \\
\hline$=5$ & $2 ! 7011$ & 0,0152 & $56+5,4:$ \\
\hline 70 & $\therefore 5 \mathrm{ng} 7.3$ & 4250 & $4 \times 4 \times 755$ \\
\hline 35 & $\{91404$ & 94750 & n!atsis? \\
\hline 40 & $: 2+4)$ & stmato & $\pm x \neq x+4$ \\
\hline+5 & S & $5 \tan 26$ & $9+67$ \\
\hline so & 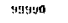 & :1955́ & $\ln : 146$ \\
\hline+5 & Santing & 69550 & $\{120 x+4$ \\
\hline 50 & otrosc & 9095: & 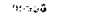 \\
\hline 65 & 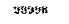 & เมืง9 & $x+4 \pm 13$ \\
\hline to & 100000 & 4!gya & 100000 \\
\hline 75 & & 100900 & \\
\hline
\end{tabular}

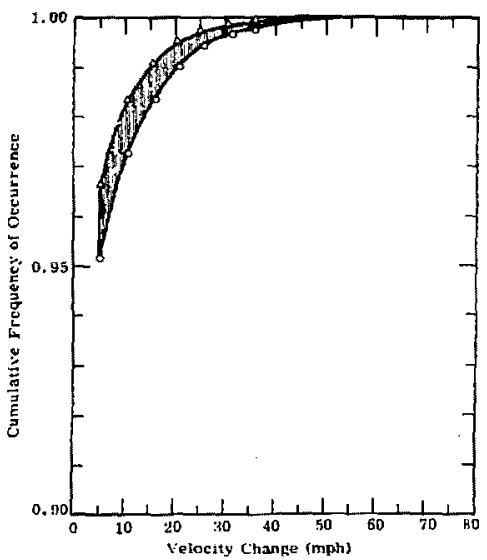

Figure 1[f-7. Traln derailment accldents, 


\section{Collision Analysis}

A computer program gimilar to that used for the derailment analysils was developed for the collision analysis. One-hundred-thouband computer simulated accidems were evaluated to determine the velocity change digtribution agsociated with the colligion enviranment.

The procedure for computing the velacity change in a collision accident cansists of

1. Selecting the type of colligion randomly based upon the colligion-accident distribution (Appendix F, Figure F-1).
a. Head-on colliator
b. Rear-end collision
c. Side or rakdng collision and collision with cora not in train (analyzed as iteadm on or rear-end coilsiong).
d. Broken-train collialors (analyzed go dervilmente;.

2. Selecting preaccident train velocitles for each traln in the collibion from the appropriate trafn epecd diatribution or select the derajlment apeed for broken-traln accidents from the broken-traln specd distribution (Appendix F).

3. For broken-train aceidenter, proceoding to the deraitmert analyais.

4. For collision accidenta, randomily choosing the train with the car of interegt.

5. Fandomly choosing the location of the train car of interest by car number.

6. Assigning collsion distribution molel to be used. Model 1, all cars lnvolved in colligion, or Motel 2, only damaged cars involved in collgion (Appendix E).

7. Calculating net impact velocity for the collthion by type af colligion. 
8. Calculating velocity change due to impacts. Calculation of this velocity change is bascd upon a linear reduction in net impaci . tlocity, as a function or car position, in a manner similar to that in derailnthut accidents.

The severity of accident factors is asgumed to be $1 \mathrm{~m}$ all collision accidents except broken-train accidents.

9. Proceeding to mext accident simulation.

The result of the colligion analysis. Frogented in Taule III- $v$, have been converted to give the expected frequency of occurrence for a velocity change equal to or less than a given uelocity change and plotted an Figure III-8.

TABLE UI-V

Colliston Accldent Findings - Impact

\begin{tabular}{|c|c|c|}
\hline \multirow[t]{2}{*}{$\begin{array}{l}\text { Velocity Change } \\
\text { (mph) }\end{array}$} & \multicolumn{2}{|c|}{$\begin{array}{l}\text { Cumulative Number of Shipmont Cars Expeeted } \\
\text { to Experience a Velocity Change Less Than or } \\
\text { Lqual to the Indicated Velocity Change. Given } \\
\text { 10D 000 Train Collssion Accidents With One Ship } \\
\text { ment Car of Interest per Train }\end{array}$} \\
\hline & Model $\not 1$ & Mtodel $\$ 2$ \\
\hline No collision & 12848 & 88409 \\
\hline 5 & 91276 & 96365 \\
\hline 10 & 91989 & 98000 \\
\hline 15 & 96112 & 98758 \\
\hline 20 & 97999 & 99197 \\
\hline 25 & 98926 & 99457 \\
\hline 30 & 99474 & 90658 \\
\hline 35 & 99699 & 99777 \\
\hline 40 & 90823 & 90841 \\
\hline 45 & 99894 & 99905 \\
\hline 50 & 99940 & 99946 \\
\hline 55 & 99971 & 99973 \\
\hline 60 & 99989 & 99989 \\
\hline 65 & 09905 & 99995 \\
\hline 70 & 99900 & 99990 \\
\hline 75 & 100000 & 100000 \\
\hline
\end{tabular}




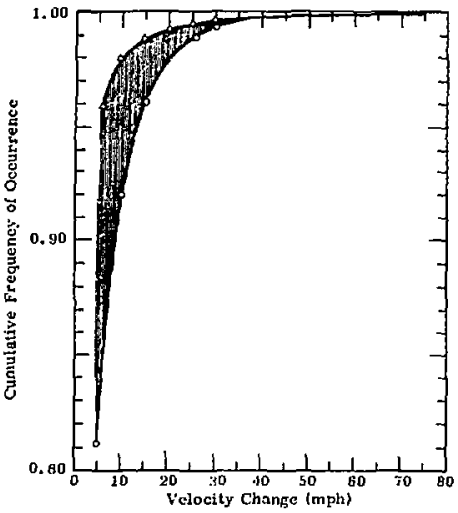

Figure III-8, Train collision accidents.

\section{Other Train Accidents}

No significent impact conditions have been found in this extegory. The catogory has been retalned in the analysis to malntaln compatibility with the accident rates used in Reference 1 . In the annlysig of the complete train accident (derailment, collision, and other), the car of interest 18 considered to suffer no velocity change attributable to "other" accidente.

\section{Train-Accident Analysis}

The term "traln accidents" refers to the accidents discusecd in Parl [It, Chapter 1, and listed in Table IjI-1. Amalysie of the train accident uged the derailment, colliaian, and "other" accident models digcussed above. There are six possible permutations of the thrce derailment and two collision models. The results of the simulation of 100000 train accidents, from the accident distribution shown in Figure E-1, are presented in Table III-VI Jor the upper and lower bound cages. These cases have been designated Case 1 (upper bound) and Cage 2 (lower boundl. Fygure III- 9 is a graplyc presentation of the data. 
TABLE III- VI

Train Accident Findings - Impac!

\begin{tabular}{|c|c|c|}
\hline \multirow[t]{2}{*}{$\begin{array}{l}\text { Velocity Change } \\
\text { (mph) }\end{array}$} & \multicolumn{2}{|c|}{$\begin{array}{l}\text { Cumulative Number oi Shipment Cars of Interest } \\
\text { Expected to Expericnce a Velocity Change Lesa } \\
\text { Than or Equal to the indicated Velocity Changes, } \\
\text { Given } 100000 \text { Train Acctdents With one Shipment } \\
\text { Car of Intecest pre Irain }\end{array}$} \\
\hline & Case 1 & Caae 2 \\
\hline No impact & 85077 & 91270 \\
\hline 5 & 94615 & $\$ 6924$ \\
\hline 10 & 97102 & 98395 \\
\hline 15 & 98301 & 09081 \\
\hline 20 & 98990 & 99489 \\
\hline 25 & 99386 & 99705 \\
\hline 30 & \$9631 & 99817 \\
\hline 35 & 99780 & 99896 \\
\hline 40 & $9987 B$ & 99943 \\
\hline 45 & 09935 & 99072 \\
\hline 50 & 99970 & 99985 \\
\hline 55 & 99943 & 99990 \\
\hline $6^{n}$ & 999g0 & 99902 \\
\hline 65 & 99995 & 99995 \\
\hline 70 & 99า97 & 99950 \\
\hline 78 & 99999 & 100000 \\
\hline 80 & 100000 & \\
\hline
\end{tabular}

\section{Conclusions}

The train-accident impact environment has been investigated, and the digtribution of the parameter governing the environments has been determined. The information contained in Table III-VI combined with the expected train-accident rate can be utilized to determine the expected Irequency of occurrence of a given velocity change due to impact. Far example, a 30-mph or greater velocity change is ensociatod with an expected rate of ocourrence of 1 every $27-m y l i o n$ package rail trangport mlles. The impact gituatione evaluated here are railcar environments. which may also be conservat\}vely assurged to be contolner environinents. With this method of analysis, velocity changes due to impact in a derallment accident or in a collision accident are treated as gimilar oceurrences. 


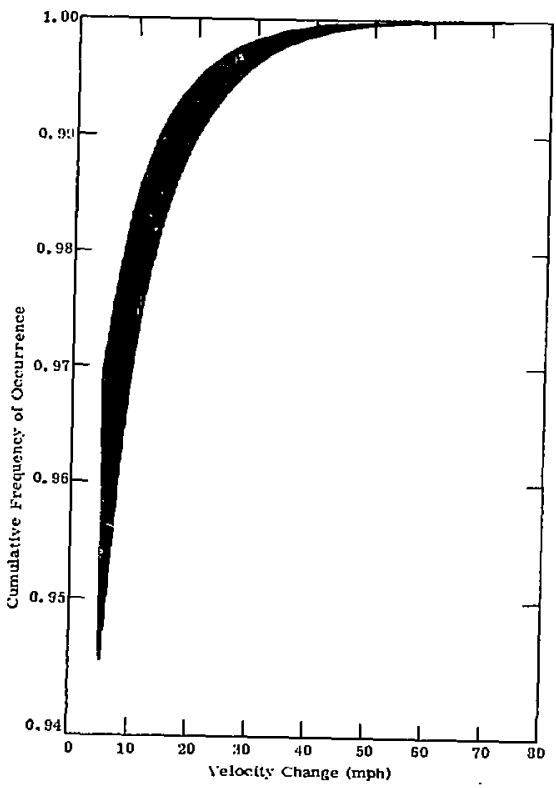

Flgure III-9. Train accidents, all types. 
PART III

\section{Chapler 4}

\section{CRUSH ENVIRONHENT}

\section{Introduction}

it is difficulf bath to define and to quantily the troin-cruah environment. As was noled in the truck eection of this report. the worl itself poseesses a rather vague connotation similar to a hydrostatic pregidure, but beknowledges that some degree of Jynamic, nonsymmetric load applica * tion is permigaible. We have, for this study, cather arbitrarily defined crush to be considered "the essentinly static forceb acting on a paskage as a 1 usult of $j$ ts position widemeath derailed cars." Agaln, the dytiamle loads involved in achioving this state are treated as impacts.

The degfred regult of tha analysta is the determination of the irequency, per mile of trangport " that a package will eneunter crushing forces and the expected severity of thege forces. The regults pregented in this acction are aimilar to those for the static crush portion for irains in SLA-7A-00D1.

\section{Crush Description}

The erugh environment is the regult uf a package reating between the ground and a derailed car or locomotuve. In our consideration of crush, ather cargo is neglected except for the dis trlbuted load it applies to a deralled car whon the package regts bencath that car.

\section{Frequency of Static Crush}

To estimate the probahility of crugh, it is necessary to estimate the ruwbe: of de railed cars and the atze of the area whtch they occupy. To eatimate the number of derailed cars, dato were oblained from a mafor railroad on all accidents occurring on its mogt raveled line for the years 1071, 1972, and 1973. In this ample there are 83 derallments. The average number of deralled cars yergug trafs bpeed at derailmeit fa snown in Figure jll-10.

Obtaining data on areas occupied by derailed eara proved to be very difficult. The derailed accdent reports of the National Transportation Safety Board, however. somedimes contain diagrams that permlt this information to be inferred. The date shown in Table Ill-VIt were obtalned fror: References 37 through $4 I_{*}$ 


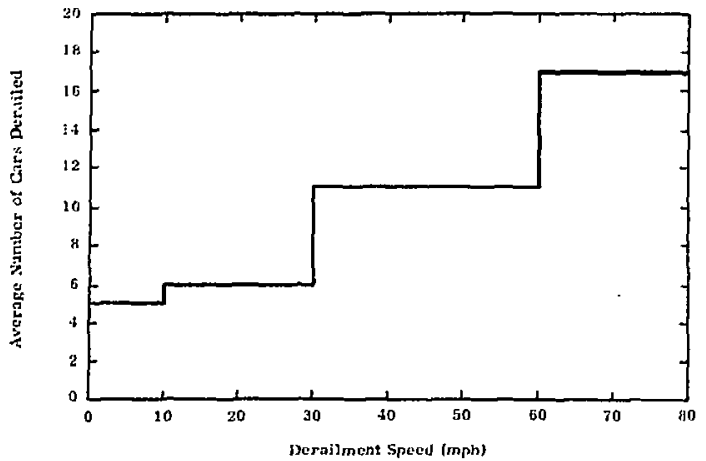

Fugure IU-10. Average number of cars deralled versus epecd at the time of derallment aceident.

TABLE IH-VII

Dimenatons of Areas Oecupied by Derailed Cara in Selected Aceidents

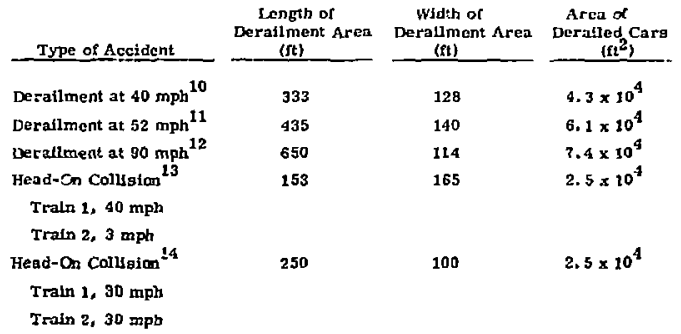

The data of Table UI-VI Indlcate that, for derallments, the length of the derailed car area Is very nearly proportional to speed. It is assumed for aralgais that the width of the demallad car arez is congtant (125 feet) and that the length varfes linearly from 100 feet at zeco velocity to 650 feet at $80 \mathrm{mph}$. For collualons, a constant area, independent of velocity, or $2.5 \times 10^{4}$ for two traing (1. $25 \times 10^{4}$ per train) will be gesumed. This assumption is based on data ghoim in Table III-VIL. 


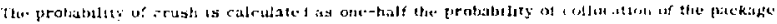

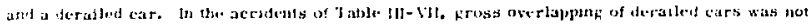

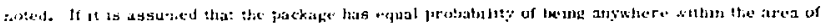

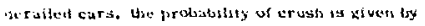

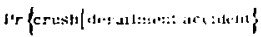

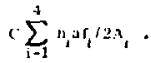

where

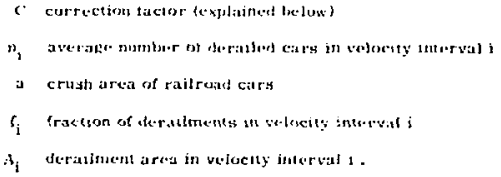

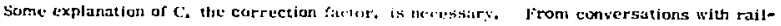
roat officials and from such acxident reports as teferencus 3 i Urough 41 , il appears reagonable to assume that it is mucl more difficult to pin a package bencath an upright car than beneath a car

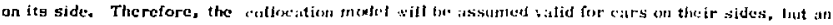
order of magnitude hiph for upright cars. The resulting vatue of $c$, whish must be applied to the

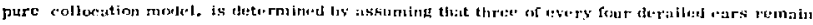
upriphl. 'This issumption Jeads to

$$
c=0.25 \cdot 0.75(0.1) \cdot 0.325
$$

The quantity " $\mathrm{q}$ " in Fquation (111. B) was ealeulated from car dimengions" weighted by the Iractioa of particular cer types in the eypical frelght train. These weighted areas, both for upright derziled cirs and for cars on their sitles. were nearly uqual, and $540 \mathrm{ft}^{2}$ was uset. The result for deraflment accidents was

$$
\operatorname{Pr}\{\text { crush|deraitment }\}=0.022 \text {. }
$$

for conisions, the analogous probabntty whs calculated from the equation.

$$
\begin{gathered}
\text { Pr \{crugh\}collision with deraitment\} } \\
=C \sum_{i=1}^{4} f_{t}\left(n_{t} a+n i n\right) / 2 A_{i} .
\end{gathered}
$$


where

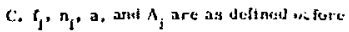

$$
\begin{aligned}
& n_{i}^{\prime} \text { namber of locomolives deralled in velocity inlerval i } \\
& s^{2} \text { focomotive crush arca } 715 \mathrm{~s}^{2} \text {. }
\end{aligned}
$$

A typical avera.,e, " $A_{i}$ " in the case of collisiurs, $191.25 \times 10^{4} / \mathrm{ft}^{2}$, indeperdent of velocity. J6oth

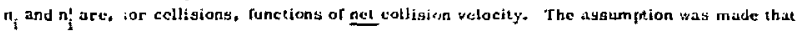

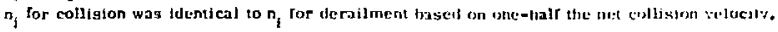

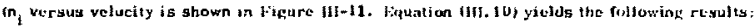

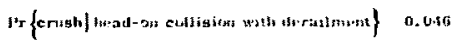

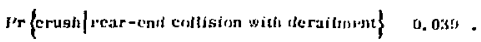

For broken-train collisians, the sane basie procedure was uged. Jht assumptions wero as follows: Al) same number of eara tso locomotives ficrailed versug velocity as for pure derailmonig and (2) $A_{1}$ - consiant - $2.5 \times 10^{4} / 2$ ay for colligions, rlic result was

Pr $\{$ crush| uroken train cetlision with teritimeta $\} \quad 0.042$

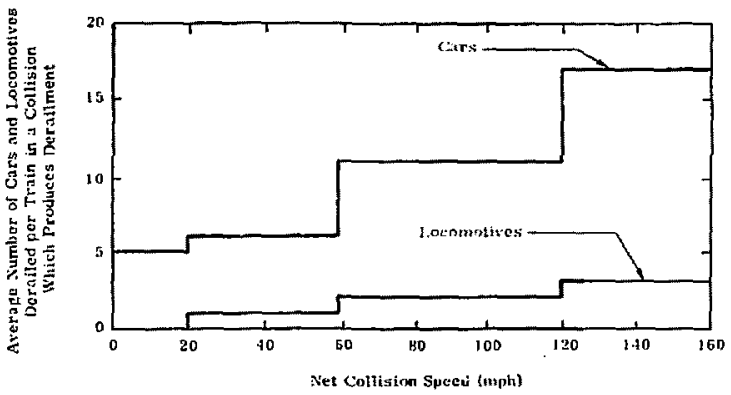

Figure 30-11. Average sumber of ears and locomotive serailed per traln in a collision that produces derallment as a function of net collision speed.

\footnotetext{
"Thlo askumplion bag: in diecuaged th greater detall in SLA-74-0001."
} 
collisions of trains or cart, with wars got in trains, is molketed exielly as rear+ond collisions:

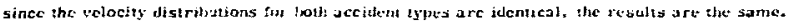

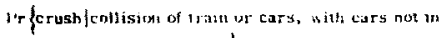

$$
\begin{aligned}
& \text { trains, with derailment } 0.034 \text {. }
\end{aligned}
$$

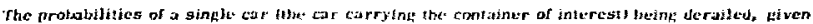
that derailment accurs on the trein, are calculated sith the equation

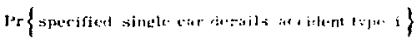

$$
\begin{aligned}
& \sum_{j=1}^{4} \frac{r_{j}^{n}}{x}
\end{aligned}
$$

where

i index on spegd interval four inceruals used)

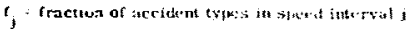

$r_{j}=$ iverage nunber of derailed cars ar aceirlent tepe in apeesl interval $j$

$S$ tolal number of ears in typical freight trains $(66)$.

When these calculations are performed, the results are

$$
\begin{aligned}
& \text { I'r }\{\text { singte cat de rails /derailment }\} \text {, 0. } 103
\end{aligned}
$$

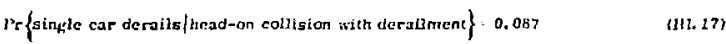

$$
\begin{aligned}
& \text { Pr\{aigle cur deraile|rear-end collision with derailment or collsiun } \\
& \text { of train or car, with car not in train, with derailment }\}=0.080 \\
& \text { Pr }\{\text { single car detollefbroken-train collision with deraiknent }\} 0.093 \text {. }
\end{aligned}
$$

with Uie above probabilitics, th is now posgible to calculate tie probability of erush. Iiven the various accident typeg. It is assumed here that all probobilitick calculated for head-on colliaions are valid for sldc or raking colltgions that oceur from a head-on direction ard similarly for rear-end collisions. It is also zssumed that side or rakine collisions are equally divided between head-on and rear-cnd directions. Al probabilitica a re presented in rabic lil-1/il, along witl the final resuits. 


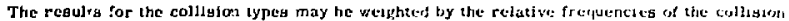

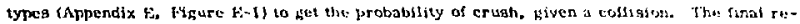
eults are

$$
\begin{aligned}
& \text { Pr }\left\{\text { statle crugh \{derallment accident\} } 2.2 \times 10^{-3}\right. \\
& \text { Pr }\left\{\text { stutic crushleallinion accident } 1.5 \times 10^{-3}\right. \text {. }
\end{aligned}
$$

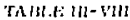

\begin{tabular}{|c|c|c|c|c|}
\hline $\begin{array}{l}\text { Traln } \\
\text { Mecident } \\
\text { Type }\end{array}$ & $\begin{array}{l}\text { J'fis:railnump } \\
\text { dccident rypu }\end{array}$ & 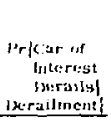 & $\begin{array}{l}\text { Frfsitatic } \\
\text { Crugh| } \\
\text { container } \\
\text { relcaged }\end{array}$ & 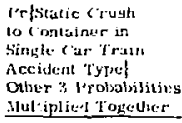 \\
\hline I Kerailment & 1 & 0.1 & 0.022 & $2.20 \times 10^{-3}$ \\
\hline $\begin{array}{l}\text { Ilead-On Collision; } \\
\text { Slde or Itakinf; } \\
\text { Colligion in } \\
\text { Head-On Irirection }\end{array}$ & $0 . \therefore 1$ & 0.0117 & 0.016 & $1.14 \times 10^{-7}$ \\
\hline $\begin{array}{l}\text { Rear-bud Coltision: } \\
\text { Side or Raking } \\
\text { Colliston in Rear- } \\
\text { Mnd Li reetion; } \\
\text { Colliston of Train } \\
\text { or Cars. With Cars } \\
\text { Not in Traing }\end{array}$ & 0.36 & 0.080 & $0.03 n$ & $1.12 \times 10^{-3}$ \\
\hline $\begin{array}{l}\text { Broken-train } \\
\text { Colligions }\end{array}$ & 0.36 & 0.003 & 0.042 & $1.41 \times 10^{-3}$ \\
\hline
\end{tabular}

Calculation of I'robubilitieg of Cirush. Given vartous kecirient ryject

This calculation makes the asgumpuon that the package will hreak the tierriwn restraintg and frce itgelf from the rallcar. The altcrnative behavior that could lead to a static eresh is urat the packnge remains integral with the railear, and the final position is with the car regting on the package. It has been estimated that one-rourth of the derailed cars overturn. Or these. it is improbable that more than one-tenth of the cars are wheels-up at the end of the encounter. This suggests an upper limit of 0.025 for the crush probability if the container is retalned. This condition is comparable to the 0.022 to 0.046 values ahown in Table ID-VIJ. The concluaion is, theretore, that no major difference in crugh probability should be expected whether the large package stays with the rejear or is thrown free. 


\section{Crush Severities}

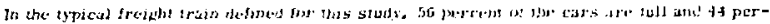

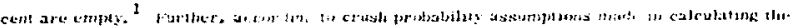

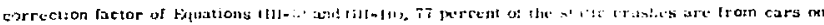

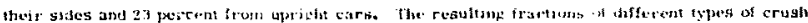

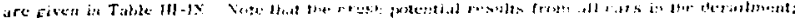

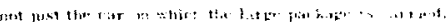

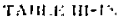

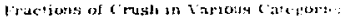

\begin{tabular}{|c|c|c|}
\hline & Irmpec & Fulu \\
\hline sat on sirke & 0. 14 & 10.13 \\
\hline C:tor | priflath & 0.10 & 0.1 \\
\hline
\end{tabular}

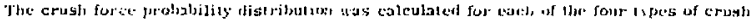

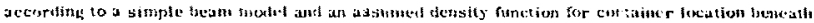

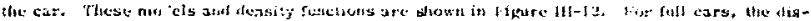

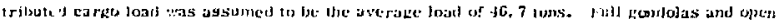

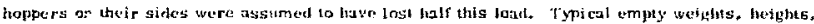

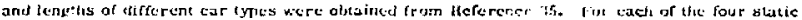

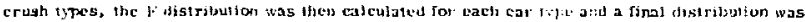
oblained by weighting each car distribution by the fraction of that car in the typical freiglue trais. llesults of these caleulations arc siown in ligure III-13. When the disiribution: wigure IJI-1/3

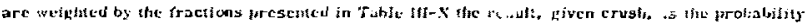
of a given erush load. This resull is shown in lirure $111-1$ t.

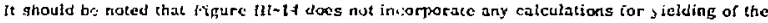
car structure. For atalic erush bencath upright cars, because the underframe or the car is capable of supporting the lazds calculazed, no error occurs fram thit source. For crusli from cara or their sides, however. there will be some container lowh. depending on container position. where the gide of the car will deform significantly and not be able to exert furlicr force on the container. Therctore, the cumulative force distrtbulions for ors on their sides are conservalively high, as Whey do not incorporate this effect. In gondolas and open hoppers, because the reinforcing hat sections arc vertical, they do not proide much strength in bending about a verlical fwith respect fo the carl neutral axis when the car is on its side. Furthermore, won though the sides of these car types are very rigtdy attached to the underframc, they have no similar rigid roor attachment and Lheir sides are therefore more susceptible to bending. In view of the many assumptiono incor porated into the entire static crush analysis and of the complexity of folding the yield calculations correcly into the force diftribution, these calculations were not folt to be worth whilc. Neglect of this effect makes the erush force predictlons higher than expected. 


\section{Conciusions}

It hag been estimated that t: - probubility of any container in a rail shjpment being gubjectect 10 a alatic cruah laad is about 2. $420^{-3}$ per cor aceident and that the suverity of these loado is equal to or legs than those given in Figure 1II-14. When these values are combined with the probabluity of a rallear heing involved in an accideni por mile traveled, it it seen that the probabillty of a conta iner expericncing any static crush laad in excegs of, for example, 200,000 pounds in legs than $10^{-51}$ per war milk. 


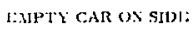

fleam Configuration

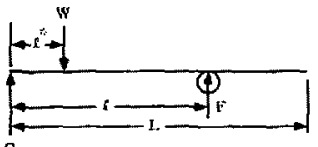

1.1. 11120. S[t)I:

130:4m Confinuration

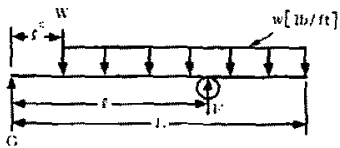

\footnotetext{
$\therefore$ antininer force

a k romang bares

$W=$ empty iar weight

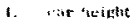

$i=$ coupler height
}

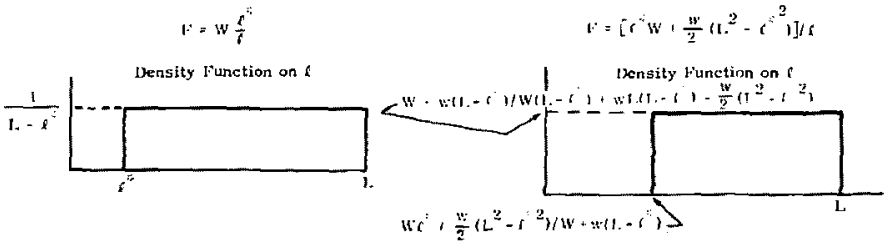

BIPTY CaR UPIRIGIT

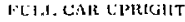

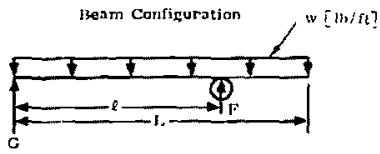

Oerm innfigurstiun is ialenticul to "empty" car tipright" except thiut th is distributed

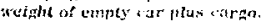

Densily Panction an $f$ is identical to "conpty cur uprishtit."

$$
\begin{aligned}
& F=\frac{w E^{2}}{\overline{u F}} \\
& \text { F * combiner force } \\
& r=\text { ground forct } \\
& W=\text { elistributed empty car woipht }
\end{aligned}
$$

Density Function on

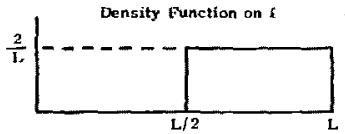

Mgure ID-12, Beam configurations and container location density supetione for crubly types. 


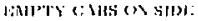

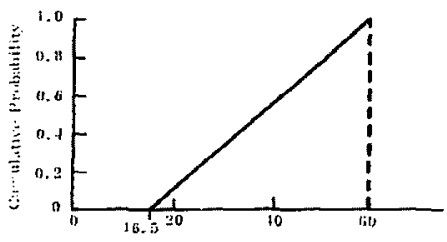

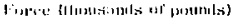

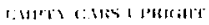

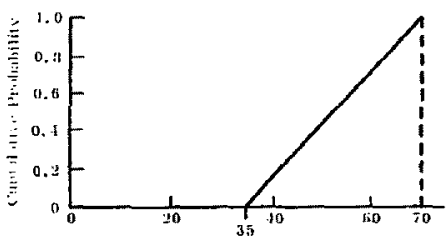

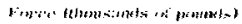

1.T.J. coles os silb:

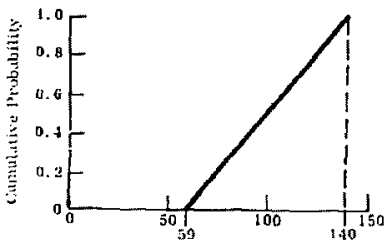

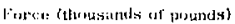

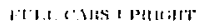

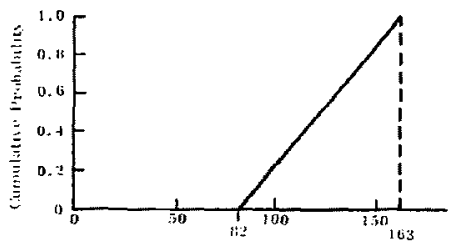

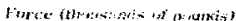

Figure IL-13. Cumulative F distribuliong for typea of crush.

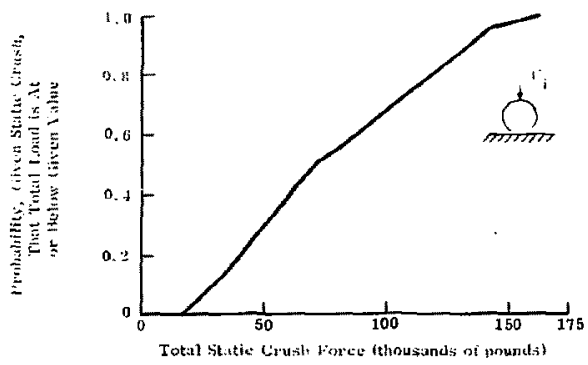

Fifure IIf-14, Cumulative digtribution of total erush load. 


\section{PART III}

\section{Chapter 5 \\ IMMERSION ENVIRONMENT}

\section{Introduction}

Immersion as an accident environment is defined in Clapter 1 of Part III. As explained in Rcforence 33 the environmental parameter carsirlered is jyctrostatic pressure, which is irterchangealble with depth,

Immersion resulting from a rail accident is an occurrence for which insufficie $t$ accident data are avalable. Through usc of indirect data, however, one potential imnersion accident can be modeled to give a perspective with regard to its probability or occurrence ond immersion depth. With regard to immersion duration, no inlirecl data presenlly appears to be avaliable wisich would lead to reasonalile estimations. 55,56

\section{Immersion Probability Model}

The immersion accident considered is that which occurs as a result of car derailnent off a brigge that crosses a principal stream. If it is assumed thot a train accident is as probable on a bridge as on any other section of main track. then an estimate for the probalility of an accident on a bridge, given an accident, is the quotient of bridge mileage spanning principal rivers divided by the total raflroad line mileage. The total mileage for the 33 major U. $S$. rallroad uridgea is 3.7 milesi $^{22}$ total rajlroad line mileage is 204 o00 niles. 29 Niultiplying this quotient by an arbitrary factor of 5 to account for bridges over main rivers and streams not ineluded in the major 33 gives the following result:

$$
1^{2} r\{\text { accident on bridge } \mid \text { accivent }\}=9.0 \times 10^{-5} \text {. }
$$

where the notation of a vertical separation litie indicatcs the rord "given."

Since it is assumed that only derailed cars can be immersed, it is necessary to calculate the probabiluty of deraliment, given the various accident types (Table IL-X). The probability of immeraing a gingle car, gfven that it is deratied on a bridge, Is assumed to be 0.25, as some deralled cars will naturally remain on the bridge and some will be restrained by the bridge Btrutcture. 
TAHI.E [H]

Cialculation of izrobabitity of immersing a Single Car. Given Various Accilent Types

\begin{tabular}{|c|c|c|c|c|c|}
\hline $\begin{array}{l}\text { Traln } \\
\text { Acctden: } \\
\text { Tyte }\end{array}$ & 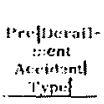 & $\begin{array}{l}\text { l'rfsingle Car } \\
\text { lerailes! } \\
\text { lectilment }\end{array}$ & $\begin{array}{l}\text { Pr|single car } \\
\text { Immersed| } \\
\text { twe rail on } \\
\text { Bridect }\end{array}$ & 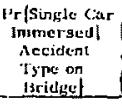 & 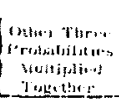 \\
\hline Deratiment & 1 & 0.103 & a. $2 s$ & \multicolumn{2}{|c|}{0.026} \\
\hline $\begin{array}{l}\text { flead-On Collislon; } \\
\text { Side or Making } \\
\text { Collision in lleatl- } \\
\text { On Uirection }\end{array}$ & 0. 16 & 0.0137 & 0.25 & \multicolumn{2}{|c|}{$0.007:$} \\
\hline $\begin{array}{l}\text { Rear-tind Collision; } \\
\text { Side or thaking } \\
\text { Colligion in Rear- } \\
\text { Entl Direction; } \\
\text { Colligion of Trains } \\
\text { or Cars With Cars } \\
\text { Not in Trains }\end{array}$ & 0.36 & 0.080 & 0.25 & \multicolumn{2}{|c|}{$0.007 \%$} \\
\hline $\begin{array}{l}\text { Broken-Tiain } \\
\text { Collisiorat }\end{array}$ & 0.36 & 0.043 & 0. 25 & \multicolumn{2}{|c|}{$0.004 h 4$} \\
\hline
\end{tabular}

The colculations outlincd in Tahic $1 \mathrm{U}-\mathrm{N}$ give the collowing tesults:

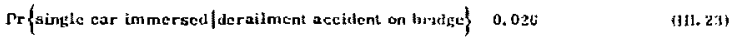

$$
\begin{aligned}
& \operatorname{Pr}\{\text { single ear inmersed fuerailnent }\}=0.026 \times 1.0 \times 10^{-5} \\
& =2.3 \times 10^{-6}
\end{aligned}
$$

When the peolabilities for the three eategories of collision accidents are welghted by ujeir frequcncies of occurrence, given a collision, the following numbers result:

$$
\begin{aligned}
& \operatorname{Pr}\{\text { single car immersed } \mid \text { collition on bridgc }\}=0.0075 \\
& \begin{aligned}
\operatorname{Pr}\{\text { single cas immersed } \mid \text { colligion }\} & =0.0075 \times 0.0 \times 10^{-5} \\
& =0.7 \times 10^{-6}
\end{aligned}
\end{aligned}
$$

The total probability of immersion. givon an aecident, may be found by multiplying probability

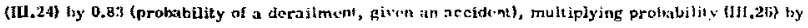
0.066 (probability of a collision, given a latio aceident), ant addiuk. The result is:

$$
\operatorname{Pr}\{\text { immeraion } \mid \text { accident }\}=1.95 \times 10^{-6}
$$


The average beldge lengh of the 34 najor ratl road bridies 22 is 500 fect. To calculate a depth diskribution, given immersion. xater depth was assumed as a fatiction or lenglh along the

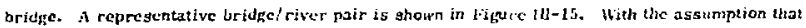
derailment resulting in immersion is equally tikely on any seution of the britge, the cutnulative

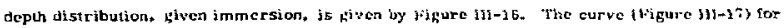
probability, per ear mile, of being immersed at a depth grealur than a tiven value nuy be

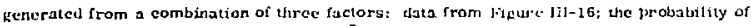

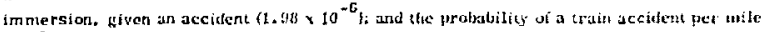
$\left(10^{-5}\right)$.

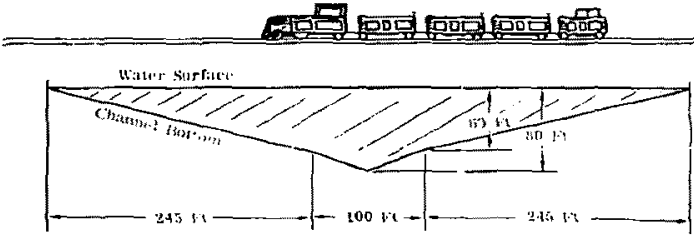

[igure l[1-15. liridge and river.

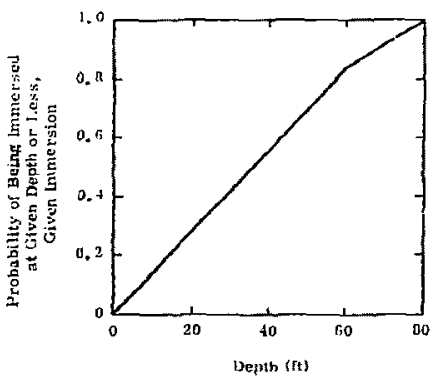

Figure III-18. Cumulative probability according to immersion dopth.

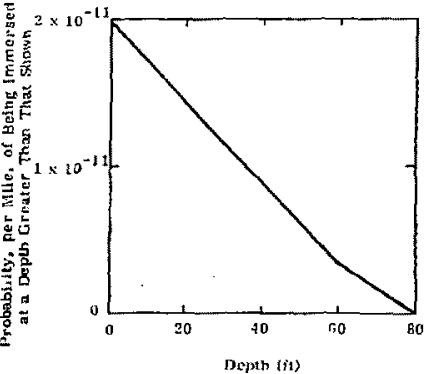

Fgure th-17. Probability, per ar mile. of being immeraed at o depth greater than that shown. 


\section{Conclusions}

The catimzted probabflity of immergion flue to accidents accurring on railtoad bridjes over Lcep rivers is $2 \times 10^{-11}$ per cor mile. When bepths are incorporated into the calculatian. Lie probabutty of excecthns a 50 -foot depth ig about $5 \times 10^{-12}$. Whough it is possible 10 enwision other types of accidents and aceidest locations that might regult in inimcrsion in rail accidents, theac are primarily ghallow wator accurrences and, at most, might increase thes $5 \times 10^{-12}$ figure $105 \times 10^{-11}$ per car or ile. If the rail briduc mileage were undereblanited here by a facter cif 10. the immercion probalyility vatue would still le less than $510^{-10}$ per ear mile. 
PART M

\section{Chapter 6 \\ PUNCTURE ENUIRONMENT}

\section{Introduction}

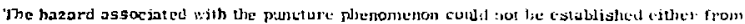

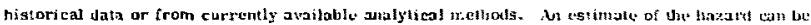

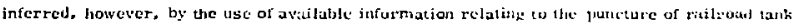
cars in train accidents. Although this type of accident has a towes requency Usas other tuil

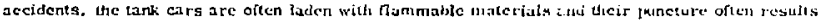

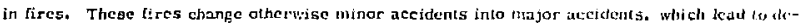
tailed accident investigation reports. References 43 througl th aro typical ruporis oj accideuls involving puncture.

The procedure used in the following presentatiot is one llaat is applicable to lic prabjalilistic cvaluation of a destar. th is always desirable to bave actual tost results avaliable for establishing the reliability of cach of the systeris components. In this cage citiniates of the reliabililies must be used. 40

The factors that control the punetur. inreat art:

1. Jifferential velocity of the cars at the time of impact.

2. Capacily of the probe so sustair impart looding withons signiricant mechanical lailure.

3. The equivalent thickncss lequivalent of mild steel in this case) of the item that is subject to prenet ration.

At this point it is necessary to consider d particular typo of item subjecied to the penetraticm threat. The item considered here is the large spcnt reactor fuel shippung cask. The casks contsidered are those meeting the requircments of $20 \mathrm{CPh}-11$ Appendix 13 . 50 Typical woighis are 20 to 150 tons. The casks aro generally engitucted of multiple concentric steel structural shells, with lead andfor depleted uranium shield materials between the shells. These casks provide a formidable target for any penetrator and the serength of the peactrator must be cunsitered in diw analyais. 


\section{Puncture Threat}

The following agsumptiong will be applied to the probo:

1. The coupler located $2 t$ either end of a rallear is representative of potential rafiroad puncture threats.

2. Coupler fallure sirenjth is a normally distributed raninm variatle.

3. Coupler failure occurg when the coupler/car connection ta broken and the incrial force of the car fa no longer trugsmiued to the cask through uhe coupler.

4. Coupler lasuling is directly related to differential impact velocity.

Degign of eouplers vary, Uut a representative coupler ypecification is the AAR M-J21 specifleation. 51 Specifieally, the differential velocity requirement is that the coupler car conncetion be able to autain a 14-1.ph impoct without car chmagu. It is usgumud for the first fallure model. Model 1, that csacntally no failures occur below a 14 -mph differental velocity and that egsentially all couplers fail at differential veiocities abuve $30 \mathrm{mph}$ unicss penctration occurs. The kinctic energy posuessed hy a car at $30 \mathrm{mph}$ in 4 . $\mathrm{i}$ times greater than that possessed by the car at 14 mit.

Figure tIf-19 is a plot of the agsumed nortsal probahilfty dersity function for the failure threshold velocity of car couplere when lmpacted agatrat masgive nonperforating targets. This is a plot of a normal distribution with a mear value of $22 \mathrm{mph}$ and a standard deviation of $2 \mathrm{mpta.}$ The prabability that the coupler will fall in a given fnterval equals the area contalned betwect any two velocity values. By integrating this curve, it can lir whewn that the probalbility or faflure helrus

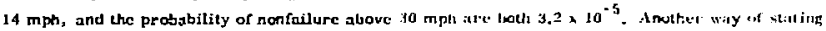
this is that 99. 9936 percent of all faidures are expected to occur between the 14- and:30-midu impaet velocities.

A sccond estimate, Model 2, was made by uging the 14-mph poirt at one end and doubling th: energy of impact at the high end. 1 is agsumed in this case, therr fore, that essealially all couplers fall between 14 and $42.4 \mathrm{mph}$ when striking a massive norperforating target. The kinetic nesergy of the ear travelling at $42.4 \mathrm{mph}$ is 9.2 times that or the car traveling at $94 \mathrm{mph}$. In this casc. the normal distribution is govarned by a standurd devation of 3.55 nph and a moan of $28.2 \mathrm{mph}$. The probabilty denalty function for Model 2 is ahown in Figare 1D-10. These two distributions are felt to be representative of the upper and lorer bounds of expected coupler strengths. 


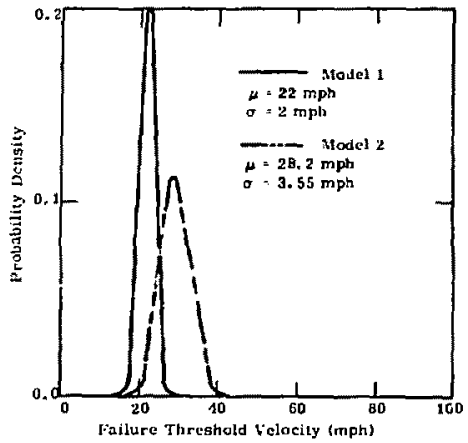

Figure III-18. As suned probabllity density funztlo.is for fallure threshold yelosty of traln car couplers Impacting masstve nonperforating targete.

\section{Puncture Resistance}

The next step in this problem to to develop an acceptable relationship between the puncture resistance of the tank car and that or a large shipplng contalner. Putcture sesistance can be gained in two ways. The first j6 physlcal separatjon distanee. The typtcal lank car has the tark head locates just above the tront/rear trusks with a nominal 2 to 3 feet between the car coupler and the tank hoad. ${ }^{35}$ Thus. when a second car overrides the coupler of the tank car, impact between the second car caupler and the tank head is certaln, even at low relative override veloc." itios (5-10 mplu). Figure IIt-19 is an example of such a condition.

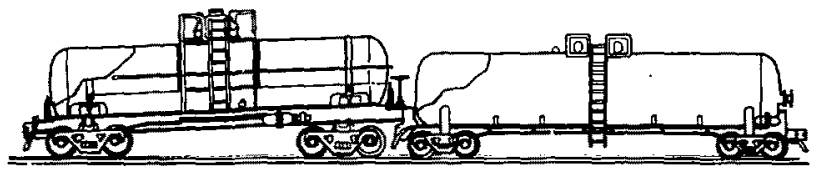

Figure III-19, Coupler overtide, Lank car collition. 
The length of a large packajte, guch as a gpent nuclear fuel shipping cask, ix always less when the raltear length. This leads to a gituation such as is ghown in frgure lil-20. Lr the case much higher relative velocitica are required for achicving impact between the coupler and the container.

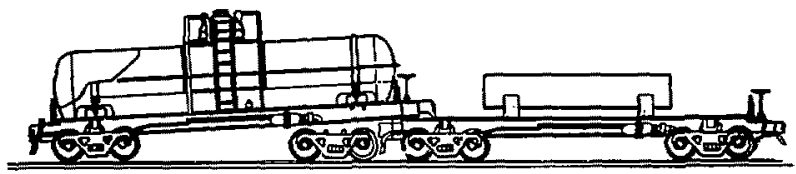

Figure IIf-20. Coupler override, Dachage car

This point te difficult to quanifily, but is ai fonficint ginec the mitority of lank car punciates reviewed are the result of override conditions.

The second factor that may be used to relate puncture resistanee of large cantainers to that of tank cres is the actud atructure to be penetrated. This can be done by estimating a minimum relative velocity to puncture a tank gar with a knoun wall theknesg and cstimating the relative velocity requirer for puncturing a conlainer with a differcnt wall thickness. A puncture analygis deyeloped in St.A-74-0001 was based on energy relation. This approach is uged in the eurrent andysis. Iquation (42) from Volume fit of $\$ 1.4-74-0001$ relates the approximate wall thicknesg nccessary to prevent punture to the impact veloclty:

$$
T=\frac{M}{V Y} \frac{V^{2}}{R}
$$

where

t is the thieknegs of the material gubject to puncture

A1 is the effective mass of the container

V is lie relative velocity between the probe and the container

$\Omega$ Is the radius of a probe with a circular cross gection that is equivalent to the actual probe

$Y \quad$ is the yield strength of the materlal gubject to puneture. 
For spent nuclear fucl ghipping casks, the weight of the eash and the weight of the wank car are comparable. The sictu sirengthe of the sice:s, farbon and staindess, ure algo comparable. Siner the probe under consideration is thr same for tank car and for cagk, the If teris is constant. Rewriting the above equation, we have

$$
r=\left(\frac{v}{a}\right)^{2} .
$$

The dimensfong used in this casc are:

$$
\begin{aligned}
& T-\text { inches } \\
& V-\pi p h \\
& \sigma-m p h / \sqrt{\text { inchos }} \text { (a constant). }
\end{aligned}
$$

The asgumptions made in obtaining Liqs. (tII. 2 H) and (III. 20) may be quastioned by some rcaders. Indced, it could be gltown that a number of factors not consivered above affect the nenetration of a givitn taryet by a given probe; however. floc purpose of the relationship is to obtain a value to be uged in an-ordec of -magnitude evaluation of Jie puncture threal and it should be used only for this purpose.

The constant $\alpha$ can be estimated for mild steel from existing tank car accident reports $37-41$ and typical tank car construction detalis. 35 From avalable accident reporte, it is estimated that - 25 may be uged for assured puncture of tank car heads and shells. It is assumed that 40 pcrcent of this valuc can be used as a puncture thresholu, Baged on this assumption, Jabie III-XI gives the estimated threghold velocities computed for puncture of packages.

IABLEE III-XI

Fotimated Junclure Threshold Velocity for Packages With Auld Stcal Wails

\begin{tabular}{|c|c|}
\hline $\begin{array}{c}\text { Lquivalent sild Stecl } \\
\text { Taget Thickness in. }\end{array}$ & $\begin{array}{c}\text { iveture Threshold } \\
\text { Telocity (mph) }\end{array}$ \\
\hline 0.4375 & 13 \\
0.50 & 14 \\
0.75 & 17 \\
1.00 & 20 \\
1.25 & 22 \\
1.50 & 24 \\
1.75 & 26 \\
2.00 & 28 \\
2.50 & 32 \\
3.00 & 35 \\
4.00 & 40 \\
5.00 & 45 \\
6.00 & 49 \\
\hline
\end{tabular}




\section{Probability of Puncture}

We can naw cotimate the probablifty of puncture based cither an (1) the absuraption that a puncture situation existe in every abnormal envirament impact situation or on (2) the assumption that a puncture situation exists asly in a Iraction of the impact situztions. The probability of puncture per train accident anj the probability of puncture per tranzpor milte can then be ealculated.

A zero-one step function probability is assumed for packafe-perforation resistance. If, for example, the impact volocity is equal to or fiseater than the pencteation the ghold velacily, the package ean ise perforated provided that the esinler does not fail. Lising (1) this assumption, \{2\}

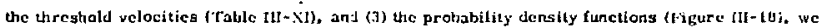

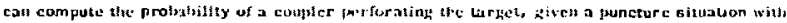
velocity equal to or arcater than pincture tireshold velocity. These probabilites are listed in I'able III-XII.

TA!H,E HI-XI!

Pubbability of perforation. Given a Iunclure situation with tise

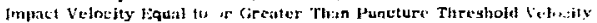

\begin{tabular}{|c|c|c|c|c|}
\hline \multirow{2}{*}{$\begin{array}{l}\text { Mijld stecl } \\
\text { Target } \\
\text { Thieknegs } \\
\text { (in.) } \\
\end{array}$} & \multirow{2}{*}{$\begin{array}{c}\vdots \\
\vdots \\
\vdots\end{array}$} & \multirow{2}{*}{$\begin{array}{c}\text { Perforation } \\
\text { Threshold } \\
\text { Velocity } \\
\text { (mph) }\end{array}$} & \multicolumn{2}{|c|}{ trolsalidity of t'erforation " } \\
\hline & & & Case 1 & Case 2 \\
\hline 0.4375 & & 13 & 1. & 1. \\
\hline 0.50 & & 14 & 1. & 1. \\
\hline 0.75 & & 17 & $9.9 \times 10^{-1}$ & 1. \\
\hline 1.00 & & 20 & 6. $4 \times 10^{-1}$ & 0. $0 \times 10^{-1}$ \\
\hline 1.25 & . & 22 & $5.0 \times 10^{-1}$ & $0.6 \times 10^{-1}$ \\
\hline 1. 50 & 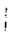 & 24 & $1.6 \times 10^{-1}$ & ข. $3 \times 10^{-1}$ \\
\hline 1.75 & ${ }^{7}$ & 26 & $2.3 \times 10^{-2}$ & $7.3 \times 10^{-1}$ \\
\hline 3.00 & ț & $2 y$ & $1.4 \times \div 0^{-2}$ & $5.2 \times 10^{-1}$ \\
\hline 2.50 & : & 32 & $2.9 \times 10^{-7}$ & $1.4 \times 10^{-1}$ \\
\hline 3.00 & $\xi$ & 35 & $4.0 \times 10^{-11}$ & $2.6 \times 10^{-2}$ \\
\hline 4.00 & 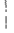 & 40 & - & $4.4 \times 10^{-4}$ \\
\hline 5.03 & & $4 \sqrt{i}$ & - & $1.1 \times 10^{-7}$ \\
\hline 6.00 & & 49 & - & $2.3 \times 10^{-10}$ \\
\hline
\end{tabular}

NOTE: a. This volue is the same as the probability that the couplur will nat fail giver an impact at or below the perforation threshold velocity. 
The velocities listed in Table ID-XII are baged on the asgumptione that one car is standing and the other is in motion at the stated velocity or on the aseumptions that the velocity fa the relative impact velactly and that both cars are in motion. These velocities were not directly available from the impact calculations: henec. a conscrvative asoumption is made. 19 is agsumed that the relative velocity at tmpaet is equal to the ear's preaccident velocity. The cumulative probablity of oceurfence of given veloeitice. as determined by the upper-bound impact madel. are Iisted in Tabie IH-XHI.

TABLI: JII- XIL

Car Ireaceident Valocities

\begin{tabular}{|c|c|}
\hline $\begin{array}{l}\text { Car Prelmpact } \\
\text { Velocity } \\
\text { (mph) }\end{array}$ & $\begin{array}{l}\text { Cumulative Probabilities of } \\
\text { Oecurrence of Car l'reimpact } \\
\text { Velocities }\end{array}$ \\
\hline 5 & $0.266^{9}$ \\
\hline 10 & 0.4220 \\
\hline 15 & 0.5587 \\
\hline 20 & 0.6700 \\
\hline 25 & 0.7600 \\
\hline 30 & $(., 3272$ \\
\hline 35 & 0. 1780 \\
\hline 40 & 0.9153 \\
\hline 45 & $0.941 \mathrm{H}$ \\
\hline 50 & 0.0603 \\
\hline 55 & 0.9735 \\
\hline 60 & 0. 9423 \\
\hline 65 & 0.9481 \\
\hline 70 & c. 5022 \\
\hline 75 & 0.9953 \\
\hline 80 & 0.9999 \\
\hline
\end{tabular}


With this informatios, the probability that a puncture situotlon will occur gfven a package 15 invulved in an impuct with a rall ear can be computed. The baste agsumption here is that al guch impuc:a will regult in a packoge-puncture gituation if (1) the relative velocity la above the puneture threghold velocity and (2) the probe (eopler) doss ast fall. The probsbillies calculates for the ase assumptlons are recorded in Table III-XIV.

\section{TAELE IU-XIV}

Probabilly That a Poientlal Packago Puneture will Oecur civen the Package is Involved in an Impuct with a kellrarl Car

Package Wall Thickness
0.4375
0.50
0.75
7.00
1.25
1.50
1.75
2.00
2.50
3.03
4.00
5.00

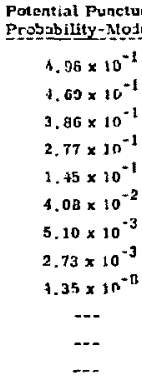

Potential Pucture
Probabilty:dujel
$4.96 \times 10^{-1}$
$4.69 \times 10^{-1}$
$3.95 \times 10^{-1}$
$3.26 \times 10^{-1}$
$2.79 \times 10^{-1}$
$2.24 \times 10^{-1}$
$1.62 \times 10^{-1}$
$1.01 \times 10^{-1}$
$2.10 \times 10^{-2}$
$3.13 \times 10^{-3}$
$3.70 \times 10^{-5}$
$6.30 \times 10^{-9}$

The expected fruquency of a puncture situation. Given a train accident, may ba estimated by ujing avaibblu data on lank-car punctuces, Referenes 52 in a sumnary of liz: mxjor raitroju accidents tnvestiguted by FRA during the perios July 1. 1971 through June 30, 1972 . Of thege. 110 were train collision sr derailmeat acsidents. Tho remaining 11 were rall-nighway fGradecrossing) accidents.

Of the 210 train zceidents, 11 involved the parforition of ong or more tank cars. Thesiz 11 accidents resulted in an estimated 81222000 uamage to rallroud property, or an zverage of $\$ 111000$ per accitent. The average cost per accident during 197,9 o 1972 wa $\$ 15000$ and $\$ 14300$, respectively. It is clear that these 11 accidents represcnt anjor failrusd acoidents.

Of the 110 accidents, 9 involved the perfaration of one tank car, one involved the pirforation of two tank cars, and axc involved the perforation of an indeterminate number between one and seven tank cars. The number is Indetermiriate because the report on this latter accident docs not

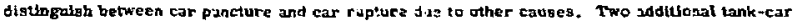
perforatiang during thlo perios have becn reported in Reference 53 . In each of these aceideris 
one car was perforated, Between 14 and 20 tank-car perforations werc reparted during this periot. It mast we asgumed that others oscurred during this same poriot, but that the reports of these punztures have not been found,

With this information the 1972 train mileage ${ }^{61}$ and the average number or tank caca par train (Table E-WW), the tank car pancture rate can be estimated.

$$
R_{T}=\frac{N}{n} \quad \text { tonk ear punciucos }
$$

Where

$$
\begin{aligned}
& \mathbf{N}=\text { number of tank-car punctures par year }=20 \\
& n \text { - average number of tank cars per train }: T \\
& \mathrm{M}=\text { train núleage per year } \quad=4.51 \times 10^{8} \\
& \mathrm{R}_{\mathrm{T}}=6.3 \times 10^{-9} \quad \frac{\text { tank-car punctures }}{\mathrm{ta}-\mathrm{k} k-\mathrm{car} \text { nije }}
\end{aligned}
$$

The expected exposure rate of a packnge to puncture can also be cstimated using: $\{1\}$ the train aceident rate. $10^{-5}$ pes trath nthe; (2) the probability of puncture tar $0.4375-i n$. thick mild stecl plate, 0.496: and (3) the rate of involvement of car in impacts given a train aceitisnt, 0.15.

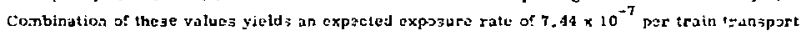
mile. The rate for pucturc glver a puncture situation can be estimated is follons:

Le: 8 = punctures par puncture situatio:

$$
\text { Then } \mathrm{p}=\frac{6.3 \times 10^{-0}}{7.43 \times 10^{-7}} \quad 0.47 \times 10^{-3}
$$

or $B \simeq 1$ puncturc in 100 exposures

It is likety that not all tank cars which wcre panctured furing 1972, the base pariot, are Included ir. the 20 congidered obore, It is aiso likely that no: all or the 20 puncturas reported were due to zoupler action, It will therefore bs assumed thut, by not radusing the liketihoof of punstare fue the differences in cospler overricle coaditions (Figures $t I m-19$ and 20 ) and also by using the upp:r-bound punstere Model Motel 2), the desired cosservatism is retained is the andysis. 


\title{
Equivalent Wall Thickness
}

The Hnol point in this anniysis is to determine an equivalent steel thelenegs for other muterlals. The numberit are based on the relative target cfriciencies of 1 -in, -thick plates in stopptng 100 -groin compact otcel projectiles. 54 The rallo uged was that of tha projectile implet cretgy required for perforating the ptete of interest to that required for perforating a mil山 steel plate. The relutive thicknegg results are, at best. firgt-order estimates and ghould be applied with coution. If a probjem ls particulariy sensitive to this value, a more detalled Inyestigation should be made. For eqtimption purposes, the cquivalent gteel thicknegg of various container material can be deiermined by

$$
\mathbf{7}=\mathrm{T}^{\mathrm{T}} \mathbf{m}^{\prime}
$$

where

\author{
$\tau_{\mathrm{g}}^{*}$ is the equivalent mild atcel thickness of the material \\ $T_{\text {In }}$ is the matcrial thickness
}

$\mathrm{g}$ is a constant for each material as liated in Table $11 \mathrm{X} \times \mathrm{V}$

\author{
TABLE III-XV
}

Congtants tor Equivalent Stect Thtckness Estimation

\begin{tabular}{ll} 
Material & \\
\hline 2024 T $\times 3$ Aluminum & 0.25 \\
Mild Stect & 1.0 \\
Copper & $t .56$ \\
Lead & 0.0625 \\
Tuballoy $c$ & 2.2
\end{tabular}

Hit is assumed that all materiol other than mild steel rests upon a subgtantial steel base.

b

Mild steel, for the purpose of this study, it defined as a carbon steel wiliz a publighed ylelu point below 60,000 psi and a Mrinsl hardness number of 150 or less.

CCast depleted uranium is somelime a xsed as a shleld material in the design of radioactive materials packagas, infomation on this particular materlal was not avallable in the reference document. 54 information avallable on Tuballoy, which can bo depleted uranium in anj manufactured form, is included here :ar eatlmation purposes. 


\section{Summary of Results}

The puncture gituation hag been defined in terms of railroad tank-car puncture acciderts. The analysio is limfted and is belicved so be conservative; however, in cages where puncture resistanze is a major factor and the rates lated in Table J[J-XV] ore not sufficient, an extengive tegk program may be revolred to estableh a puncture threshold value for a givea probe and pickage.

\section{THZLE II!-XVI}

Probability of Puncture

Package Wall

Thickness Probabllity per

(In,) Trangport Mile

0.4375

$744 \times 16^{-9}$

0. 50

$6.9 \times 10^{-9}$

0.75

1.00

1.25

1.50

1. 55

2.00

2.50

3.00

4,00

5,00

6.00
Probability per

Probablity ocr

Fepartable Accident

$7.41 \times 10^{-4}$

6. $80 \times 10^{-4}$

5. $85 \times 10^{-4}$

$4.90 \times 10^{-4}$

$4.18 \times 10^{-4}$

$3.37 \times 10^{-4}$

$2.43 \times 10^{-4}$

$1.52 \times 10^{-3}$

3. $15 \times 10^{-5}$

$4.70 \times 10^{-6}$

5. $51 \times 10^{-6}$

$9.11 \times 10^{-12}$
Reportable Collifion or Derallment Aceident
g. $23 \times 10^{-4}$
$7.67 \times 10^{-4}$
$650 \times 10^{-4}$
$5.44 \times 10^{-4}$
$4.64 \times 11^{-4}$
$3.74 \times 10^{-4}$
2. $70 \times 10^{-4}$
$1.69 \times 10^{-4}$
3. $50 \times 10^{-5}$
$9.22 \times 10^{-5}$
6. $16 \times 10^{-B}$
$1.05 \times 10^{-11}$

Probubllity per Accident where Probe Falture Controlg I.

1.

1.

- 99

0.96

0.88

0.73

0. 52

D. 14

0028

$+.+\times 10^{-4}$

$1.1 \times 10^{-7}$

$2.3 \times 10^{-10}$ 
APPENDIX A

COMAERCIAL MOTOR-CARRIER ACCIDENTS

(Relative Severities and Frequencies) 


\section{Appendix A \\ COMMERCIAL MOTOR-CARRIER ACCIDENTS \\ (Relative Sevcritics and Frequcncies)}

\section{Introduction}

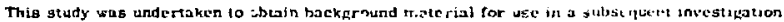

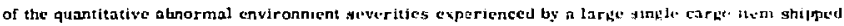
by commercial truck within the continuntal inited states. Thit study envestigutes the avaslable

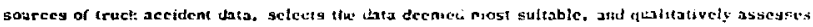

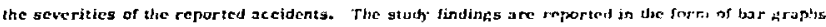
for quick visual interpretation and in tabulat form for use in subgequent studies.

\section{Truck-Accijent Data}

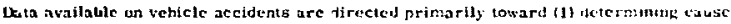
(2) coisnting fatalitics and injuries, and (1) det.rmintht economie loss. The severity of the accident as il relotes to eario tamase is not aduregsed in any of the state or wational velfiele acciucut re-

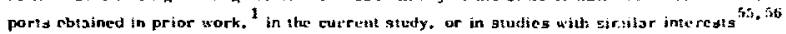
beinf, conducted at sandia taboratorice. I.eimkuhler ${ }^{5 i}$ employs available accident cost dala tu

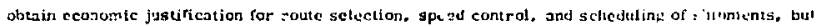

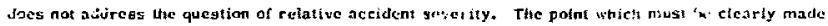

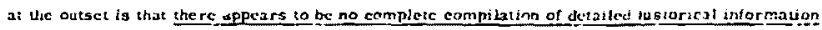
zceardine the crrects on cars o of real transportatisn accidents. Pessible crections 10 the siate-

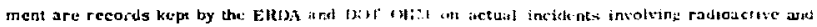

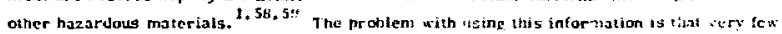

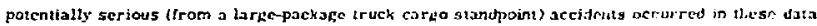
stets.

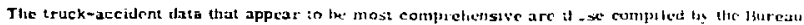
of Nator Carricr safety (HACS) in their annual repons, ${ }^{3-6}$ Bucs accident reporis tur lari?e (rucks were raviewed for the period 1168 through 1973. The 1969. 1970 . 1971 and 1473 b316\% redorts. which have a contistent accident definition, were usod as the primory data sources. The data contained in the Bacs reporta are digcusged ir detail later in this apperdix; at the outset, however. four rerificant points r.ust bu kept in mind:

1. BMCS Accident Reports do not include information dealing with vehicle speeds either creceding or at the time of the accident. 
2. Jeporting of aecidenis, required by law, if the reaponstbilty of the individuat carrier.

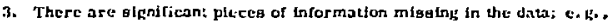
collibions with "fixed objecte" represient about 15 percent of all accidents. but no speciffe infortnation if given about the abjeets.

4. There is no generally acecpted nethod by which bMCS secidert reports can be correfiated with nolonal and or atatu aceident Btatistics.

\section{Basic Data Used in Analysis}

The dato bage (Haces Data) containcd intormation relating; to

1. Truck accident rates,

2. Fotalitics and injuries resulting from truck accidents.

3. Iollar coges associated with track aceldents.

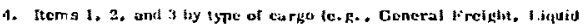
Fetroleum I'rodicts.

5. Truck-aceidem statistics by time of day and day of weok.

G. Truck-aceident statistics by ayc of tiriver (proventathle sceilents).

7. Items 1, 2, and a by type af accident (c. tow head-on colligion. truch with auta; truck collision with fixed objoct).

B. Items 1,2 , and 3 by geographic retion.

n number of ticse tiem development of procedural cuntrols (c.g., as related to type of eargo, time of day. day of week. age of driver, and geographical region), are not germane to this atudy.

The injury and falality rates pertinent to this study are those associated with the reporting vehicie's driver rather than the totals for given types of accidents. The items of especial signi * ficance are

1. Item 2, with spccilic reforence to reporting vehicle drjuer tnjury and fancity rates.

2. Item 3, dallar costs associated with each accident category.

3. Item 7, acciclents entegorized by type.

A truck aceident, as considered in this report, is either

1. A sin;tic vehicle accidnnt with the truck in motion; E.g., Funning of the road, overturming, and collstions with objects. 
2. A nutiple veticte areidsn with at thast one of the ualicless in motion: e.. L-. headton and rear-etyl collisions.

\section{Types of Vehicle Accident}

The Isucs reporta categorize large-truck accitenty th the maner dencrilued below:

\section{Collisitin}

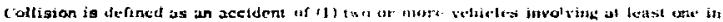
matton or ai a single veticle striking a stationaty object.

1. Hetestrian - Tle roparting truck is thwol ed in in sceitlent with $a$ pedestrian.

2. I'ruperty - ric reporting truch is invalvet in aul accident with a carrier of property icumineteial trueks.

flach of the zollowing is derined efiratarly)

3. Jassenger auto.

4. Notor Hus.

$\therefore$ Other Notos Vehicie (motor cyclut.

6. Hajil road train (frade-crossing accidenis).

7. Sirectcar.

H. 3i yycle.

13. Animal / animal-1 Jown vehtele

10. Fixed Objcct.

11. Other Object.

12. Laneported Objeet.

13. Itriveriess Vehicle.

\section{Noncolligion}

Xoneollision is defined 38 o gingle-vehele aceldent where the voluete is in motion.

1. Overturned on Road - The reporting vehicle overtumed.

2. Ran aff Roud - The reparling vehicle ran of the road.

3. Driverleas Vehicle - The reporting vehtele rolled away.

4. Oher Noncollision. 


\section{Gher heclulents}

In thits category the vehtele is not in motion.

1. Hure only.

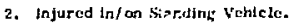

7. Fallen irom stunding Vehicla.

4. Thrown Afalnat Statuling Vehicle.

j. Stolen (slanding ) Vohjele.

G. vol bnewhere ("lusyirket.

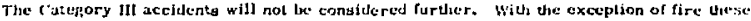

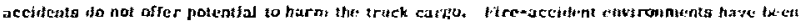

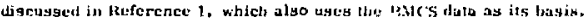

\section{Accident-Severity Measures}

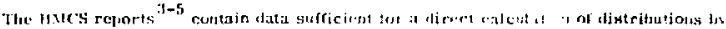

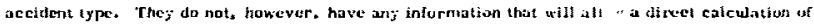

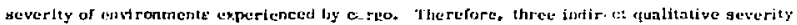
rncasures ire us[']:

1. The number of reporting wehtele ariver tatalities in each type of accident.

2. The number of reporting * vehlele drivers injured in each typt of accident.

d. The estimalicd tollar cost of the property damage in each type of accident.

The foregoing loformation can be uged to iniar the relative assident gevertly.

The following cocfficients defining distribution factors and irequencict are uged in th: severity calculations.

\section{Accident Digtribution Factor}

This is a ratio of the number of reported eceidents in a given clagsification to the total number of accidents roported.

Example: Categories I and II reported 170 070 accidents during the 1869-1972 period, Of those, 149 HOJ werc collision accidents and 29267 were noncollision aceidents. 
1...erce.

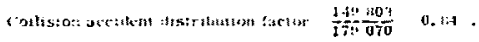

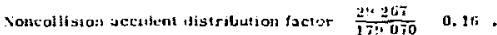

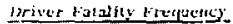

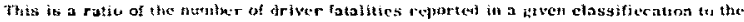

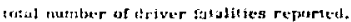

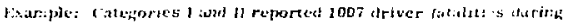

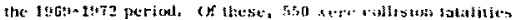

wyof $+5, \bar{i}$ werc nonewlision fattities.

ilenci:.

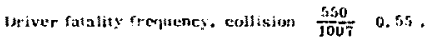

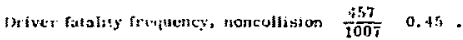

The foresoinf; cefcudations indieate that th percent of the driver fatalities oceurret in ofly

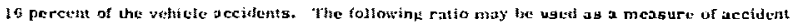
s?: verity.

$$
\text { Jriver fatality ratio } \frac{\text { Jriver fatalily frogutoney }}{\text { tecident distribution factor }}
$$

Fxample: For the above data,

$$
\begin{aligned}
& \text { Driver farality ratio, collision }: \frac{0.54}{0.84}-0.65 \text {. } \\
& \text { Driver fatality ratio, noncollision }=\frac{0.45}{0.16}=2,81 \text {. }
\end{aligned}
$$

It is learned, therefore, that only one aut of six accidents will be noncolltgion, but the driver is 4 times more likely to be killed in the noneolliaton accident than in the collialon accident. The inference dravin here ig that, as a group, noncollision accidents are potentially more dangerous to the driver than collision accidents arc. The injury ratios and cost ratiog, defined similarly to the foregoing tatality ratios, show the Bame trend. A severity retation by tecldest classification ean now be interred from the data. 
Wy enreying this concept further, one can compute soverizy ratios (latality, injury, and cost) for each type of accldent to fdentify those accidents that requi re detalled study. Table A*l is a year-by year complistion of vic aceident diatributions expreabed in terms of jercentages.

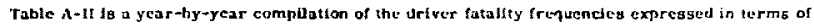
percentogea. Thege tablea ghow that the do th for the 4-year period beink consivered exhist a year-iomyear consiatency* Collisfor with passenger autos make un 50 percent of all movinf vehicle accivents each year and sccount for 10 percent of the fataltice each year, Accidents with rall rade trains account for 0.50 percent of the accidents and 2.5 to 3 percent of the falolities.

Table $\Lambda$-III is a year-by-year complation of the driver fatallty ratiog. Tabte A-IV is a compostlu compilation of the driver fachity ratios antl the accident cogi rating for the 4-yuar pertod. Table $A-V$ ie a compilation of the driver Injury ratios ror the game 4 -year period.

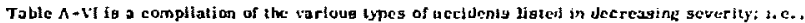
line 1 ig most eqvere and line $17 \mathrm{~kg}$ leagt hevere.

'The information shown in these tables is depicted grapisically in theures $A-1, \Lambda-2$, and $A-3$. Figure A-1 ia a plat of the normaljzed accident-severtig rating bastr an the truck ariver fatality ratio dertued for the 17 principal types of acefdents fisted in the collistion and Noncoltigion eatesoriug. Figures A-2 and A-3 depict the kame information hased upon truek driver Injuries : nd accident cost information.

It ia indfeated that several of the ftems can be combinel to reduce the number of eategrories that mugt be constuered:

1. Collibion whth fodestrian and collisiun Wilh hicycle art similar and will be combined (Jedestrian/ Bicycilc).

2. Collfatons with broperty (Truck), Motor ltes, and streetcar are similar and will be combined (Commarcial Truck).

3. Passenger Auto will remajn unchangod (Passonger Auto).

4. Colligion With Other Motor Vehicie (Motor yele) and Coilision With Animal/Animal-Drawn Vehicle have similar geveritics and will be combined (Motorcycle/ Animal).

-5. Rallroad Trains will remain unchanged (Grade Crossing).

5. Colltefon With Fbed Object, Collision with Unreported Ohject, and Colliaion With Other Ojbect will be combined (Stationary Object).

7. Rollaway/Colligion and Rollaway/ Noncollision will be comblned (Rollaway).

8. Overturn-on-Road and Ran-off-Raad are similar and will be combined (Overturn).

9. Other (moncolligion) will remain inchanged (Other). 
These conbinations are referred to as the lievised Aecident (atebories. Fuble A-I'th con-

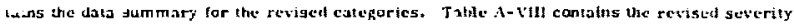

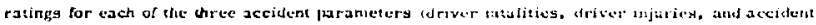

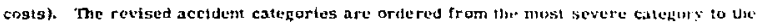
ICust scuere. Fitures $A-A$, $h-5$, and $A-6$ are fraphic representations of the nine categorieg for each of the three parameters. In the ae roprescitutions all the categorieg have beon nermalizhd by thivdinf the ratio associated with eack accilent catchory by the larpest ratin in its associated calegory. . '5ure $\lambda-7$ is a graphe represtentation of the frequency of decurrunce of the decident types.

\section{Conclusions}

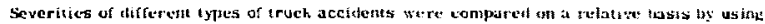
Irock driver fatality and injury isformation and accident cosl data. The accident severity ratings

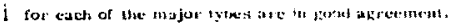

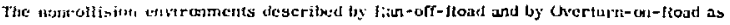

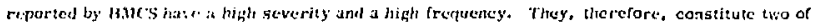

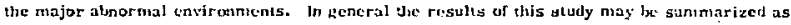
followi:

1. Iajlrand train collisions are very severc, but infrequent (about 0.6 percent of all accitientg).

2. Single-vehicle overturnity; ant running-oft-the-rond accitients are both very sevule and (requent (about 10 pereent of all aceidents).

3. Truck/truck collision accidents are less severe than the foregoinf, but occur frequently fabout 16 persent of att accidents.

i. Truck/passenger auto collision accidents do no:, as a sruup, provide a severe environment, but are the most frequent labout $50 \%$ of all acciden:sl.

5. The slaggifications Collision with a Stationary Object and Other (noneolision) are of moderate severity. are not wedt defined and are relatively frequent (about 22 percent of all aceidenta). 


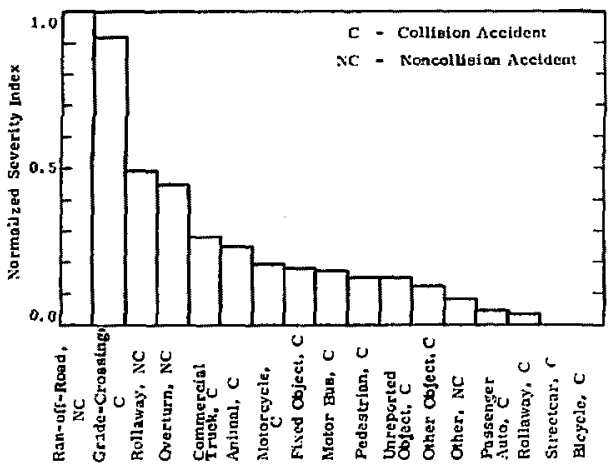

Figure A-1. Normalized driver ratality ratio.

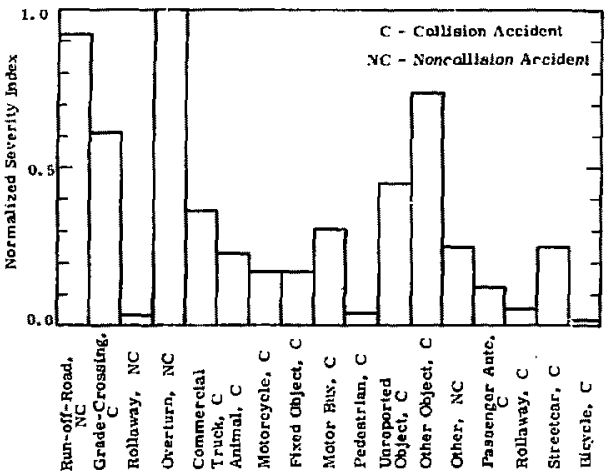

Ftgure A-2. Narmalized driver injury ratio. 


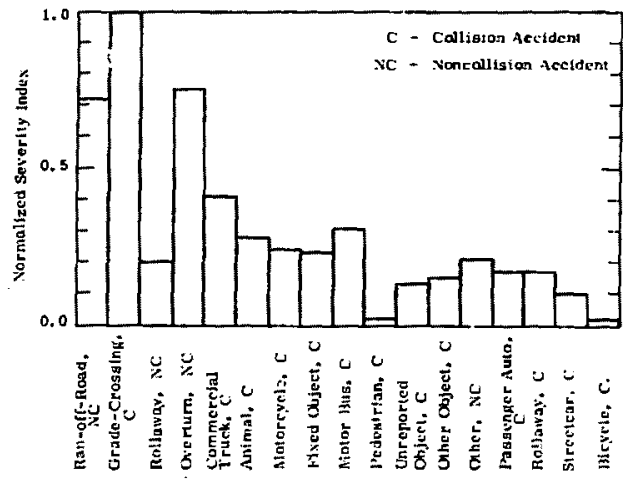

Firare A-3. Normalizod acrident cost ratio

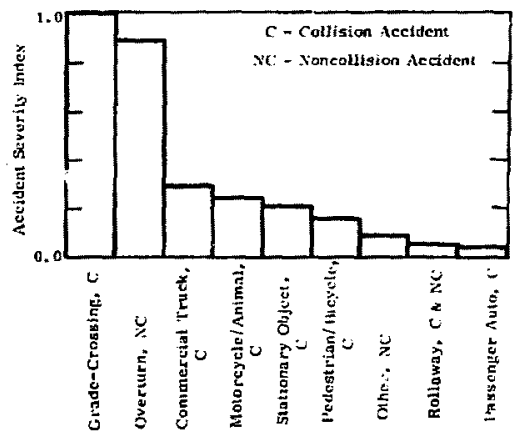

Figure A-4. Normalized driver falalty ratio for revised accident types, 


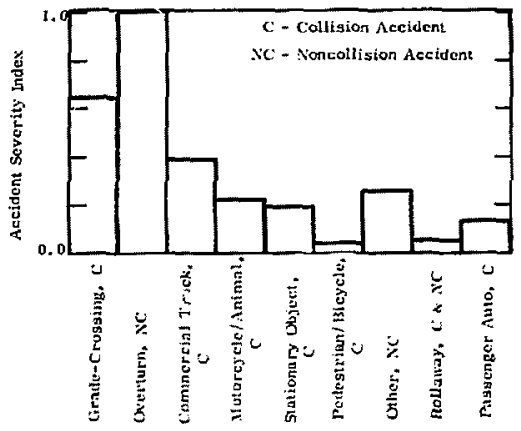

Figure A-5. Normalized driver injury ratio for reviated aceídent types,

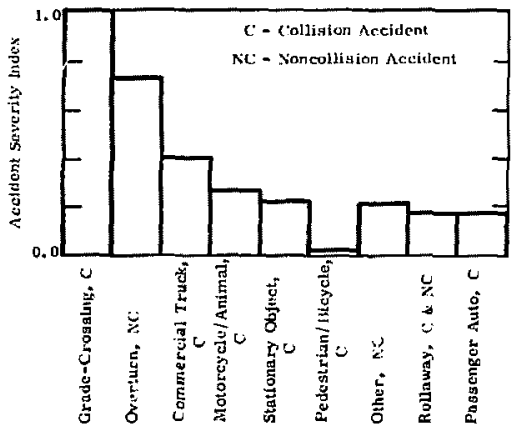

Figure A-B. Normalized accident cost ratio for revised accident types. 


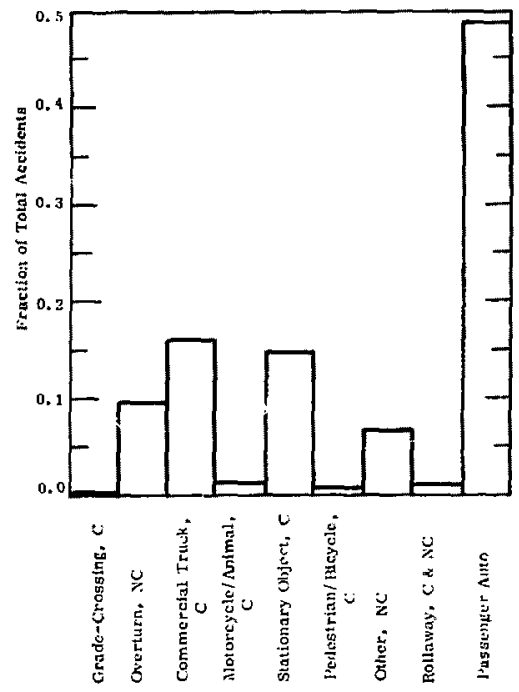

Pgure A-7. Accident frequency by revised accident types. 
TABLE A+1

Sumonary of Movtng Vehicle Aceidents, $1999-1972$ GMCS Reports

\begin{tabular}{|c|c|c|c|c|}
\hline \multirow[t]{2}{*}{ Aceldent Claggiocaition } & \multicolumn{4}{|c|}{$\begin{array}{c}\text { Percent of } \\
\text { Total Moutng Venicle Acedients Reporled }\end{array}$} \\
\hline & 1960 & 1970 & 1971 & $1 \pm ? 2$ \\
\hline \multicolumn{5}{|l|}{ Colligion whth } \\
\hline Padegtrlan & 0.99 & 0.84 & 0.84 & 0.06 \\
\hline Property & 15. 80 & 15.13 & 15.92 & 15.93 \\
\hline Pngaenger Auto & 47.58 & 40.54 & 48.22 & 47. 82 \\
\hline Motor Bus & 0.48 & 0,40 & 0.44 & 0.44 \\
\hline Oher alotor Vehicleb & 0.61 & 0.57 & 0.60 & 0.57 \\
\hline Rallroad Traln & 0.59 & 0,66 & 0.52 & 0.55 \\
\hline Streetcar & 0.01 & 0.09 & 0.00 & 0.00 \\
\hline Animal/Animal-Drawm Velilele & 0.80 & fi. 75 & 0.79 & 0.68 \\
\hline Etcycle & 0.13 & 0.11 & 0.08 & 0.09 \\
\hline Fixed Object & 14.04 & 14.02 & 14.59 & 15.07 \\
\hline Unreported Obfect & 0.11 & 0.14 & 0. 12 & 0.11 \\
\hline Other Objecl & 0.11 & 0.07 & 0.20 & 0.20 \\
\hline Rollaway & 1.38 & 1.29 & 1.05 & 1.03 \\
\hline \multicolumn{5}{|l|}{ Noncolltaton } \\
\hline Fan off Roadway & 6.87 & 6.89 & 6.40 & 6.47 \\
\hline Other & 6.02 & 6.65 & 7.33 & 7.17 \\
\hline Rolloway & 0.03 & 0.02 & 0.06 & 0.04 \\
\hline Overturn on Rond & 2.65 & 2.92 & 2.84 & 2. 8.8 \\
\hline
\end{tabular}

aproperty refera to medium and large trucks; thght tucks such as plckups, panels, and vans are classifled as passenger autos.

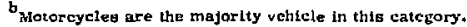


TAHLE A-U

Summary of Driver [rotalties for Moving Vehicle A teidents, 1960-1972 . MICS Reports

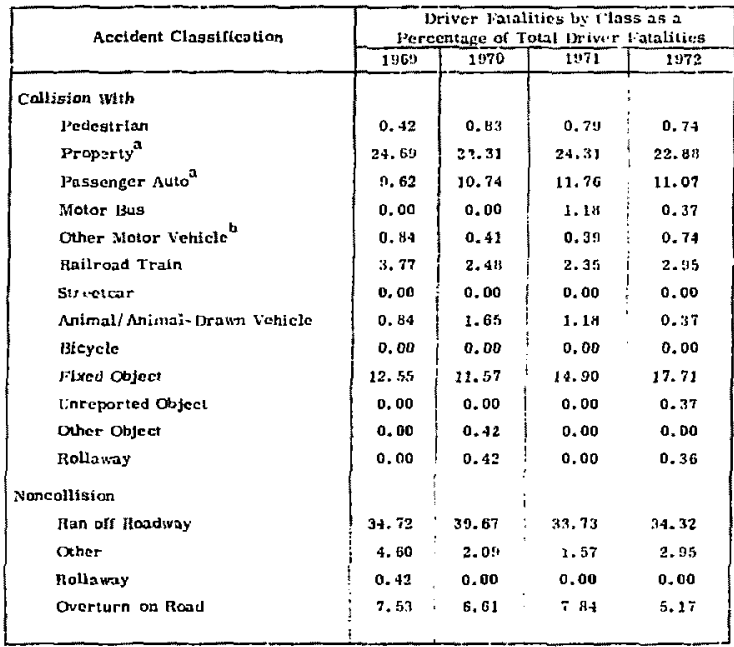

a Property refers to medium anil larpe trucks; light trucks stich is picktirs, pancls. and vans are classified as possergetr autos.

botorcycles are the majority vchicle in this category. 
TABLE A־DI

iumenary of Deiver Fatality Accident Rados for Moving Voticle Acodchts, 1068-1072 BMCS Reports

\begin{tabular}{|c|c|c|c|c|}
\hline \multirow[t]{2}{*}{ Accident Classtitication: } & \multicolumn{4}{|c|}{$\frac{\text { Defver Fatallueg aga Percentage of Total Driver fatalities }}{\text { Percentage of Total hovfing Vehicle Accidents iteposted }}$} \\
\hline & 1960 & 1070 & 2371 & 1022 \\
\hline \multicolumn{5}{|l|}{ Collision with } \\
\hline Pedestrian & 0.42 & 0.09 & 0.93 & 0.93 \\
\hline Property & 3.58 & 1.47 & 1.53 & 3.43 \\
\hline Pagsenger Auto & D. 10 & 0.22 & 0.24 & 0.23 \\
\hline Motor Bus & o. & o. & 2.68 & 0.64 \\
\hline Other Motor Yehtele & 1.78 & 0,72 & 0.65 & 1.30 \\
\hline Rallroad Train & 6.39 & 3.76 & 4.52 & 5.36 \\
\hline Streetcar & 0. & 0. & 0. & 0. \\
\hline AnLmal/Anlmal-Drawn Vehtcle & 1.05 & $\underline{2} 20$ & 1.49 & 0.54 \\
\hline Bleycle & 0. & o. & D. & a. \\
\hline Flxed Object & 0.80 & 0.83 & 1.02 & 1.111 \\
\hline Unreported Object & 0. & o. & 0. & 3.36 \\
\hline Other Object & 0. & 2.93 & 0. & o. \\
\hline Rollaway & : 0. & 0.32 & 0. & 0.36 \\
\hline \multicolumn{5}{|l|}{ Noncolltion } \\
\hline flan off Rozdway & 5.06 & 5.76 & 5.27 & 5. 30 \\
\hline Other & 0.76 & $0 .+3$ & 0.21 & n. 11 \\
\hline Rollaway & $14.00^{2}$ & 0. & 0. & 0. \\
\hline Overturn on Road & 2.84 & 2.26 & 2.76 & I. 30 \\
\hline
\end{tabular}

${ }^{a}$ This apparestly hitg number la the result of one driver falally and a small number of accident $B$. 
ThISLA A-II

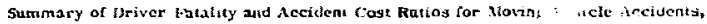
1060-1172 indes Reports

\begin{tabular}{|c|c|c|c|c|c|}
\hline Accident Clessirication & $\begin{array}{l}\text { Number of } \\
\text { Accidents }\end{array}$ & $\begin{array}{c}\text { Briver } \\
\text { vatulities }\end{array}$ & $\begin{array}{l}\text { 1xilar cos! } \\
\text { Thougand. }\end{array}$ & $\begin{array}{l}\text { rives Fatalits } \\
\text { Satio }\end{array}$ & $\left\{\begin{array}{c}\text { Accident } \\
\text { cost Ratio }\end{array}\right.$ \\
\hline Collision With & & & ; & & \\
\hline Pedegtrion & 1520. & $i$ & 223i 0 & 0,72 & $0.0 \mathrm{H}$ \\
\hline Property & $2 \times 101$ & 277 & H21.92.6 & 1.50 & $\ldots .+1 t^{2}$ \\
\hline Passenger Auto & $8726 u$. & $10 \xi$ & 106449.0 & 0.22 & 0.62 \\
\hline Motor Hus & $7 H 7$. & 4 & 1721.5 & $0 . \$ 0$ & 1.11 \\
\hline Orher Vehicle & 1049. & 6 & $17+43.7$ & 1.02 & 0.115 \\
\hline Mollraod Train & 1027. & 20 & 72013.1: & $5 . \mathrm{U}:$ & 3.60 \\
\hline Sirecetcar & ?. & 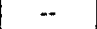 & 6. +1 & $\ldots$ & 0.36 \\
\hline Animal/Animal-1rons Vehicle & $12+i$ & 10 & 2603.1 & 1.32 & 1.01 \\
\hline Bieycle & $m 2$. & $-\cdots$ & 30.0 & 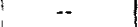 & $0.0 n$ \\
\hline Fixed Object & $25 ! 474$ & 144 & 41301.6 & D. $4 ! 1$ & 0.31 \\
\hline Inreported Cbject & 216. & 1 & $\mid x^{2}+4$ & $0,2: 2$ & 0.47 \\
\hline Other Object & 270. & 1 & 275.4 & $0.6 t$ & 0. $5: 1$ \\
\hline Rollaway & $20 \div 0$ & 3 & $25 \% \cdot 1.7$ & 0.17 & $0_{n} \in 1$ \\
\hline acol3ision & $i$ & & & 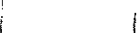 & \\
\hline Grerturn on lloav & 5065 & G:i & $27014 .:$ & $2.23 ! 4$ & 3.71 \\
\hline Ran off lload & 11676. & 3.54 & $60 x+3.3$ & 5. 36 & $\because 54$ \\
\hline Other & 12251 & .30 & $177: 10.6$ & 0.44 & 0.74 \\
\hline 1zollaway & 67. & 1 & 13.74 & 2.65 & 0. 71 \\
\hline 'IUTA. & $17007 \%$ & 1007 & $352+152,:$ & & \\
\hline Hision Accidents & $1+15: 03$. & 850 & $277=78.0$ & 0. G. & $0, i s-i$ \\
\hline neollision Accidents & $2: 1267$. & $+5 \%$ & $1052+6.4$ & ?. $7 .:$ & 1. 11.1 \\
\hline
\end{tabular}


TAIn.F: A

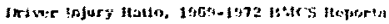

\begin{tabular}{|c|c|c|c|c|c|c|c|}
\hline \multirow{2}{*}{ Accident CDasiffcalloatb } & \multicolumn{5}{|c|}{ 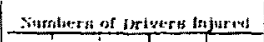 } & \multirow{2}{*}{$\begin{array}{l}\text { Sutniner at } \\
\text { scubrtenty }\end{array}$} & \multirow{2}{*}{$\begin{array}{c}\text { Extver ingury } \\
\text { usuo }\end{array}$} \\
\hline & J!nts. & 1) 1470 & $\mid 1+71$ & 2072 & Total & & \\
\hline \multicolumn{8}{|l|}{ collinion Witl } \\
\hline l'ethentrlan & 5 & 6 & 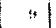 & is & $z s$ & $1 \div \geq 0$ & 0.1 .9 \\
\hline f'roperiy & tous: & $\{x+1 ;$ & 1215 & 1296 & $+6-2$ & 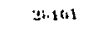 & 1.42 \\
\hline fustanter iोuts & $12: 30$ & bens & $\operatorname{lng}$ & $1,5.3$ & $\$ 7+m$ & navtix & 0.17 \\
\hline Mloter liug & 23 & 25 & 29 & 24 & 107 & 7117 & 1.17 \\
\hline Onher tehicle & $2 \%$ & $1 \tau$ & 21 & 11 & $n 1$ & $50.8=$ & 0.67 \\
\hline Hailgeste Trobl & f: & 67 & Cn) & 77 & 251 & 5027 & 2.75 \\
\hline Strevetciar & 1 & 0 & 0 & 0 & 1 & $\because$ & D. $\{$ Af \\
\hline 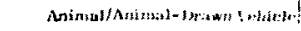 & 27 & 37 & +17 & $3 \pi$ & $1+2$ & $1.1: 1$ & 0.91 \\
\hline I3icycls: & 0 & 0 & 1 & 1 & 2 & $1: 2$ & $0.0 ! t$ \\
\hline Fixed (Ptsject & $47 e_{3}$ & $4 ; 7$ & 517 & $5+413$ & $19 M 77$ & $251,3.1$ & 0.66 \\
\hline Unroported olyeet & 16 & 11 & 7 & $H$ & 12 & 316 & L.G: \\
\hline Other Dturect & 10 & $: \mathbf{i}$ & ats & 27 & 50 & 270 & 2.147 \\
\hline Rollaway & $\vdots \mathbf{1 7}$ & $\vdots \boldsymbol{x}$ & II & 18 & 50 & $20 \leq 6$ & 0.21 \\
\hline \multicolumn{8}{|l|}{ Noncolltston } \\
\hline Overiurn on lioad & 15: & 550 & 573 & $66 !+1$ & 2200 & 5005 & $3+50$ \\
\hline Aan off lloall & 1170 & 1157 & 1204 & 150 & $4 \$ 10$ & 11136 & 3.57 \\
\hline Ouler & 360 & 300 & 330 & 350 & 1367 & 1325 & 0.00 \\
\hline Rollaway & 0 & 0 & 1 & 0 & $\mathbf{t}$ & 67 & 0.13 \\
\hline
\end{tabular}


1.1611. A :1

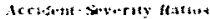

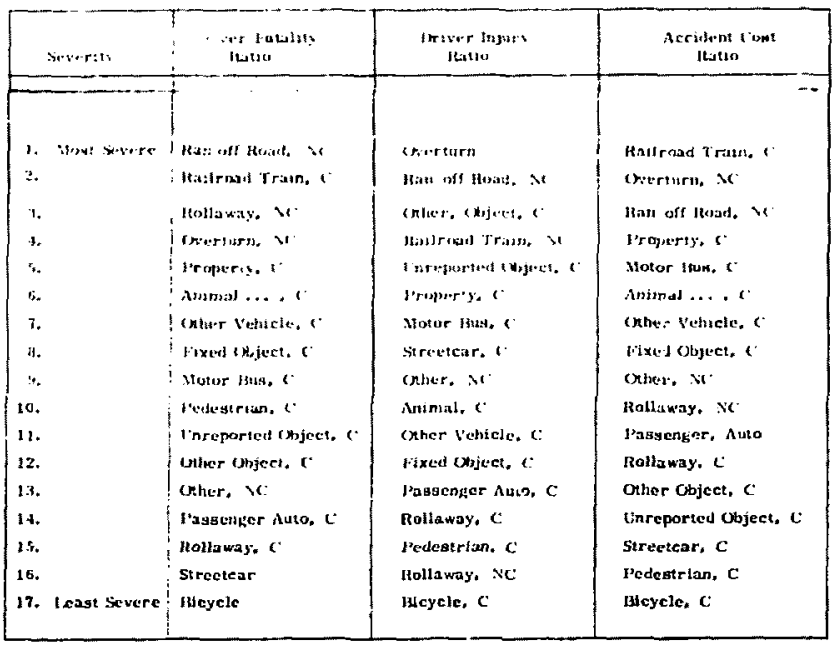

Yote: C-Collision; NC - Nanechlision 
TAdst.t: A- - Tt

Accidant-Severity listion for flevised Aceldent calegories

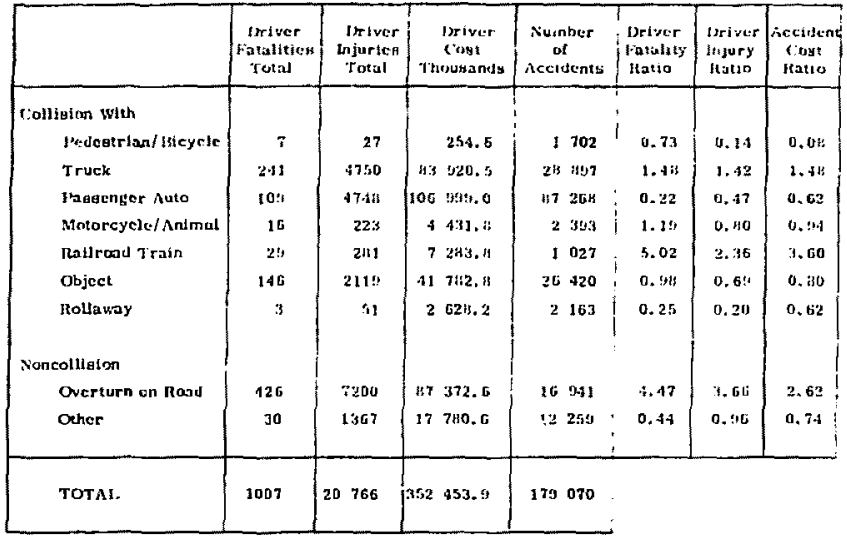

TABLE $\Lambda=V I I I$

Revised Acefdent-Severity Ratíngs

\begin{tabular}{|c|c|c|c|}
\hline Severity & $\begin{array}{c}\text { Driver frolaltity } \\
\text { Ratio }\end{array}$ & $\begin{array}{l}\text { Drlver Injury } \\
\text { Ratio }\end{array}$ & $\begin{array}{l}\text { Recident Cost } \\
\text { Ratto }\end{array}$ \\
\hline $\begin{array}{l}\text { 1. Moat Scuere } \\
\text { 2. } \\
\text { 3. } \\
\text { 4. } \\
\text { 5. } \\
\text { 6. } \\
\text { 7. } \\
\text { 8. } \\
\text { 0. Legst Severe }\end{array}$ & 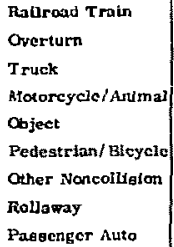 & $\begin{array}{l}\text { Oyerturn } \\
\text { leallrond Train } \\
\text { Truck } \\
\text { Other Noncolision } \\
\text { Motorcycle/Anlmal } \\
\text { Object } \\
\text { Passenger Auto } \\
\text { Roliaway } \\
\text { Pedegtrian/Bicycle }\end{array}$ & $\begin{array}{l}\text { Hallroad Train } \\
\text { Overturn } \\
\text { Truck } \\
\text { Motorcyele/Arimal } \\
\text { Object } \\
\text { Other Noncollision } \\
\text { Passenger Auto } \\
\text { Rollaway } \\
\text { Pedestrton/Gicycle }\end{array}$ \\
\hline
\end{tabular}


APPENDIX B

MOTOR-CARRIER ACCIDENT DISTRIBUTIONS

B-1, 2 


\section{Appendix 8 \\ MOTOR-CARRIER ACCIDENT DISTRIBUTIONS}

\section{Introductio :}

The ansly sis of abnormal hithway environments by Moute Carlo tectniqurs reyuires a knowledge of the trequency of eccurrenet of each of the events. This appendix addresges the question of frequency of occurrence of the different types of commercial truck accidents.

\section{Truck/Truck and Truck/Auto Accident Distribution}

In an analysis of the type being attempted, it is necessary to classify accident situtions and

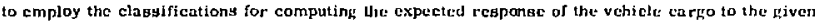
situation. The colligion accident situations lave been clagsificd a collows:

1. Ileat-On. Vehicle centerlines coincident and vehieles traveling in opposite directions.

2. Rear-trici. Vehicle centerlines coincident and vehicleg traveling in the same direction.

3. Side-on. Vehicle traveling poths that form a right angle and intersect at the centrotd of the vehicle that to struck.

It becomes is matter of judgment to distribute the known acelurnt population ${ }^{2-6}$ into the degignaled categorieg. It ig desired to maintain a degrec of conservat and to maintain a measure of this conservatigm.

Bureau of Motor Carrler Safety (BMCS) reporLs, 1069 through 1972, werc used to establitgh three of the four distributions considered and to evaluate the conservatism aseociated with each of the four dlatributions.

1. Propnrtional Aseignment of Cnkowns. Those accidents that can be definitely identified as belonging to one of the flve collision categories

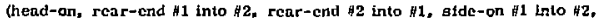
and side-on Into $\# 1)^{* ;}$ are assigned to that eategory. Collisions of unknown categories are assigned to the five eategories in the same proportion as the accidents of known categorics.

"In the BMCS reports vehicle $t 1$ alwayg refers to the reporting vehicle; in this study ychicle 11 is assuned to be the vahlele trangporthing the cargo. 
2. Equal Aasignment of Unknowns. The game procedure as above la uaed for calligions of known categorleg. The collielong of unknown categorigs are divided into five equal groupg and assigned to the tive known categories.

3. Equal Likelihood. Al tive known categories are congidorea equally Likely to occur. This distribution is not based on BMCS reparts.

4. SLA-74-0001 Diatribution - The diatribution used in Reforence 1. This dictribution is aloo based on DrtCs reports.

Inasmuch as a conscrvative approach lo used in this study, angle colliglons are disregarded even though most of the actual collision accideinte are of this type. The reason is that a data ect sufficient for eatabliahing angleg and their associated frequencies could not be found.

The BAICS reports, which form a bagis for the firat two diatributions, contain information on the number of reporting-vehicle drlvere kllled or injured ' $\mathrm{n}$ a given type of collision. For cxample. in the 1060-1072 period, 20 drivers of roporting vehiclea wore kdled in 435 head-on truck/truck collisions. Simllar statiaticg are available for fitalitice and injuries in each of the Lve colliaion eategories noter. ThL information was omployed to compute driver fatalities per accident and drlyer infurleg per accident lor truck/truck and truck/auto collision, shown in Taile $\mathrm{B}+\mathrm{F}$. The tour aceident distributions are ahown in Tabic $\mathrm{B}$-11.

TABLE B-I

1960-1872 BMCS Accident Data - Injury and Fatelity Rateg

\begin{tabular}{|c|c|c|c|c|c|c|}
\hline $\begin{array}{l}\text { Type } \\
\text { of } \\
\text { Aceldent }\end{array}$ & $\begin{array}{c}\text { Total } \\
\text { Driver } \\
\text { Fatalltiog }\end{array}$ & $\begin{array}{l}\text { Totol } \\
\text { Dtiver } \\
\text { Injuries }\end{array}$ & $\begin{array}{c}\text { Total } \\
\text { Sumber of } \\
\text { Accidents }\end{array}$ & $\begin{array}{l}\text { Driver } \\
\text { Fatalltieg } \\
\text { per Aceldent }\end{array}$ & $\begin{array}{l}\text { Driver } \\
\text { Injuries per } \\
\text { Accldent }\end{array}$ & $\left\{\begin{array}{c}\text { Fraction ol } \\
\text { Aceidente } \\
\text { Considered }\end{array}\right.$ \\
\hline \multicolumn{7}{|l|}{ Truck } \\
\hline Head-On & 29 & 162 & 435 & 0. 0867 & 0.3724 & 0.0405 \\
\hline Rear-Bnd \#1 into & 77 & 1130 & 4573 & 0.0188 & 0.2471 & 0.4255 \\
\hline Rear-End 12 into 12 & 7 & 1103 & 4303 & 0.0016 & 0.2563 & 0. $\$ 004$ \\
\hline Intersectlon 11 into 12 & 2 & 77 & 459 & 0. D044 & 0.1678 & 0.0427 \\
\hline Intersection 12 Into & $\mathbf{5}$ & 184 & 978 & 0.0051 & 0.1881 & 0.0910 \\
\hline Auto $\quad+\cdots$ & & $\cdot \cdot-\cdots$ & ... & (n- & - & \\
\hline Ifead-On & 13 & 469 & 1803 & 0.0072 & 0.2712 & 0.0539 \\
\hline Rear-Dad ol into 12 & 12 & 396 & 12303 & 0.0010 & $0.032 \mathrm{D}$ & 0.3595 \\
\hline Fear-End Hz Lnto & $\mathbf{z}$ & 495 & 10159 & 0.0002 & 0.0485 & 0.3032 \\
\hline Intergection 11 Into $\# 2$ & 3 & 170 & 2490 & 0,0012 & 0,0883 & 0.0742 \\
\hline Interaection 2 Into 11 & $\mathbf{g}$ & 611 & 6684 & 0.0013 & 0. 0914 & 0.1093 \\
\hline
\end{tabular}

Tokal reported truck/truck collifions, $1969-1972=28$ (Includes streetcara and motor bues)

Total reported truck/auto colletong, 1859+1972 $=87679$ 


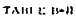

Mechilent lagertbutlon rictars

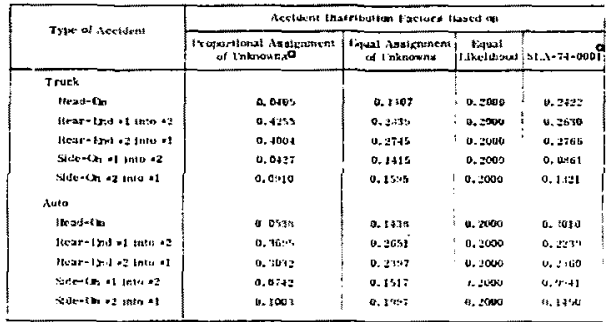

- Tlye diserepancy in theat valugy is duc to an orrongous inlerpretation in SL $\Lambda$-74-0001 of the BMICS side-on colligton entegory.

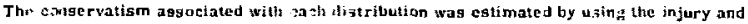
fatality informatinn, the asgumed colligion dis: ribulion, and the total number of ascidente to predict the number of driver injuries and fotalities knit would lave resulted from the agsa ned digl ribution. The predicted triver injuries and batalieg were divited by the number of injuries and fatalitieg reported by bilcs. This ralio is considered 3 measure of the conservatism of the agsumed distribution. Pred.cted injuries and fatalities" recorded injuries and fatalities, and the ratus are shown in Tabie 13.IIt. For the purpose of this gtudy. the distribution using proportional assignment of unknowng was chosen as beinf moyt represeniative of actual colligion environment.

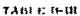

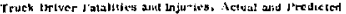

\begin{tabular}{|c|c|c|c|c|c|c|}
\hline ThPr at Leastibution & 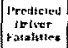 & 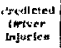 & 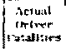 & \begin{tabular}{|} 
iclual \\
tetter \\
teftice
\end{tabular} & 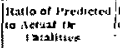 & 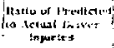 \\
\hline Iruez & & & & & & $\hat{\xi}$ \\
\hline 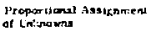 & 324 & $y \geq 11$ & $2+1$ & 1750 & 1.7 & 1.10 \\
\hline $\begin{array}{l}\text { Equal Anutemintert of } \\
\text { Linknowns }\end{array}$ & 46.1 & 7127 & $3+1$ & 1730 & t. +2 & $1, x$ \\
\hline Haldol tukcllhool & 547 & $\boldsymbol{x} \boldsymbol{n}$ & $2+1$ & $4 \pi ! 0$ & 2.27 & 1.50 \\
\hline S1_A-74×0001 & Gis & 7 bos & $3+1$ & 1550 & 2.6 .5 & b: (i) \\
\hline tulo & & & & & & . \\
\hline 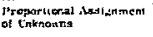 & 102 & $\$ 620$ & $10^{24}$ & 15:1 & 0. 91 & 1. 1 \\
\hline 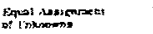 & 136 & 365 & $50^{5}$ & 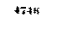 & 1. 63 & 1. : :it \\
\hline Eqpal intellnoon & 100 & $B \pm 1 \geq B$ & 109 & $12+6$ & $1.7+$ & 1. \\
\hline SIAA=Tqumal & 230 & $1 a+65$ & 105 & 17411 & 2.1: & 2.00 \\
\hline
\end{tabular}




\section{Truck/Train Accident Distribution}

There are two cagng that must be congidered in the truek/train colligion or Ident:

1. Truek is struck by the train.

2. Truck rung into side of the train.

Table B-IV contains information for the period 1069 through i972 by type of collision. $7-10$ It can be obscrved that is $\mathbf{3 5}$ percent of the accidents the truck fo etruck by the train. In the remaining 25 pereent, the truek rung Into the side of the traln. This fo the Jistribution used in the analyais.

TABLE HMIY

Truek/Trath Accident Statisties, 1969-1972a

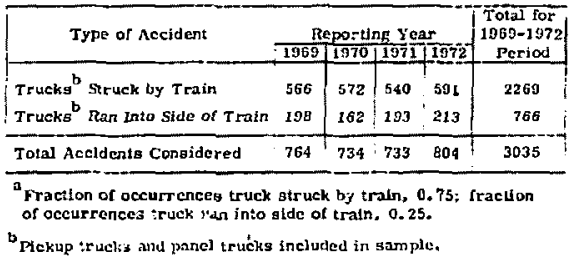

\section{Distribution of All Truck Accidents for Analysis}

The bagic dath get can be broken down into two general categorfes, Colligjon Accldents and NancolUsion Accidents. Collision accidents Involve a primary impact with another vehicle, a pedestrjan, a bicyclist, a train, an antmal, or an object otber than the road and roadgide ierrain. Moncolugion acsidente involve fire, running off the rosd, overturning, and other auch accidents.

The noncolligion aceidents may include impacts with roadside ditches, bankg, the rondway. and other roadgide terrain features. Table B-V containg the basic accident distribution obtained from the BMCS data aet, which is uged in this stuty. 
TABLE B-V

Distribuion of Aecidents by BMCS Categories, 1969-1972

\begin{tabular}{|c|c|c|}
\hline Accident Classillcation & ! Number of Accidents & "Fraction of Totai. \\
\hline \multicolumn{3}{|l|}{ Collisirn With } \\
\hline Pedestrian & 1520 & 0.0085 \\
\hline Property & 28101 & 0.1569 \\
\hline Passenger Auto & 87268 & 0,4873 \\
\hline Motor Bug & 787 & 0.0044 \\
\hline Other Vehicle & 1049 & 0.0059 \\
\hline Rallroad Train & 1027 & 0.0057 \\
\hline Slreetcar & 0 & 0.0001 \\
\hline Animal/Animal-Drawn Vehicle & 1344 & 0.0075 \\
\hline Bicycle & 182 & 0.0010 \\
\hline Fixed Object & 25934 & 0.1440 \\
\hline Unreported Object & 216 & 0.0012 \\
\hline Other Object & 270 & 0.0015 \\
\hline \multirow[t]{2}{*}{ Rollaway } & 2096 & 0.0127 \\
\hline & $\vdots$ & $\overline{0.8365}$ \\
\hline Noncolligion & $i$ & \\
\hline Overturn on Road & 5065 & 0.0283 \\
\hline Ran orf Road & 11876 & 0.0563 \\
\hline Other & 12259 & 0.0685 \\
\hline \multirow[t]{2}{*}{ Rollawray } & 67 & 0.0004 \\
\hline & & $\overline{0.1635}$ \\
\hline TOTA]. & 170070 & 1.0000 \\
\hline
\end{tabular}

The basic aceident distribution was revised as followe for use in the analybis:

1. It is assumed that lasg of control of the vehicle when the driver is taklng evasive action causes the most damage in pedcstrian, other rehicle (motorcycle), anima/animal-drawn vonicle, and bicycle accidents. For the purpose of this study, the runsing-atr-the-rosdf overtum type of accident best describes thege colligion accidents,

2. The term "property" ceferg to carrlers of property (commercial Lrucks). Thig category was comblned utth the categories Motor Buses and Streetcara to form a single naw callision chtegory, Trucks. 
3. Fixed Objects, Unreported Objects, end Other Objecte were combined into a bingle catagory; Objecte.

4. Colliaton Foliawa; and Noecollision Rollaway were comblned into a ofigle category, Rollaway.

5. A new category, Overturn/Ran Of Road. was eatablfobed to thelude both collision and noncolyelon accidenta where the primary cargo damage was due to overturnirg or running off the road.

Table B-Vl containg a Lating of the BMCS accldent data in the reviged categorieg.

TABLE B-VI

Distribution of BatcS Data by Revised Categarles

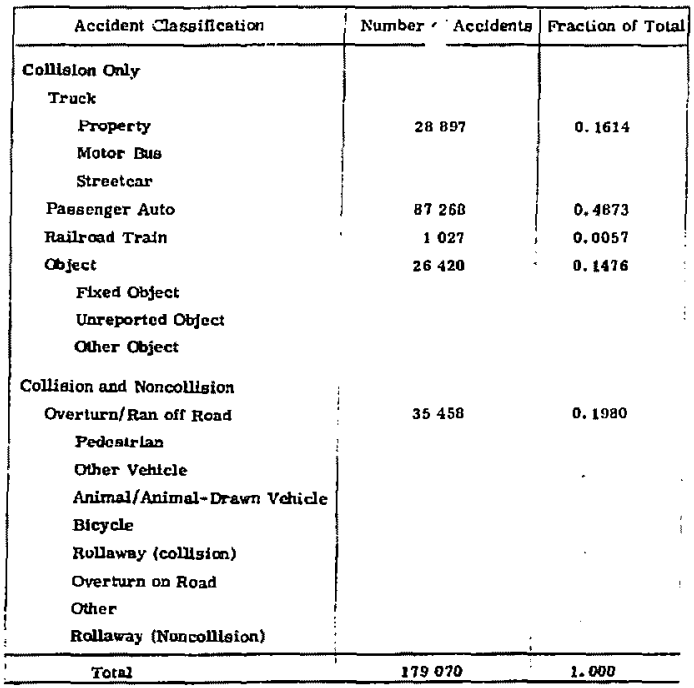


It can be observed that about 20 percent of the accidents tan in the new Overurn/Ran off Hoad category. It ia agaumed that this category can be conservatively represented by overturning and running-off-the-road accidents, except for those accidente in which the fire effects are a majo. cargo damage mechaniam.

The collibion-orly accidente are listed in Table B-VIl, along with the distributions selected for each category. It can be seen from this table that the collision aceident with the loweat expectation is a truck runing into the aide of a traln. The colliaion accident with the greateat expectation of occurrencn is a truck runging into the rear of an auto. It should be remembered that these are derlved distributions and not actual distributiong. The dlatributions are such that the number of truck drtver fatalites and infurtes sulfered in actual aceidents is conservalivcly approstmated by the aerived distributions.

TABLE B-III

Distribution of Hevised Categorfus by Type of Vehicic, Collision-Only Accjdents

\begin{tabular}{|c|c|c|c|c|}
\hline & $\begin{array}{l}\text { Fraction of Collision- } \\
\text { Only Accidents }\end{array}$ & & $\begin{array}{l}\text { Distribution } \\
\text { Factor }\end{array}$ & $\begin{array}{l}\text { Distribution for } \\
\text { Analysís }\end{array}$ \\
\hline Truck & 0,2012 & & & \\
\hline Heed-on & & i & 0.0405 & 0.0081 \\
\hline End-cn 1 into $\$ 2$ & & 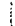 & 0.4255 & 0.0856 \\
\hline End-on 22 into is & & ; & 0.4004 & D. 0806 \\
\hline Side-on $\| 1$ into $\$ 2$ & & 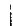 & 0.0427 & 0.0086 \\
\hline SIde-on $k 2$ into $\# 1$ & & $i$ & 0.0910 & 0.0183 \\
\hline Auto & 0.6076 & & & \\
\hline Heed-on & & & 0.0538 & 0.0327 \\
\hline End-an $\| 1$ into $\$ 2$ & & & 0.3695 & 0.2245 \\
\hline End-on the into $\$ 1$ & & . & 0.3032 & 0.1842 \\
\hline Side- on 11 into $\$ 2$ & & & 0.0742 & 0.0451 \\
\hline Side-on 82 into $\$ 1$ & & & 3,1903 & 0.1211 \\
\hline Rallroad Train & 0.0072 & & & \\
\hline Struck by train & & & 0,7500 & 0.0054 \\
\hline Ran into train & 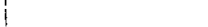 & & 0.7500 & 0.0018 \\
\hline Object & 0.1840 & 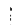 & $1.00=0$ & 3. 1840 \\
\hline
\end{tabular}


The distributon ghown in Table B-VIt is agoln presonted in Table B-Vnt, which comtains a reorganization at the data by effect on truck. Only three truck motione are permitled:

1. The truck lo decelersted along its une of travel; t. e.. the vehicle is atow of ta gtopped by ine collision.

2. The truck is accelerated alung the lina of travel: f. e., the vehtcle speed ts increaged by the rollision.

3. The truck is accelerated perpendicular to the line of travel; $1 . e$. the vehicle if moved aideways by the collision.

TABLE BNVID

Collision Aceident Distributian by Drection of Accelernuton Vector on Shipment Truck

\begin{tabular}{|c|c|c|}
\hline $\begin{array}{l}\text { Direction ef Accleration } \\
\text { Yector on Package }\end{array}$ & $\begin{array}{c}\text { Dintribution } \\
\text { Fectors }\end{array}$ & $\begin{array}{l}\text { Normallzed Sets of } \\
\text { Dietribution Eactore }\end{array}$ \\
\hline $\begin{array}{l}\text { Truck Decelerated } \\
\text { Along Ite Axis }\end{array}$ & $\vdots$ & \\
\hline Head=on, truck & 0.0081 & 0.0197 \\
\hline End-on $\sharp 1$ into 92 , truck & 0.0856 & 0.1450 \\
\hline Side-on $\| 1$ into $\# 2$, truck & 0.0086 & 0.0146 \\
\hline Herd-on, auto & 0.0322 & 0.0554 \\
\hline Erd-on 11 into $\mathrm{N2}$, auto & 0. 2245 & 0.3803 \\
\hline Side-an $\| 1$ sito 12 , auto & 0.0451 & 0.0764 \\
\hline Ram into train & 0.0018 & D. 0030 \\
\hline \multirow[t]{2}{*}{ Object } & 0.1840 & 0.3116 \\
\hline & $\overline{0.5904}$ & $\overline{1.0000}$ \\
\hline $\begin{array}{l}\text { Truck Accelcrated } \\
\text { Along Ito Axdg }\end{array}$ & & 1 \\
\hline End-on of into 81, truck & 0.0806 & D. 3044 \\
\hline \multirow[t]{2}{*}{ End-on H2 into $\mathrm{N1}$, auto } & 0.1892 & 0.6058 \\
\hline & $\overline{0.2648}$ & $\overline{1.0000}$ \\
\hline \multicolumn{3}{|l|}{$\begin{array}{l}\text { Truek Accelerated } \\
\text { Perpendicular to its Axda }\end{array}$} \\
\hline Stde-on ol into 1 , truek & 0.0193 & 0.1254 \\
\hline Side-on 2 ineo $l_{3}$ auto & 0.1211 & 0.8363 \\
\hline \multirow[t]{2}{*}{ Struck by train } & 0.0054 & 0.0373 \\
\hline & $\overline{0.1448}$ & $\overline{1 . \overline{1000}}$ \\
\hline
\end{tabular}


Theae three distributlons will be used ta compute the maximum volocits change of the vehiste mu cargo and the asgociated maximum energy change resulting trom a collistion scctident. If the cargo tiedown otrength is legs than that requifed to maintain the sargo on the vehicle, the tisdowns will gll and release the eargo. In this ctate the cargo velocity change will be less than the predicted maximun. 
APPENDIX C

MOTOR YEHICLE AND TRAIN SPEED DISTRIBUTION'S FOR MOTDR-CARRIER ACCIOENTS 


\section{Appendix C \\ MOTOR VEHICLE AND TRAIN SPEED DISTRIBUTIONS FOR MOTOR-CARRIER ACCIDENTS}

\section{Motor Vehicle Speed Distributions}

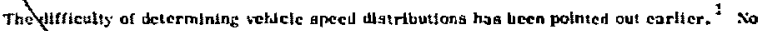

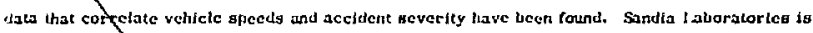
currently engatset in a jrogrim to outaln, it the state level, thta that whll link accident upeed and

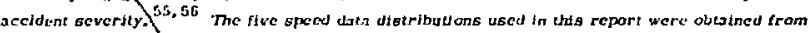
tue rollowtng sources:

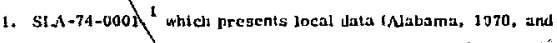
Texas. 19GJ) far spceds at which accidents occurred on rural highways.

2. Referenes 60, which preacnts local aluta (Texas 1J60) ror passenger-autamaceident speed distributiong and for truekaceldent distributions. These dala cover both urtan and rurit highwaye.

3. References 7-10 (Fru data), which present datn for the specds of vehleigs involved in rall road-highway grade-crosging aceidents.

4. Reference 61, which presents data on the actun speed of vehicles recorded on tangent sections of main reral highways during offpeak hours. This onmpic is frec-lowing heghwoy traftic and does not reflect any accident tru lyvements. A review of the RMCS date for 1969-1972 alloxs the following speed infarences:

a. Approximately 10 percent or the accidents listed rellect very low speed for anc or both vehicles. These include backing. gtoppedmin-fraffic, and rollaway nccidento.

b. Approimately 30 percent of the aceldents are lop- to moderate-speed accident $\mathrm{B}$. These include turning, intergection, and skldding accidente (inclement weacher conditions ascaned for the last cage).

c. The balence, approximately 60 percent of the accidents, are moderate- to hlgh-speed aceidente. Theve include head-on, rear-end, pagsing, and gideswipe accidento.

tRural here meang all highways outaide of city limits and excludes iniracity accidents. 


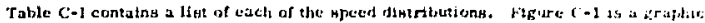

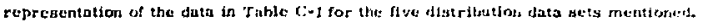

\section{TAill:}

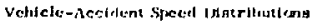

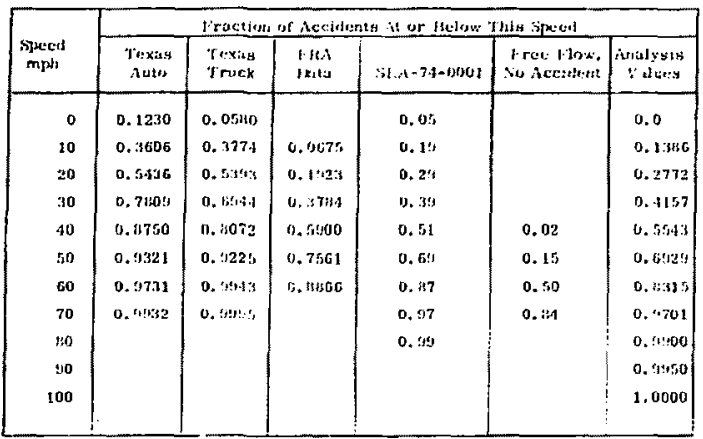

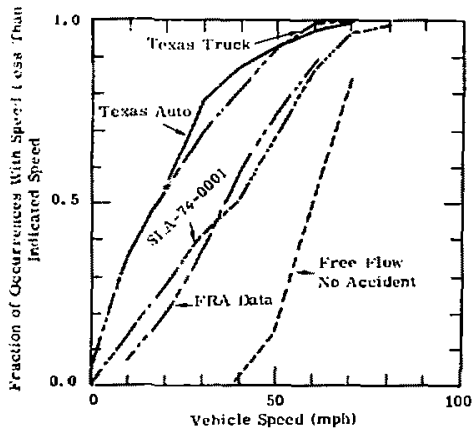

Figure C-1. Vohicle-accident speed distribution. 


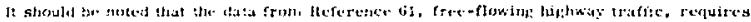

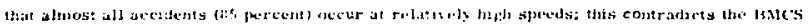

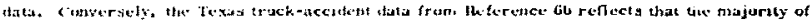

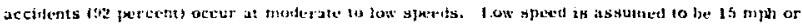

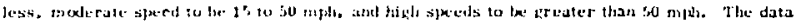

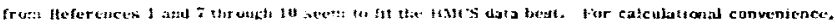

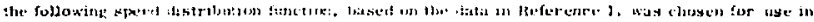
the an;ilysity.

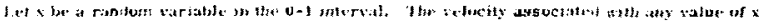
all this be canc: by

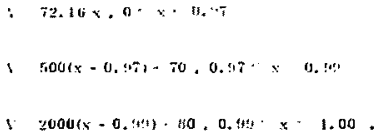

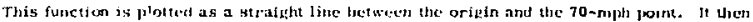

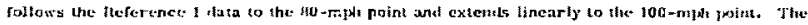

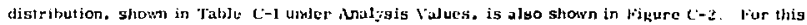
distribution. 21 percent of the velocities will ise at or below $15 \mathrm{mph}$. 69 percent at ar bejew $50 \mathrm{mph}$. and 31 percent above $50 \mathrm{mplh}$, The distribution appears to offer a reasonable fit to the knonsin condîtions.

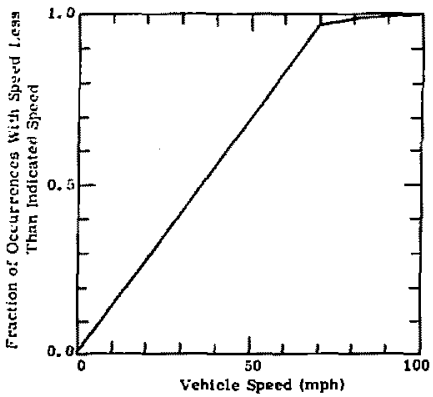

Figure C-2. Vehicle-accident specd distribution used in the sualysis. 


\section{Train Speed Distribution}

The Federal Ratirad Administration (FRN) data for the yeare 1950 through $1972^{7-10}$ form the baste for this wetribution. Table C-II contalns a year-by-year breakdown of irain opeeds ar cases where the erain atruck the yehicle. Figuro $\mathrm{C-J}$ is a plot of these data. The irain epced diutribution used in the grarte-croasing accilent anajysis is determined by the following relationghips:

$$
\begin{aligned}
& V=\frac{10}{0 . \overline{0} 009} \times, 0 \leq x<0.0400 \\
& V=\frac{40}{0.7265}(x-0.0809)+10,0,0500=x-0,1416 \\
& V=\frac{10}{0.1067}\{x-0.8\{64\}+50,0.11104 \leq x<0.0231 \\
& \left.V=\frac{10}{0.0401}(x-0.9235)+00,0.523\right) \div x<0.0722 \\
& V=\frac{10}{0.0240}(x-0.0722)+70.0 .0722 \leq x<0.9062 \\
& v \cdot \frac{10}{0.0026}(x-0.9962)+00,0.9962 \leq x<0.9986 \\
& y=\frac{10}{0.0012}(x-0.0988)+90,0.0988 \leq x \leq 1.00 .
\end{aligned}
$$

\begin{tabular}{|c|c|c|c|c|c|c|}
\hline \multirow{3}{*}{$\begin{array}{l}\text { Speed of } \\
\text { Troin } \\
\text { (mph) }\end{array}$} & \multicolumn{5}{|c|}{ Number of Accidents } & \multirow{3}{*}{$\begin{array}{l}\text { Pracilon } \\
\text { of } \\
\text { Tofal }\end{array}$} \\
\hline & \multicolumn{5}{|c|}{ Vefucte siruck by Train } & \\
\hline & 1869 & 1970 & 197נ & 1972 & Tolal & \\
\hline $\mid=1$ & 253 & 179 & 202 & In: & 326 & 0. O40y \\
\hline $10-19$ & 348 & 362 & 354 & 342 & 1406 & 0.1530 \\
\hline $20-29$ & 454 & A52 & 463 & งเหล & 1057 & 0.2032 \\
\hline $30-30$ & 455 & 44 & 463 & 467 & 1820 & 0.1900 \\
\hline $40-49$ & 972 & 310 & 401 & 43: & 1574 & 0.1713 \\
\hline $50-50$ & 272 & 252 & 237 & 220 & $\mathrm{ge} 1$ & 0.1067 \\
\hline $60-69$ & 140 & 311 & 109 & 01 & 451 & 0.0491 \\
\hline $70-79$ & 82 & 77 & 32 & 30 & 221 & 0.0240 \\
\hline $40-80$ & 7 & 10 & $\mathbf{s}$ & 2 & 24 & 0.0026 \\
\hline po \& ovar & $\mathbf{6}$ & 2 & 3 & - & 11 & 0.0012 \\
\hline TOTAL & 2389 & 2200 & 2260 & 2263 & 3100 & 1.0000 \\
\hline
\end{tabular}

where $x$ is a randorn variable whose value is between zero and one.

\section{TABH.E C-I}

1069+1972 PRA Rall-1ighway Aecident Data, Giving Sperd of Train a: Time of Aceident 


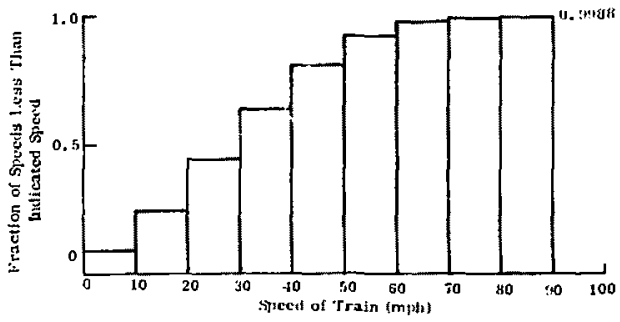

Figure C-3. Train/vehicle grade-crossing aceldent data, giving speed of train at t Ime of accident lirom 1969-1972 FiA Rnil-Highway Aceldent Dois - 9190 accidents).

Table C-10 is a comparison of the FRA daw and the continuous-specd distribution assumed in this analysis. Figure $C-4$ is a plot of the train speed distrlbution function. All velocltiea are in milee per hour.

$\therefore \quad$ TABLE C-HI

Grade-Crossing Accident Data, Giving Speed of Tratn at Thme of Accident

\begin{tabular}{|c|c|c|}
\hline $\begin{array}{c}\text { Speed of Traln } \\
\text { (mph) }\end{array}$ & $\begin{array}{c}\text { Fracuon of Acelochts } \\
\text { BeJow thie Speed } \\
\text { (FRA data) }\end{array}$ & $\begin{array}{l}\text { Fracton of Aceidests } \\
\text { Ielow this Speed } \\
\text { (assumed distribution) }\end{array}$ \\
\hline 0 & 0. & 0. \\
\hline 10 & 0.0859 & 0.0899 \\
\hline 20 & 0.2420 & 0.2715 \\
\hline 30 & 0.4461 & 0.4532 \\
\hline 40 & 0.6451 & 0.6398 \\
\hline 50 & 0.8164 & 0.8164 \\
\hline 60 & 0.9231 & 0.8231 \\
\hline 70 & 0.9722 & 0.9722 \\
\hline 80 & 0.9952 & 0.9962 \\
\hline 90 & $0.998 \mathrm{~B}$ & 0.9988 \\
\hline 100 & $-\infty$ & 1.0000 \\
\hline
\end{tabular}




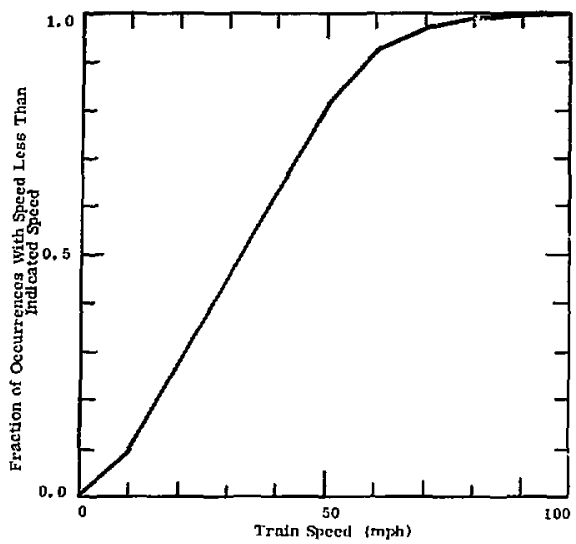

Figure C-4. Railroad train gpeed distribution used in gradecrossing analyeis. 
APPENDIX D

WEIGHT DISTRIBUTIONS FOR

MOTOR CARRIERS INVOLVED IN ACCIDENTS 


\title{
Appendix D \\ WEIGHT DISIRIBUTIONS FOR \\ MOTOR CARRIERS INVOLVED IN ACCIDENTS
}

\author{
Motor Vehicle Weight Distribution
}

Introduction

The weight of the vehtcle is one of the principal variables in this andysis. Although it might be passible to determine the welght digtribution for all passenber autos and uncks fa the United States, the work frvolved would outwelgh any advantages that might be be gained in aceuracy. One posglbie problem, however, involves identlficatt $\pi$ of pasgonger sutog and trucks as reported in the BMCS accident etatistica. The dntn for the year 1972 wll be considered to point out the reagon for concem in this ares. The informattas displayed in tabular form in Tables $\Gamma_{-1}$ and D-II was obtained from References 5 and 61 .

TABI,E D-I

Motor Vehicle Stallstics, 1972

\begin{tabular}{|c|c|c|c|c|}
\hline & $\begin{array}{c}\text { Number of } \\
\text { Vohicleg } \\
\left(\times 10^{-3}\right)\end{array}$ & $\begin{array}{l}\text { vehicle Auleage } \\
\left(\times 10^{-9}\right)\end{array}$ & $\begin{array}{l}\text { Percent of } \\
\text { Total Vehicles }\end{array}$ & $\begin{array}{l}\text { Percent of } \\
\text { Total Mileage }\end{array}$ \\
\hline Pagsenger Auto & Q6 850 & $2003,5^{3}$ & 70.20 & 80.08 \\
\hline Bus & I 901 & 5.1 & 1.55 & 0.41 \\
\hline $\begin{array}{l}\text { Pickup/ Panel } \\
\text { Truck }\end{array}$ & 14462 & 155: 7 & 11.62 & 12.42 \\
\hline $\begin{array}{l}\text { Trucks foxcluding } \\
\text { plekup/panel } \\
\text { trucks) }\end{array}$ & 5283 & 8B. 8 & 4.32 & 7,09 \\
\hline Motorcycles & 3798 & & 3.11 & \\
\hline TOTAL & 122304 & 1253.1 & 100.0 & 100.0 \\
\hline
\end{tabular}

\footnotetext{
Includea matorcycles.
} 
TABLE D-II

Percent of Colliston Accidents by Type of Moter Vehicle 1972 BMiCS Report

\begin{tabular}{|c|c|c|}
\hline Type of Vehicle & $\begin{array}{l}\text { Total collieton } \\
\text { Accidents }\end{array}$ & $\begin{array}{l}\text { Percent of Total } \\
\text { Colligion Accidents }\end{array}$ \\
\hline $\begin{array}{l}\text { Passenger Autos, Jaxis, } \\
\text { Pickup Trucks, Pancl } \\
\text { Trucks } \\
\text { Trucks (excluding pickups } \\
\text { and panolg) } \\
\text { Motor Hug } \\
\text { Othet Motor Vehicles } \\
\text { (motorcycles) }\end{array}$ & $\begin{array}{r}25 \quad 235 \\
4393 \\
230\end{array}$ & $\begin{array}{l}\text { 73. DH } \\
24.57 \\
n . G T\end{array}$ \\
\hline TOTAL & 34109 & 09.09 \\
\hline
\end{tabular}

The MMCS category "Property" contalns only collisiang between two carriers of property (eammercial twekg). These truck/Luck collisiong are further delined by BMCS to exelude pickup trucks and panel trucks. ${ }^{62}$ IHckupe and pasels represent over 10 percent of total velicle regietrations and alniost 75 percent of truck registrations. Thus, the shift of these vahicles from the truck/truck colligion to the truckmpassenger auto collyion category ls significant. Trucks fexeluding plekupg and pancla) repregented 4.3 percent of the total registered motor vehicics and 7.1 percent of the total vehicle mlleage in 1972, but 24.6 percent of the jotor vehicle collision accidents reported to DAICS were truck/truck soldeions. The uMCS data contain a mote complete and detalled report of large-truck accidentg than any other data set known to the auchor. $A$ further dincussion of BMCS data dealing wth the 1969 report can be found In Reference 60 and in Appendix A. The method of analysis ueed Is such that a collision with a truck las defined by BMCS) will produce a more bevere envtronment than collision with a pickup or panel-type vehicle. The accident analygls wil then be coseervative if colligiong with trucks are overrepresented.

\section{Pageenger Autos: Plckup and Panel Truekg}

The gross vehicle woights for llfierent types of light vehicles vere obtained from Refermce 63. Curb weight of pagaenger cars generally ranged from 2800 to 5000 pounds, wh a few models outside this range. The maxdmum recommended load for these vehleles generally ranged from 600 to 1200 pounde. The 4000 - to 5000 maund curb welght appeare to be piredominant. For thite study it was assumed that the weight of passenger cars could be conservatively represented by the fanction

$$
w=3000 x+3400 \text { pounds },
$$


whe $\mathrm{x}$ is a random variable in the 0-1 intervs.

Fickup trucks present a problem gomewhat greater that do autos, atnce the optlong gelected by the buyer can aubstaminly affect the curb weight of the vehicle. Nlogt of the pickup trucks are one-half-ton vehleles with a baglc weight in the 5000 - to 6000-pound range. The weight of panel trucks was assumed to be the aame as that of pickups. The following function was used wo repregent welght of plekup and panel trucks;

$$
w=5000 x+5000 \text { pounds }
$$

where $x$ is a random veriable chosen th the $0-1$ intervat.

\section{Trucks fexcluding pickupg and pancls i}

The welght Hatribuiton for trueks was determined by use of registration informau on from Reference 61 and maximum logal weight information from Reference 64. This triormation is presented in Table $\mathrm{D}$-III. The welght dlateibution functian chosen to sepregent trucks is

$$
\begin{aligned}
& W=\frac{18000}{0.7310} x+10000 \cdot 0 \leq x<0.7310 \\
& W=\frac{48000}{0.2540}(x-0.7310)+28000,0.7310 \leq x<0.0950 \\
& W=\frac{24000}{0.0150}(x-0.0850)=76000,0.9850 \leq x \leq 1.0 .
\end{aligned}
$$

\begin{tabular}{|c|c|c|c|c|}
\hline $\begin{array}{l}\text { Type of Truck } \\
\text { (number of axles) }\end{array}$ & $\begin{array}{c}\text { Registrations } \\
\text { (1000s) }\end{array}$ & $\begin{array}{l}\text { Percent of Tatal } \\
\text { Registrationg }\end{array}$ & $\begin{array}{l}\text { Cumulative } \sigma_{0} \\
\text { of Tolal Rag. }\end{array}$ & $\begin{array}{l}\text { Maximum Legal } \\
\text { Woight }(1000 \mathrm{lb})\end{array}$ \\
\hline 2 -axle & 3862 & 73. 10 & 73.10 & +28 \\
\hline 3-axle & 652 & 12.34 & 65. 44 & 44 \\
\hline 4-axle & 273 & 5.17 & 90.61 & 60 \\
\hline 5-axle & 417 & 7.89 & 08.50 & 76 \\
\hline All others & 79 & 1. 50 & 100.00 & $100^{a}$ \\
\hline TOTALS & 5289 & 100.00 & & \\
\hline
\end{tabular}

where $x$ is a random variable chosen in the 0-1 interval.

TABLE D-III

Distribution and Welghts of illedium and teavy Trucks

Asenmed maxinum weight lor the etudy. 


\section{Train Weight Diștribution}

An earllet study. Refenence 65, cound thar the total weight of the train is not algnificart go long ag it is eubgintlally greater than tho welght of the contalner and transport truck. In thls study the train is abaigned a weight aufticlent to ensure that the pachage veloclty change approximates

1. The prenceldent iratn opeed for eages where the tratn strikos the truck.

2. The preaceddent truck speed far cases where the truck btrikes the iratn.

\section{Object Weight Oistribution}

Three Bxics object clagalications have been included In this distribution. The BMiCS classilicatians "F1xed Oojects," "Unreparted Objects, " and "Other Objectg" have been comblned to form a single new classification. "Stationary Offects." This category accounts for id percent

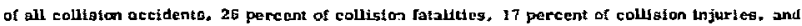
17 percent of collision doilar costs. Colliston with an object can range from hitting a algn post to colyding with a bridge pler or abutinent. It is the author'g opinion thet the degree of hazard associated wth object impacts is generally overemphasized. This bpe of collston ranks below Rajlraad Train, Truck, and Motorcycle/Animal collibions in severity and above [Pedestrian/ Bicycle, Passenger Auto, and Rollaway collistong (Appendix A).

The term "Bridge Abutment," rrequently found In object impact discusaions, is often misused or misunderstood. The bridge abutment serves to trangmit the load from the bridge superstructure to the foundatlon and also acts as a retaining wall to bold back the earth fill behind it. Consequently, the bridge superstructure is placed above the top of the abutment. The abutment generally docs not project above the bridge deck and hence is not the objectimpacted by a vehicle crossing the bridge.

It is posalble for a vehlele to collde with the abutment of a bridge (overpase) that is ovor the vehicle's roadway. In this cage, however, it is comman to place the breastwall of the abutment paraliel to the highway and the wingwalle of the abutment at an angle (not perpendicular) to the highway. Good degifen practice calls for getting the obutments back from the roadway to minimlze the hazard to vehicles. In general, it is very difficult for a vehicle to hit a bridge abutment in a right-angle for near-riyht-angle) Impact gltuation. Eridge plers, supports placed between abutmente, are quite a different matter. Phers take many forms, but are commosly seen as intermediate supports of interstate highway bridges. The principal differences between the piers and abutments, from a collision geverity fiewpoint, are that the plers are generally mach legs magsive than the abutments and the prers are not earth backed. 
The deacyiption of a fixed object was based an data abtrined from the a ate of Colorado. ${ }^{66}$ These data were Imited to vehicle-colliaton aceldents that Inwolved fatalities. "ta use is only to idently obfects and to abtain an egtjmate of their frequeney at occurrenee.

The Colorado data provide a llgting of stationary object Invalving tatelitieg. The 1074 Colorado data ctie 209 obfecfo atrutk in 125 ac ciuents rcsulung In 156 fatalities. Multiple impacts are included in these glatsetles: for example, a vehicle may havo struck a guard post on the fight-hand-side of the highwoy; crossed the craflic lanes and olruck the medlan barricr; and recrogged the highway, coming to rest against an cmbankment. Three object calltelons would be resorded for this aceident.

The acerracy of the colorado dat depends upon the isdividual responsible for the iritial accident report. An example of this $\mathrm{ks}$ the reference to an accident where the vohicle struck a "bringe abutment" located in the median. Such an accident is posalbic if the highway has a very wide median, but unlikely. It is probable that the vehlcle struck a large bridge pler. Some accident reporta may contain a detalled deserfption of each object struck, whereas others nuay report only the firdt or lagt abject gtruck. It wos agsumed that these data a re repregentative or cbject collisions and, therefore, this data get was used in the analysis.

The Colorado data have becn divided into five groups:

1. Magsive Objects. Included in this group are bridge abutmentg, tunnel faces, and simllar objects.

2. Substantal Objects. Included in this graup are concrete wing walls. concrete bridge piera, boulders, and other such ltems.

3. tleavy Objecte. Included in this croup are brick walls, median barricrg, guard posti, guard radls, bridge rails, trees, and aimilne objects.

4. Light Objects. Included in this group are signs. curbs, tences. utilty poles, delineator posts, mail boses, and simllar objects.

5. 'Terrain Features. Loluded in unis group are backslopes, omhankmente, ravines, gravel gtockpilos, and gimilar objects. Note that although the mase of any of thege ttoms is large, compared with Massive Objects or Subatantial Dbjects, none will provide severe impact environment for the cargo.

Table D-FV containg a lating of these tive environments ard their frequencies of occurrence. Four of the five eavironments are related to other accident conditions:

1. Mtaggive Objects. Analyzed as a collisian of a shlpment krack into a trafn. 
2. Substantial Objects. Analyzed as a coltision of a shlpment truek Inco a truck.

3.4. Ifeavy Cojects and Termin Features. Analyzed as a colligion of a ghipment truck into a passenger nuto.

5. Light Obfects. I lave the wefght of the object agalgned by the function

$$
w=3400 .
$$

where $x$ is a random variable in the 0-1 tnterval and $W$ ls the weight of the object.

\section{TAIMLA U-IV}

Frequency of Oecurrenes of Cbject Callistons by Croup Lased Cpon 1374 Colorado Stallaties on Ouject Coljsalons which Involved vatall ties

\begin{tabular}{|c|c|c|}
\hline Group & $\begin{array}{l}\text { Number of } \\
\text { Oscurrences }\end{array}$ & $\begin{array}{c}\text { Fraction af } \\
\text { Tottl - }\end{array}$ \\
\hline Magaive Objoets & 4 & 0.0383 \\
\hline Subetantial Obfects & $1 t$ & 0. $086 \mathrm{t}$ \\
\hline Jleavy Objects & 44 & 0.2105 \\
\hline Lisht Objects & 112 & 0.5359 \\
\hline Tertasn Features & 27 & 0.1202 \\
\hline
\end{tabular}

Thig distribution was felt to be overly conservalfve, since it produced more severe environment than the truckftruck collision. Hence, it was further modined to include uhe effect of collision angle. The angle between the object and the tzuck was assumed to vary between zero and $90^{\circ}$. witl all angles having an equal likelihood. The component of the Lruek velocity normal to the object aurface was then employed as the effective bmpact relocity. 
APPENDIXE

IRAIN ACCIOENIS

$E-1,2$ 


\section{Appendix E \\ TRAIN ACCI DENTS}

\section{Frequencies of Train-Accident Iypes}

The probabilities of a derablment, a collielon, or an "other" accident, given a train aceident, were eatimated from the figurca in Table III-I. for these prababilities the notation of Reference 67. where Pr represents a probability and a vertleal line repregenta a condjipn on that probability. was used.

$$
\begin{aligned}
& \text { Pr (deratlment |train accident) }=0.034 \\
& \text { Pr (collision |train accident) }=0.066 \\
& \operatorname{Pr} \text { (other ftrain accident) }=0.100 .
\end{aligned}
$$

Collisions are further broken down into the following calcgorics: ${ }^{28}$ rear-end, head..on. broken-train, side or raking, at railroad crosaings thighway gradc-crossing accidterts arc not included in this categoryl, traine whth carg not in trains, switahing, and thosc not elsewhere classiclable. 29 Data on relative frequencics of these categories for Ireight trains only were obtained from the FRA "T Sheete" (traln-accident roport formg)" for all traln accidents to . Class 1 rajlroad froight trains Juring the months of March and Scptember 1973, a tota: of 1025 accidente. For the purposes of this study, "switehing" and "not elsewhere classifiable" were not ugeful categorica. Thercfore, these accidents were placed, according to accident degeriptions. 1nto appropriate categorieg (e. g. . a gwitching collision that was head-on was placed in the headon category). The resulting estimates of probabilities are given:

$\operatorname{Pr}($ rear-end collision $\mid$ collision $)=0.191$

Pr (head-on collision (colligion) $=0.067$

Pr (broken-train collision $\mid$ collition) $=0.157$

Pr (aide or rakdng colligion / colligion) $=0.315$

Pr $\left(\begin{array}{l}\text { colligiom of train or cars with } \\ \text { cars not in trabng } \mid \text { colligion }\end{array}\right)=0.270$. 
It was also determined from the data that about 36 pereent of the collisions anvolved derailment. Therefore.

Pr (derall |collision $)=0.36$

All theac data are aummarized in the blosk dingram of Fleure E-1.

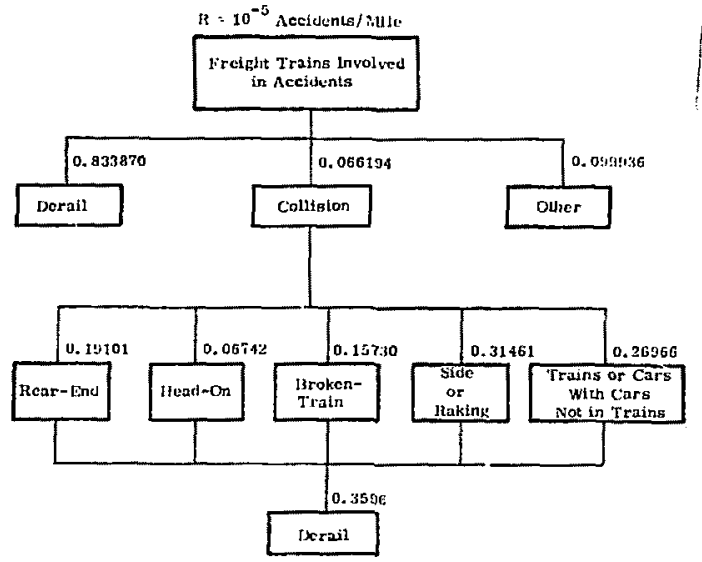

ligure E-1. Class Ifreight-train aceident rateg and frequencies.

\section{Net Velocity Distributions}

From the FRA data, the frajn-speed distribution was found for colligion iccidents. Thts distribation is given in Table EmI. 
TA HLE E-I

UAfier ential and Cumulative Diatributions of Freight Train Specd for Collision Aceidents

\begin{tabular}{|c|c|c|c|}
\hline $\begin{array}{c}\text { Specd } \\
\text { (mph) }\end{array}$ & $\begin{array}{c}\text { Fraction } \\
\text { of Acetdents }\end{array}$ & $\begin{array}{c}\text { Spced } \\
\text { (mph) }\end{array}$ & $\begin{array}{c}\text { Fraction of } \\
\text { Accidents } \\
\text { Below This Speod }\end{array}$ \\
\hline $0-5$ & 0.418 & 5 & 0.416 \\
$5-10$ & 0.214 & 10 & 0.632 \\
$10-15$ & 0.116 & 15 & 0.746 \\
$15-20$ & 0.048 & 20 & 0.796 \\
$20-30$ & 0.097 & 30 & 0.893 \\
$30-40$ & 0.054 & 40 & 0.951 \\
$40-50$ & 0.020 & 50 & 0.980 \\
$50-60$ & 0 & 60 & 0.980 \\
$60-70$ & 0.010 & 70 & 0.990 \\
$70-60$ & 0.010 & 80 & 1.000 \\
\hline
\end{tabular}

From the same dala, the specd dlatribution tras found for derailmems inot including deraliments resulting from collusionsh. Thts distribution is given in Table E-1I.

TA[BL.E F-16"

Dfferental and Cumulative Dfatributions of Froight Train Speed for Darailment Accldents

\begin{tabular}{|c|c|c|c|}
\hline \multirow{2}{*}{\multicolumn{2}{|c|}{ Diferential Oistributios }} & \multicolumn{2}{|c|}{ Cumulative Distrfoution } \\
\hline & & \multirow[b]{2}{*}{$\begin{array}{l}\text { Speed } \\
\text { (mphi! }\end{array}$} & \multirow{2}{*}{$\begin{array}{l}\text { Fraction of } \\
\text { Aceidents } \\
\text { Below This Speed }\end{array}$} \\
\hline $\begin{array}{l}\text { Speed } \\
\text { (mph) }\end{array}$ & $\begin{array}{l}\text { Fraction } \\
\text { of Accidents }\end{array}$ & & \\
\hline $0-5$ & 0.187 & 5 & D. 107 \\
\hline $5-10$ & 0.223 & 10 & $0 .+10$ \\
\hline $10-15$ & 0.174 & 15 & 0.584 \\
\hline $15-20$ & 0.064 & 20 & 0.646 \\
\hline $20-30$ & 0.148 & 30 & 0.796 \\
\hline $30-40$ & 0.082 & 40 & $0.87 \mathrm{~B}$ \\
\hline $40-50$ & 0.075 & 50 & 0.953 \\
\hline $50-60$ & 0. 027 & 60 & 0.980 \\
\hline $60-70$ & 0.010 & 70 & 0.990 \\
\hline $70-40$ & 0.010 & 80 & 1.000 \\
\hline
\end{tabular}


The broken-urain colligton ls a epcoial ease of the colligion aceidont. The following is a sequence of events leading to this accident:

1. At some point in the train the cara uncouple. The motive power on the leading cars drawg them away from the tralling cers.

2. Automatic braklng gystoma are acdvated by the opening of adr Ine connection at the point of aeparatian.

3. The leading cars glow more quickly thar the tralling cars, then the tralling cers eatch up to the leading cars and collide with them.

The reiative velocity at the time of the collsion is controlled by effectiveness or braking in each gection of the train. It id assumed that its magnitude is low and that the prinary aceidenl effects pec caused by deraliment of earg subsequent to the collision. On the aforementioned " $T$ " forms. the speed at which the break occurred was all that was reported for the broken-train collisions. This digtribution, with "unknowns" arbitrarlly placed ty the 70- 10 80-mph category, is given in Table E-111. Nuthough this digtribution is not alatistically glgalfiesnt inasmuch ag it repregents oaly 12 accidents, it does represent the best estimate available.

\section{TABLE E-III}

Vistribution of Train Specd at Time of Break for leoker-Train Aecidents

\begin{tabular}{|c|c|}
\hline $\begin{array}{c}\text { Spes } \\
\text { (mph) }\end{array}$ & $\begin{array}{c}\text { Prraction of } \\
\text { Accidents }\end{array}$ \\
\hline $0-10$ & 0 \\
$10-15$ & 0.083 \\
$15-20$ & 0.083 \\
$20-30$ & 0.250 \\
$30-40$ & 0.250 \\
$40-50$ & 0.167 \\
$50-60$ & 0 \\
$60-70$ & 0.083 \\
$70-80$ & 0.083 \\
\hline
\end{tabular}

\section{Typical Train Definition}

For thls atudy, It is necegency to dellne a "typical" Irelght traln according to average figures for mubers of cars, types of carg, and tractiong of cars laded. ${ }^{20}$ Statisucs from Reference 67 result in the typical Ereight trasin assumed throughout this atudy (aee Table E-IV). 
TABLE E-IV

Defindtion of Typical Freight Train as lised in This Study

\begin{tabular}{|l|c|c|c|}
\hline \multicolumn{1}{|c|}{$\begin{array}{c}\text { Type of } \\
\text { Car }\end{array}$} & $\begin{array}{c}\text { Number } \\
\text { Full }\end{array}$ & Other & $\begin{array}{c}\text { Number } \\
\text { Euply }\end{array}$ \\
\hline Lacomotive & & 3 & \\
Fialn Boxear & 7 & & 6 \\
Equipped Boxcar & 4 & & 3 \\
Gondola & 4 & & 3 \\
Open floppor & $B$ & & 6 \\
Covered Hopper & 4 & & 3 \\
Flat Car & 3 & & 2 \\
Rerrigerator Car & 2 & & 2 \\
Tank Car & 4 & & 3 \\
Oher Car & 1 & & 1 \\
Caboose & & 1 & \\
\hline
\end{tabular}

\section{Accident Rate per Car Mile}

The environmente to be deseribed herc are those to which an individual railear wll be subjected, given a train aceident. Cas damage due to impact in accidents other than collisjons or deraiments was assumed negligible. It is believed that these accidents primarily involved casualties, fire, and/or minor equipment damage.

The average number of ears involved in therailment accidents appears to increasc rapiclly with derailment velocity, as docs the number of cars affected by collsion acefdents. There are also indications from the avallable data that the number of cars involved in deraifments increases as train length increases. ${ }^{6 B}$ woth these factors were considered in deraiment and colligior models.

\section{Preaccident Train Speed}

To achleve the continuoug distribution required for the enalytical treatment. the train speed data shown in Tables E-I and E-11 vere fitted wth Webul distribution curve of the form

$$
F(v)=1-e^{-\frac{v}{\beta}} .
$$


where

$\checkmark$ is the preaceldent traln velocity*

$x$ ta a ragdam number galected from a uniform dlatribut on in the 0-1 interval.

$\alpha$ and $\beta$ ace constante.

Figure D-2 is a plot of the data contnined in Table E-1 and the continuous speed distribution used in the analyals for collision aceddents. Figure E-3 ts a plot of the data contalned in Tabie E-II and the contlnuous opeed distribution used in the derailment analygig. In cach case the vaites of $\alpha$ and $\beta$ were selected to obtain a reasonable curve fit to the diecrete data sets. The spect distribution for broken-trafn accldent. Table E-CI, was approdmated by a piecewise linear function. Figure E 4 is a plot of the diBcrete wha and the pleceutac linear furction.

$$
\begin{aligned}
& \text { — Heference I Iata } \\
& -{ }^{\prime}(\mathrm{x})=1-\exp -\left\{\frac{\mathrm{x}}{10 .\}^{0.7405}}\right.
\end{aligned}
$$

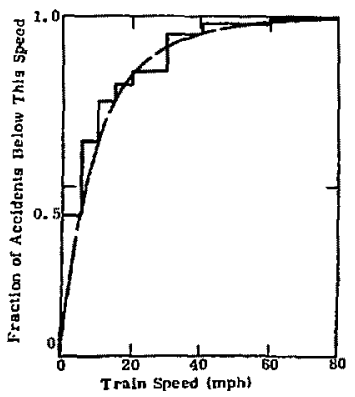

Figure E-2. Curwlntive Hatrlbution of fright train speeds for collition accidents. 


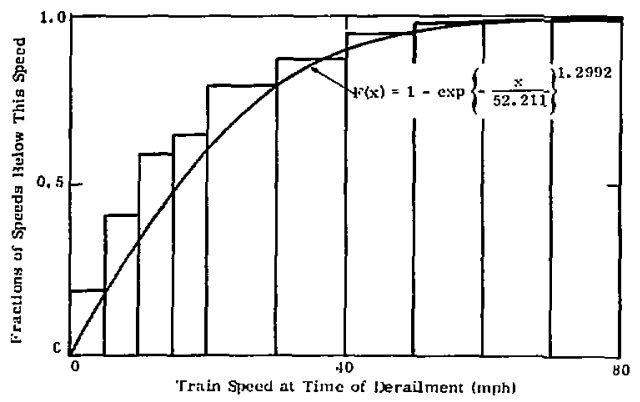

Jigure E-3. Cumulative distribution of freight train speeds for derallment accidents.

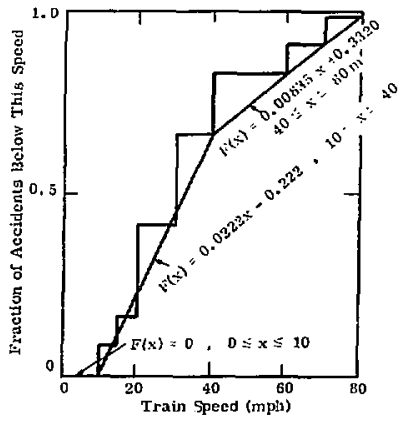

Figure E-4. Distribution af train speeds at times of break, broken-train accidente. 


\section{Car-Derailment Models}

Three different models were formulhted to determine the number of cara that would be involved In a deradment accident, given that sueh an accident oceutred. A number of factor $\mathrm{s}^{68,69}$ appear to influence the number of cars that will be involved in any given derallment:

1. Train Speed. The number of caro deralled per accldent appears to increase significantly witl trats speed.

2. Train Length. The number of cara derailed per accidens appears to increase significantly as the number of cars approaching the derailment point tncreases.

3. Train Compoattion. The effect of a mixed train compased of cere of substantially different lengthe and woights affects the derailment panern.

4. Car characteristics. Car length and weight appear to affect the number of cars derailed in a givon aceident.

5. Ground Friction. Ground friction affects the rate at which the Jerailed cars slow to a stop.

6. Braking. Upon derailment, the brakes are automaticaly applicd to all cars. This affects the rate at which cara remaining on the tracke suow to a stop.

Of these alx fioms, only traln speed at the time of deratument was considered as a bisls for sonstruction of each derailment model. The efiect of train iength was considered scparately and is discussed belon. The effects of the train composition and individual car characteristica wero not considered in deter miring the number of cars derailed, given a derailment geciuent. In the determination of the car velocily following derailment, however. boun ground friction and braking were consithered.

Derallment Model 1 was Laken directly from Reference 1 and ja identical to that uscd in determining small-package emvironments (Figure E-5). Deraitment Alodel 2 was designed to give a contimuously varying distribution of cars dorailed as a function of derailment specd. The relatiun wes establiahed go that the lour cages considering apeed teprendence ${ }^{68}$ would be compatible with the chosen function. In Figure E-6, where Derailment Model 2 is shown, the four points of correspondence are indlicated by gmall circles. 


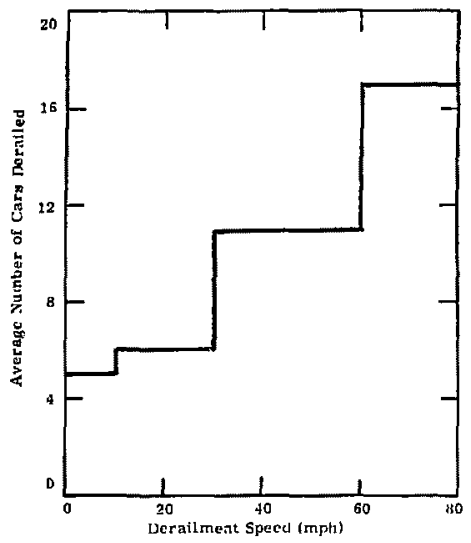

Figure E-5

Average number of cara deralled as a function of trati speed at lime of derailment tholel 1 ).

Figure E-6

A verage number of cars derailed as a function of train speed at time of deratiment (Model 2).

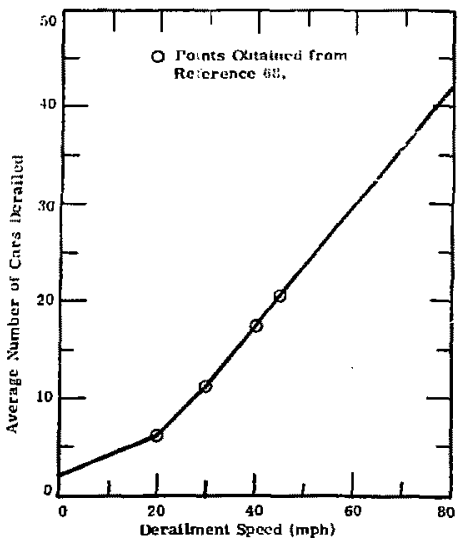


An additional item of data dealing with the speed dependence of the number of cars derailed is avallable from Reference 69 . In this case the average number of cars damaged as a result of derallment is reported. The average sumber of cars damaged versus derallment spect, ${ }^{69}$ Identified as Derallment Model 3. Is shown in Figure E-7. To aid In comparlson of the three different derallment models, the expectcd number of cars that will derail is plotted as a function of preacctdent traln epeed in Figure E-8.

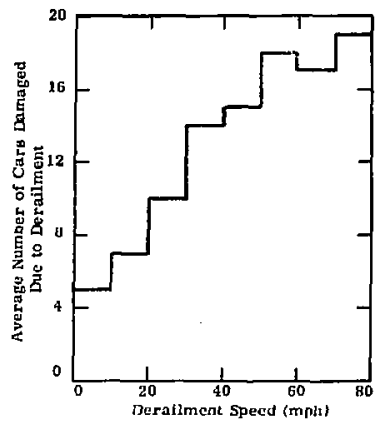

Figure E-7. Average etumber of cars damaged per accldent (Modol 3 ).

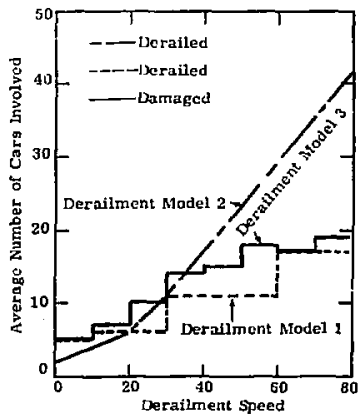

Figure E-8. Comparison of Deraflment Modela 1, 2, and 3. 


\section{Car-Collision Models}

Two colligton models trere consldered. In Model $t$ al cars th the train were arsumed to be affected by a head-on or rear-end collelon." In Model 2 the average number of cars damaged by the callsolom were congidered. 69 In bath models the broken-traln collision was handled as a

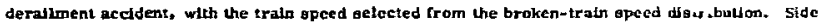
or rakding collighans and colusions with cars not in ualn were bandled as head-on or rear-end collistong. In both mojels there were possibilties of the car escaping involvement in the collision bechuse of the method of evajuation of broken-train regults.

The diatribution used in Alodel 2 is shown in Figure E-9. As stated above, all cars are assumed to be involved in the accident in Miglel I.

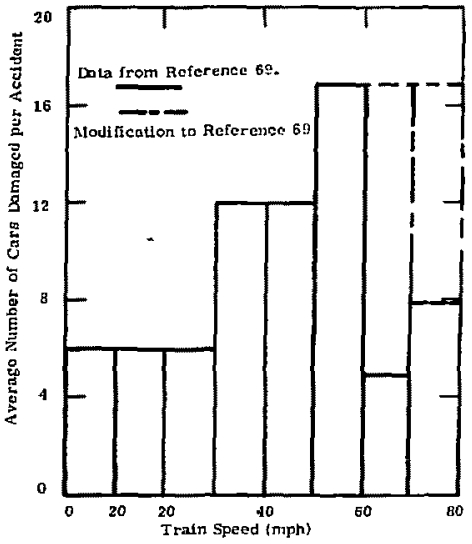

Figure E-ㅇ. Accidents involving colligion of any kdnd (Model 2). 


\section{Train-Length Effect}

The length of the train affects the expected number of der alled ears lf all other factors are

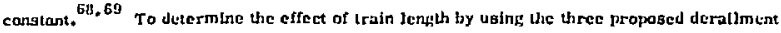
models, the numbers of ears in the train were taried between 20 and 200 in increments of 20. 'The probability that the thipment car was in the deralled string of care was colculated and recorded. Calculations were made by usc or a Monte carlo procesy and bie derallinent analysis for cach model and cach train length. The results are preserited in ligure $1:-10$. It can be acen that the probabulty of a gelected car lreint involverl in a dorallment dropg rapidly as the length of tiu train to increased. Ir robabllity based on a typteal troin of 60 cars will be congervative if the GC car regults are applied to dongcr tralns. No inlormation whith would permit the direct determination of a deralment model that is bod, length- and spect-ilopendent is cur rently available.

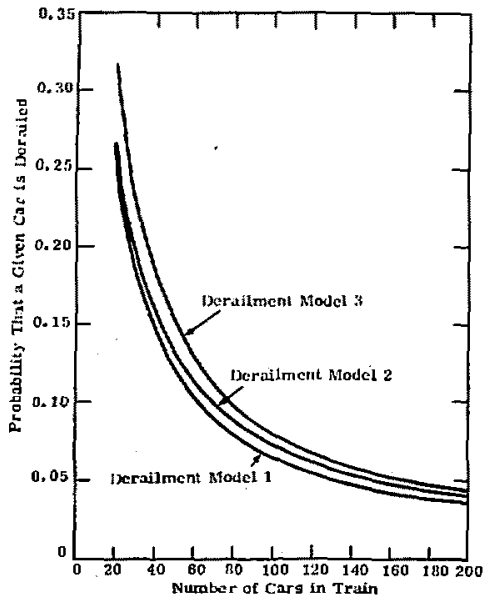

Figure E-10. Probabllity that a given car if derailed, given that the traln consista of N cars, three locobrutives, and a caboose. 


\section{REFERENCES}

1. I. h. Clarke et al., Severitice of Trangportation Accidents. Sl_Am74-0001, Sandia labort. torkss. Altbuquerque, NAt, July $107 \mathrm{~b}$.

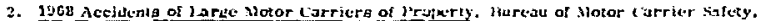

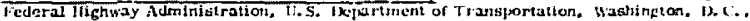
inecomber $136 t$.

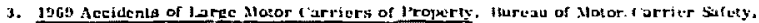

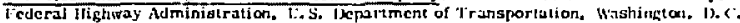
Iecember 1970 .

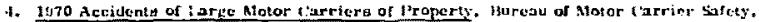

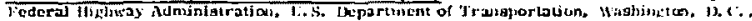
liardi 1972.

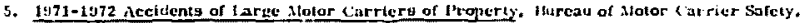

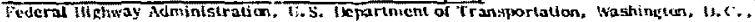
lay 1:174.

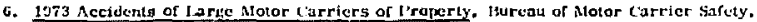

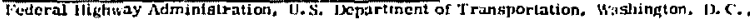
July 1975.

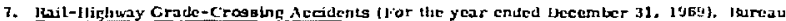

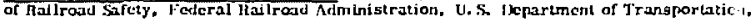
Washington. 1). $\therefore$

3. Hafl-Ilighway Grade-Crosaing A ceidents fFor Uie yesr ended irecember 31, 1070), threau of thilroat safety. Federal inalroad Kuministration, (1.5 Jepurtment of Transportation, Washington, 1). C:

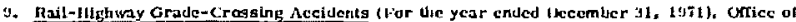
Sacty. Federal hajl v. C.

10. Rail-IIghtway Grade-Crogsing Accidents (100 the year cnded Hecember 31. 1072), Orfice of Sofcts. Federal hafiroad Administration. L. S* Defartment of Trangportation, Washingan. D. C.

11. 1969 Analysis of Aceident Reports Lnvolving Firc. U.S. Jupartment of Transportation, Federal Ifightay Administration, Bureau of Motor Carrier Safety.

12. 1971 Andygie of Acciden Reparts Involving Mre, U.S. Iepartment of Transportation. Federal ilighway Administration, Bureau of thotor Carrice Safety, March 197's.

13. EL E. lader, "Ileat Trangfer in Liquid Ifydracarton Fucl Hres," Chemical preinecring Propress Symposium Serjes, vol. 61, Xe. 58, 1965, p. $76+0$.

14. W. de L. M. Messenger. The Transport of Rudjoactive Materials, United Kingdom Atomíc Fiergy Authoeity, January 1962 .

I5. L. I. Russell and J. A. Canfield, "Experimental Meagurement of tleat Tranaler to a Cylinder Immersed in a Large Aviation Fuel Fre," Trans, ASME, Sericg C. J. Heat Transfer. 05. August 1973, pp. 357-407. 


\section{REFERENCES (cont.)}

16. D. Gross, "Bxperiments on the Burning of Crogs Files of Wopd, "5. Eegearch National Bureau of Standarde 85C. No. 2, 1882, pp. 99-105.

17. H. W. Emmons and T. Shen, "FJre Spread in Paper Arrayg." 13th Sympogium (International con Combustion. The Combugtion Instifute, 1971, PP. 917-827.

18. D. W. Larzan, Unpubllabed Data, Sandia Laboratomes, Albuquerque, New MLdco.

19. Charring Rates of Selected Woodg, U. S. Foregt Servicc Rebearch Paper FIL 69, Madison, Wigcongin, Apru 1067.

20. Revtew of Information Related to the Chayriref Rate of Wobd, L. S. Faregt Servec Rescarch Note FPL-0145. Madison, Wisconsin, Nuvernber $196 \overline{5}$

21. P. L. Blackehear, Jr., and A. M. Kanury, "Fleat and Mass Trangfer to, From, and Within Cellulosic Solidg Burning in Alr." Tenth Sympisium (International) on Combugum, The

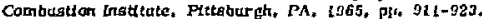

a2. I969 Centenial Editon - The World Almanac and Book of Facts, Luman II. Long. cd, Newspaper Enterprlge Aseociation. Inc. p. 438.

23. Ibid, p, 573.

24. Waterborne Commerce of the Undted States, Parts 1-5 Calendar Year 1972, Department of the Army Corpa of Enginects.

25. Regulations for the Safe Trangport of Rudioactive Materlala, 1AEA Safety Series No. 6. Vicnus, Austria, 1067, p. 1t.

26. Code of Federal Regulationg, Part 225, Section 225.21, October 1, 1974.

27. Accident Balletin No. 141, Summary and Analygls of Accidents on Rallroads in the Lnited

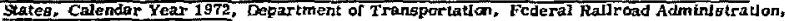
Burequ of Rallroad Safety.

28. Code of Federal Megulationg, Part 225, Sectian 225, 22, Octcber 1, 1973,

29. Yearbook of Faitroad Facts, 1973 edisom. Economics and Finance Department; Asgociation of American Rafliroadg, L. C. Card No. Abb-7305.

30. Summary and Anglysie of Accidenta on Rallroade in the United Stateg, Department of Transportation. Federal Raflroad Admisistration, Bureau of Radroad Safety, publiahed angually.

31. "Report of Fire Logseg for Calendar Year 1872, "National Fire Protection Asgoriatlon--Mailroad Section, private communication wh Jabn Otosch. F1re Record Department, March 1974.

32. Rall Accldent Reparts (Form $T$ ), maintalned by Federal Rallrosd Adontrletration.

3's. R. K, Clarke, J. T. Foley, W, F, Hartman, and D. W. Laraon, Severittes af Trangpartallan Accidents, Vol. I - Alreraft, SLA-74-0001, Sandls Laboratorle日, Juy 1BTE.

34. R. K. Clarke, J. T. Foley, W. F. Hertman, and D. W. Larson, Severitieg or Tranepartation Accidents, Yol. II - Motor Carrier, SLA-74-0001, Sandia Laboratories, July 1976.

35. Car and Locomotre Focyclopedis, Compled tor the Asgociation of Amerien Failroady, smmong-Boardman Publiaking Co., New York, t970. 


\section{REFERENCES (cont.)}

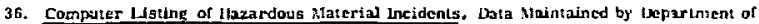
Trangportation, Office of lizzardous Materids, July 1973.

37. Rajlroad Accident Jepor: - Derailmcit of hlissouri lactle Jibroad Cunmany*s Train DA at liouston, Texag, October 19, 1971. FTSI-ItAR-72-6, sational Transportation Safety Board, December 13, 1972 .

31. Raluroad Accident Report - Chicago, Iurlington and Quincy MallrooJ Company tran 64 and Train BQ4 Derallment and Collision with Tank Car Ixpiogion at Crete, Nebraska.

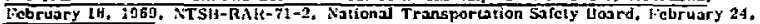
157!.

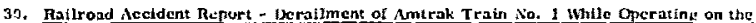

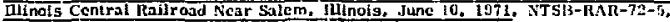
Nationd Tringportotion Sifety Harit, Augest 30, 1972.

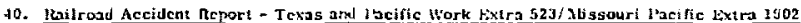

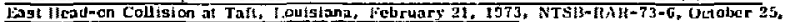
1157.

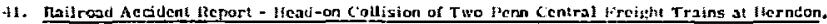

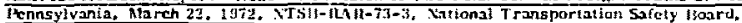
Harch $:$ i, 107j,

52. E. is Abano and P" Scide. "Itifurcation of linfs linder Coacentrated Central lifected loads," JAll, Junc 1973 , p. i5?.

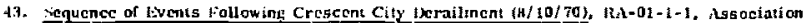
of nmeriear thilrasts. Chicafo tiegeareh Center.

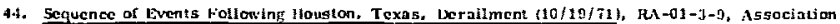
of American habirools, Gieago, hescarch Center.

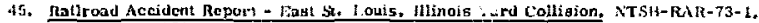
Janualy 22, 1072.

46. Railroad Accident Report - Hazurdous Natcrials Accidene in the Tailroad Yard of the

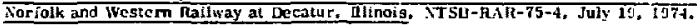

47. Raltroad Accident Report - Ilazardous Materials Accident at the Southen: Patic Transportation Company's Engichood Yard in Lo ston, Texas, NTSt-Rhih-75-7. Septomber 21. 1974.

48. Railsaad Accident Report - Derailment and Subgeguent Hurning of Uelaware and lfudgon

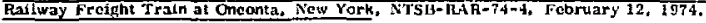

19. E. U. Hagen. Probabilistic Approach to Degign, John Wilcy and Sons. New York, 1968.

50. Code of Federal Regulationg; Tart 71, Tille 10, Chapter 1, April 30, 1975.

51. Specliteations for Design Fabricalion and Construction of Freight Carg, Assoctation of American Jallroads, Chicago, Dlinoig, 1964.

52. Summary of Accidente Invegtigated by the Federal Railroad Administration in Fiscal Year 1071-1072, Deparument of Trausportation. Federal Rall road Adulnistration.

53. Summery of Ruptured Tank Cary lnvolved In Accidente, RA-01-2-7, Association of American Faltroads, Revised July 1, 1972, Chicago, IL 


\section{REFERENCE5 (cont)}

54. The Registance of Varjous Metulte Matcrials to Pertoration by Steel Fragments, Projeet Thur Technieal Report Sid. 47, Balltgkic Analyais Loboratory, Baltimore, Maryland, Aprll I067.

55. J. T. Folcy et al. Truck Route Survey tor LMFBR Spent Fuel shipplng liazard Anatysis. SAND76-0313, Sandia Laborataries, Albuquerque, NM, November 1976.

56. W. F. Ilartman et al., Sultst ical Deserlption of Ilezvy Truck Aecidents on Repregentalive Segments of Interslate lighway, SnN075-0409, Sandia Laboratories, Albuquerque, NM!. November 1076 ,

57. F. Loimkuhler. Trucking of Radloactive Materials, 'The Johns llopkins Press, faltimore, MID, 2963.

56, D. E. Pattergon and $A$. Mehn, A Summary of (neidente lnuolung USAEC Shipments of Radioactive Material, Iriviston of Cprational Safety. AEC. TlD-1G7GA (Suppl. i). Kovember $[$ TB].

59. A Summary of Incidents Involving USAEC Shipments of Riudioactive Matcrials, 1963-1964, Évision of Gperattonal Safcty (AEC). Induslr!al Safely and Fire Protection Eranch, washington, D, C.. TID-16764 (Suppl. 2). April 1965.

BO. R. E. Scott et al. Statistical tnalysis of Truck Accldent Involvemenis. The Liniversity of Michigan lif ghway Rescarch Institute, Nns Arbor, Ril, Docember 1971.

61. Statistical Abstract of the United States 1974, is reau of Uae Census, U. 5. Department of Commerce, 95th Bdition, Washington, D. C., 1374.

62. Conversation between J. T. Foley and C. A. Davidson, Sandia Laboratoricg, Division 1285, and Fugsell KIdwell. Bureau of Motor Carcier Safety, May 1976.

63. NADA Official Used Car Guide. Vol, 44, No. 1. National Automobile Dealera Lied Car Gulde Co.: McLean, VA. January 1977.

64. State Size, Weight, and Speed Maxlmums for Trucks and Truek Trailers, Mockwell-Standard Campany, Detroit, Mi* nugust 1071.

65. A. W, Denila, Analytical Investlgation of a Grade-Crosging Accident Between a Railroad Train and a spent Reactor Fucl Cask, SAND74-031?, Sandia Laboratories, Albuquerque, NM. Jaluary 1975 .

66. Fatal Traffic Accident Summary, State of Colorado, 1074.

67. K. A. Brownlee, Slatigtical Theory and Methodology in Sclence and Pegineering. Secand Edition, John Wiley and Sons, New York, 1965.

68. Pallrogd Tank Car Safely Research and Test Project, Phase 08, Report on Computer Derat]ment Study, FA-08-1-12, Asgociation of American thailroads, Chicago, Rescarch Center, February 17, 1972.

69. L* F. Melgg, Stucly of Freight Train Accidents Experienced by Class I Raflways, SCR-111, T1D-4500, Sandia Laboratories, Albuquerque, NM, Auguat 1050. 